\title{
Establishing tephrostratigraphic frameworks to aid the study of abrupt climatic and glacial transitions: a case study of the Last Glacial-Interglacial Transition in the British Isles (c. 16-8 ka $B P)$
}

Article

Accepted Version

Creative Commons: Attribution-Noncommercial-No Derivative Works 4.0

Timms, R. G. O., Matthews, I. P., Lowe, J. J., Palmer, A. P., Weston, D. J., MacLeod, A. and Blockley, S. P. E. (2019) Establishing tephrostratigraphic frameworks to aid the study of abrupt climatic and glacial transitions: a case study of the Last Glacial-Interglacial Transition in the British Isles (c. 16-8 ka BP). Quaternary Science Reviews, 192. pp. 34-64. ISSN 02773791 doi: https://doi.org/10.1016/j.earscirev.2019.01.003 Available at https://centaur.reading.ac.uk/86407/

It is advisable to refer to the publisher's version if you intend to cite from the work. See Guidance on citing.

To link to this article DOI: http://dx.doi.org/10.1016/j.earscirev.2019.01.003

Publisher: Elsevier

All outputs in CentAUR are protected by Intellectual Property Rights law, 
including copyright law. Copyright and IPR is retained by the creators or other copyright holders. Terms and conditions for use of this material are defined in the End User Agreement.

\section{www.reading.ac.uk/centaur}

\section{CentAUR}

Central Archive at the University of Reading

Reading's research outputs online 


\section{Establishing tephrostratigraphic frameworks to aid the study of abrupt climatic and glacial transitions: a case study of the Last Glacial-Interglacial Transition in the} British Isles (c. 16-8 ka BP)

Rhys G.O. Timms ${ }^{a^{*}}$, lan P. Matthews ${ }^{a}$, J. John. Lowe ${ }^{a}$, Adrian P. Palmer ${ }^{a}$, Dorothy J. Weston ${ }^{\mathrm{a}}$, Alison MacLeod ${ }^{\mathrm{b}}$, Simon P.E. Blockley ${ }^{\mathrm{a}}$

aCentre for Quaternary Research, Department of Geography, Royal Holloway University of London, Egham, Surrey, UK

bDepartment of Geography and Environmental Science, University of Reading, Reading, UK.

*Corresponding author

\section{Abstract}

Distally dispersed tephra layers have become an important tool in the investigation of palaeoenvironmental and archaeological records across the globe. They offer possibilities for the synchronisation and improved chronological control in those records to which they can be traced and hence contribute to an improved understanding of the pattern and timing of environmental and archaeological change during periods of rapid climatic adjustment. However, their use as robust isochronous markers for synchronising records is frequently compromised by uncertainties relating to stratigraphical context, precise chronology and chemical composition. Here we collate and review the tephrostratigraphical information dating to the Last Glacial-Interglacial Transition (LGIT; c. 16-8 ka BP) in the British Isles based on published and unpublished records obtained from 54 sites. Based on details of their stratigraphic position, chronology and chemical composition, we propose that 26 individual eruption events may be represented in this collective record which spans the LGIT. The great majority of these eruptives can be traced in origin to Iceland, but we also report on the recent discoveries of ultra-distal tephra from the North American Cascades range, including for the first time the Mount St Helens J Tephra at a site in southern Ireland. These particular ultra-distal discoveries have resulted from a reinterpretation of older data, demonstrating the potential importance of 'unknown' analyses in older tephra datasets. The outcome of this review is a comprehensive but provisional tephrostratigraphic framework for the LGIT in the British Isles, which helps to focus future research on parts of the scheme that are in need of further development or testing. The results, therefore, make an important contribution to the wider European tephrostratigraphic framework, while adding new discoveries of transcontinental isochronous tephra markers. 
Keywords: Volcanic Ash layers, Cryptotephra, Tephrochronology, Europe, late Pleistocene, Holocene

\section{Introduction}

43

In the last three decades the adoption of (crypto-)tephrochronology as a technique for the dating and correlation of Quaternary environmental records has greatly increased (Lowe, 2008, 2011; Davies, 2015; Lane et al., 2017). This heightened interest, particularly in distal environments, reflects a wider appreciation of the unique combination of advantages that volcanic ash layers offer: (i) many have been shown to serve as precise isochrons that provide independent tests of stratigraphic correlations based on other approaches (see Davies et al., 2012; Blockley et al., 2014); (ii) where they can be dated directly, the results provide independent tests of age models based on alternative methods (e.g. Bourne et al., 2015a; Matthews et al., 2015); and (iii) where there is accordance between tephra-based and independently-derived age models, integration of the collective results leads to betterresolved chronologies (e.g. Blockley et al., 2008; Matthews et al., 2011; Lowe et al., 2013).

For the above applications to yield reliable results, however, secure chemical identification and robust dating of individual tephra layers are of paramount importance, but achieving these aims is frequently confounded by a number of practical obstructions. These include the difficulty of differentiating individual tephra layers that originate from volcanic sources with near-identical chemical signatures (e.g. Bourne et al., 2010; Bourne et al. 2015b; Lowe, D. et al., 2017), problems with distinguishing primary fall deposits from secondary reworked material (e.g. Guðmundsdóttir et al., 2011; Lowe, 2011; Griggs et al., 2015; Wulf et al., 2018), and the need for more robust universal standardisation procedures for the chemical fingerprinting of volcanic material (Pearce et al., 2014; Tomlinson et al., 2015; Lowe, D. et al., 2017). In an effort to overcome, or at least minimise, the effects of these complications, tephrochronologists are progressively developing regional schemes that integrate the stratigraphic, chemical and chronological information for all individual tephra layers within specified time intervals. These regionally focused initiatives aim to identify those tephra layers that best serve as reliable isochrons and the geographical ranges (or 'footprints') over which they can be traced; collectively these constitute a tephrochronological framework or 'lattice' (Lowe et al., 2015). Examples of Late Quaternary regional frameworks that are under construction include those for Europe and the Mediterranean (Blockley et al., 2014; Bronk Ramsey et al., 2015; Wulf et al., 2018), Greenland (Abbott and Davies, 2012; Bourne et al., 
(Davies et al., 2016; Mackay et al., 2016; Pyne-O'Donnell et al., 2016), the Kamchatsky Peninsula (Ponomareva et al., 2017), Japan and East Asia (Moriwakia et al., 2016; McLean et al., 2018), southern Patagonia (Wastegård et al., 2013; Fontijn et al., 2016), East Africa (Blegen et al., 2015; Lane et al., 2018), New Zealand (Lowe, D. et al., 2008) and East Antarctica (Narcisi et al., 2010). Ultimately it may prove possible to link these regional frameworks using common 'ultra-distal' tephra isochrons which, if successful, would provide important markers for establishing or testing the alignment of palaeoenvironmental and archaeological records at the continental and perhaps even global scale (Lane et al., 2017;

83 Plunkett and Pilcher, 2018).

In Europe tephra isochrons have proved especially valuable for highlighting the timetransgressive nature of past environmental changes during the Last Termination and early Holocene (also referred to as the Last Glacial-Interglacial Transition (LGIT), c. 16-8 ka BP), particularly when associated with records that can be resolved at sub-centennial timescales (e.g. Lane et al., 2013; Wulf et al., 2013; Rach et al., 2014). The framework for this region currently includes approximately 60 different tephra layers, sourced primarily from Icelandic, Eifel (Germany) and Italian volcanic sources (Figure 1), with overlapping envelopes extending from Greenland (recorded in ice cores) to southern and eastern Europe (Davies et al., 2002; Blockley et al., 2014; Bronk Ramsey et al., 2015; Lowe et al., 2015). Collectively, they provide the potential for assessing environmental shifts across Europe over a refined timescale and with a greater precision than has previously been attainable. However, the majority of these tephra 'linkages' are based on the detection and analysis of glass shards forming cryptotephra deposits, which can prove particularly challenging with respect to their chemical analysis, precise dating and stratigraphic integrity.

Here, we evaluate the extent to which the aforementioned problems impact on the LGIT tephrostratigraphic record of the British Isles, which afford a suitable case study for this avenue of research for the following reasons: (i) the region is one of the most intensively studied for cryptotephra deposition anywhere in the world; (ii) a large number of cryptotephra layers have been traced across different depositional contexts (palaeoenvironmental and archaeological) over the course of the last 30 years; (iii) many of the sites have been forensically examined for cryptotephra content either through the analysis of multiple sequences at a single site, or by the high-resolution contiguous sampling of an individual record; (iv) the tephrostratigraphical sequences can be compared within a well-established bio- and lithostratigraphical framework that spans the LGIT (see Walker and Lowe, 2017); and $(v)$ the British Isles are well positioned with respect to the dominant wind systems that 
transport distal ash from volcanic centres in the Northern Hemisphere, as a number of sites register multiple ashfall events within the comparatively short interval of the LGIT.

The main aim of this paper, therefore, is to provide a critical overview of the current potential for building a robust tephrostratigraphical framework for the British Isles spanning the LGIT. In the sections which follow we focus on (i) those tephra layers that can confidently be assigned to the same eruption events and hence represent isochronous stratigraphic markers; (ii) examples of proposed tephra correlations for which the evidence is presently less certain, with proposals for more stringent tests of their credibility; and (iii) general recommendations for advancing the construction of tephrostratigraphical frameworks in distal and ultra-distal locations, where the available evidence consists entirely or predominantly of cryptotephra deposits.

\section{Background: distal tephras detected in the British Isles}

The development of tephrochronology in Northern Europe can be traced to the seminal works of (inter alia) Pórarinsson (1944), Noe-Nygaard (1951) and Persson (1966), who first demonstrated the potential of Icelandic tephras to serve as isochronous markers in Scandinavia. However, it wasn't until the late 1980s and early 1990s, following methodological advances facilitating the routine identification and chemical characterisation of invisible micro- or cryptotephra horizons, that the potential for (crypto-)tephrochronology in distal locations was fully realised. In the British Isles, this potential was first demonstrated for sites in mainland Scotland by Dugmore (1989), Blackford et al. (1992), Dugmore and Newton (1992), extended to the Orkney and Shetland Isles by Bunting (1994) and Bennett et al. (1992) and to Northern Ireland by Pilcher and Hall (1992). All of those studies were focused on the investigation of Holocene sediments, from which the tephras could be detected by combusting or dissolving the organic-rich or carbonate-rich substrate and analysing the latent residues (cf. Gehrels et al., 2008). This procedure was not suitable, however, for the processing of pre-Holocene sediments, because of their comparatively high minerogenic content. It was therefore not until the application and further development of a density-controlled sediment flotation procedure that the detection of cryptotephra layers in Lateglacial sequences was made possible (Eden et al., 1992; Lowe and Turney, 1997; Turney, 1998a; Blockley et al., 2005). The success of this relatively straightforward and inexpensive laboratory method led to a rapid proliferation of the number of scientists engaged in cryptotephra research, significantly increasing the number of tephras identified across the British Isles and Europe, whilst simultaneously revising the eruptive history and 
dispersal range of many volcanic centres at the global scale (e.g. Swindles et al., 2011; Lane et al., 2017; Pilcher and Plunkett, 2018).

In the British Isles, the Quaternary tephrostratigraphic record is largely confined to the period post-19 ka, because much of the region was still covered by the Late Devensian (last) ice sheet until that time, while the ice did not retreat from Scotland and northern Ireland (where most of the cryptotephra discoveries have been made) until after c. 16 ka (Clark et al., 2012; Hughes et al., 2016). A brief and spatially-restricted resurgence of glaciers, locally termed the Loch Lomond Readvance and dating approximately to the Younger Dryas cold phase, occurred between c. 12.9 and $11.7 \mathrm{ka}$, which was followed by rapid and complete deglaciation of the British Isles during the early Holocene (Ballantyne 2010, 2012; Walker and Lowe, 2017; Bickerdike et al., 2018). The receding ice from these glacial episodes uncovered large lake basins and many small kettle depressions that formed within abandoned glacial deposits; these have subsequently infilled with lake sediments over millennia, serving as archives for the accumulation of volcanic ash, whether delivered directly by fallout from ash clouds, or washed in from surrounding catchment slopes. At the time of writing, tephrostratigraphic investigations have been conducted on sediments dating to the LGIT in 54 individual lake basins in the British Isles (e.g. Bennett et al., 1992; Bunting, 1994; Lowe and Turney, 1997; Wastegård et al., 2000; Davies et al., 2001; Bondevik et al., 2005; Ranner et al., 2005; Turney et al., 2006; Pyne-O'Donnell, 2007; MacLeod 2008; Matthews et al., 2011; MacLeod et al., 2015; Jones et al., 2017; Kelly et al., 2017; Timms et al., 2017, 2018; Housely et al., 2018; Figure 2) and it is this evidence that is reviewed in this paper. The majority of the individual tephra layers have been traced in origin to volcanic centres in Iceland, which reflects the position of the British Isles with respect to the dominant cyclonic circulation in the North Atlantic, and the westerly storm tracks that it promotes. Ejection of ash clouds into these systems means that the British Isles not only lay within the likely dispersal envelope of a large proportion of eruptions derived from the Icelandic province, but are also well within the dispersal envelope of 'ultra-distal' ashes derived from volcanic centres across the Northern Hemisphere (Jensen et al., 2014; Plunkett and Pilcher, 2018). Whilst the occurrence of ultra-distal ashes has been documented for Holocene sequences across Europe (e.g. Van der Bilt et al., 2017; Watson et al., 2017; Plunkett and Pilcher, 2018), the occurrence of ultra-distal ashes in records spanning the LGIT are a more recent discovery and hence are less well researched, but nevertheless promise exciting opportunities in the development of trans-continental tephra frameworks (Pyne-O'Donnell and Jensen, 2018). 


\subsection{The nature of the tephra record}

187

The primary data that underpin tephrostratigraphic frameworks are robust chemical signatures of the glass, crystal, pumice and lithic phases of an eruption, combined with precise stratigraphic superposition, supported where possible, by independent dating of individual tephra layers. In volcanically distal environments such as the British Isles, however, the precise characterisation and correlation of tephra horizons presents a significant technical challenge. The absence of crystal, pumice and lithic phases, owing to the unfavourable transport of these components over longer distances, means that greater emphasis is placed on the far travelled glass shard component. However, low glass shard concentrations and small shard sizes in the distal environment hinder the application of standard lithological methods, e.g. measures of physical properties such as grain-size, colour, bed thickness etc., which are usually only feasible if the ash layer remains visible. With few exceptions, tephras detected in the British Isles are 'crypto' in nature, which means that the glass shards must first be extracted from their host sediments before characterisation and correlation procedures can be adopted (see Lowe and Hunt, 2001). Inevitably, because the data contributing to the British tephrostratigraphic framework have been accrued over a period of approximately 25 years (see references in Supplementary Table S1), sampling and analytical procedures have evolved and hence are not (at least in raw format) fully standardised. Consequently, data comparisons should take into consideration the following potential inconsistencies and limitations. Firstly, laboratory procedures for cryptotephra (glass shard) extraction and separation have been progressively refined. Early studies relied on destructive chemical procedures to eliminate non-tephra particulate matter, but these were later shown to distort the chemical signatures of certain compositions of tephra (Pollard et al., 2003; Blockley et al., 2005); as a result, the density separation procedure of Turney (1998a) was modified to eliminate the need for chemical digestion. Secondly, sieve sizes of a greater aperture range are now employed as routine, usually $15-125 \mu \mathrm{m}$ compared with the older and more restricted $25-80 \mu \mathrm{m}$ range; this change has assisted in the detection of shards that may have previously been missed (e.g. Timms et al., 2017; 2018; Kearney et al., 2018). Thirdly, improvements to the spatial resolution of characterisation techniques such as Electron Probe Microanalysis (EPMA) has help facilitate the characterisation of smaller glass shards (Hayward, 2012). Fourthly, although it is now common practice to sample sediment sequences contiguously, this has not always been the case, for some studies have deliberately targeted specific stratigraphic intervals in an effort to trace selected tephra layers (e.g. Roberts, 1997; Wastegard et al., 2000; Pyne-O'Donnell et al., 2008; Bramham-Law et al., 2013). In these cases and 
particularly in older studies employing 'less-refined' methods, absence of evidence is not necessarily evidence of absence and hence the succession of cryptotephra layers in some studies could be incomplete. Fifthly, most cryptotephra studies are based on one or a few core sequences taken from the deepest part of a lake basin, where it is assumed that the most complete sequence is to be found. So far as tephra layers are concerned, however, this may not be the case, for comprehensive basin-wide studies have shown that not all cryptotephras are evenly distributed and concentrated in the same part of a basin, possibly due to variations in lake level and/or point of sediment focussing, or other taphonomic complications (e.g. Boygle, 1999; Pyne-O'Donnell, 2011; Bertrand et al., 2014). Hence it cannot be assumed that single-core studies have captured the full tephrostratigraphic sequence that is preserved in a lake basin infill. Finally, studies in the British Isles and NW Europe have historically relied on the analysis of major and minor elements for the fingerprinting of glass shards from cryptotephras. There is now, however, an increasing realisation of the potential of trace and rare earth element analyses, particularly in circumstances when major and minor element ratios prove equivocal (Tomlinson et al., 2015; Lowe, D. et al., 2017). In the British Isles and NW Europe, initial applications are yielding results of varying success (e.g. Lane et al., 2012a; Lind et al., 2016; Cook et al., 2018a), but may return dividends if more widely adopted.

In the following section we review the evidence for the tephrostratigraphy of the British Isles for the period c. 16-8 ka BP, taking into account the difficulties summarised above. Sediment records from the British Isles that span this interval often show a clear demarcation of lithostratigraphic units that date to the Dimlington Stadial (DS), Windermere Interstadial (WI), Loch Lomond Stadial (LLS) and early Holocene (Figure 3), a structure which is similarly expressed in the bio-stratigraphic record (see Walker and Lowe, 2017). This pattern can also be observed in climate records spanning the same interval in Europe and Greenland, however, caution must be exercised in declaring synchronicity between these regions, as it remains to be established whether these changes were genuinely time-parallel or offset temporally (Björck et al., 1998; Walker et al., 1999; Walker and Lowe, 2017). With this in mind, the DS can be roughly equated with the Late Weichselian/Late Wisconsinan or Greenland Stadial 2 (GS-2), the WI corresponds to the Bölling-Alleröd period, or Greenland Interstadial 1 (GI-1), and the LLS equates approximately with the Younger Dryas or GS-1 cold episode (Björck et al., 1998; Walker et al., 1999; Rasmussen et al., 2006). The individual tephra layers detected in each of these stratigraphic intervals are presented in chronological order in Table 1 and discussed in the same order below, together with summaries of their key diagnostic data and any significant uncertainties that impact their potential use as isochrons. Collectively these tephra are distributed across the 54 individual 
sites located in Figure 2. A more detailed schematic which includes additional site information is presented in Supplementary Figure S1, while Supplementary Table S1 provides a comprehensive overview of the sites investigated for glass-shard content, the sampling strategies that were adopted and any caveats concerning their stratigraphic context and use as isochronous markers.

263

\subsection{Tephra records of Dimlington Stadial (DS) age}

In the basal sediments of three basins in the Summer Isles, which lie off the NW coast of Scotland and two sites on Orkney (Figure 1; 2; Supplementary Figure S1), cryptotephra shards have been detected that date to the later part of the DS (Weston, 2012; Valentine, 2015; Timms, 2016; Timms et al., 2018). Although none of the layers has been dated directly, their ages can be bracketed on the following grounds. First, they all lie within clastic sediments that pre-date the deposition of WI organic-rich sediments, and although the age of the base of these deposits is uncertain, they must pre-date c. $14.1 \mathrm{ka} \mathrm{BP}$, the age of the Borrobol Tephra, which is consistently found at the base of the organic sediments that overlies them (see section 3.3.1). A maximum age for the basal tephras in the Summer Isles sites is c. 16 ka BP, the age estimate for the retreat of the last ice sheet from this vicinity, while deglaciation on Orkney may have been slightly earlier, by c. 17.0-16.5 ka BP (Phillips et al., 2008; Ballantyne et al., 2009; Hughes et al., 2016; Ballantyne and Small, 2018).

At Tanera Mòr 2 in the Summer Isles (Figure 1), the tephra that pre-dates the WI has a subalkaline rhyolitic glass signature similar to that of tephras produced by the Katla volcano in Iceland. The Dimna Ash, discovered previously at a single site in Norway, also has this chemical signature and has been dated to $15.1 \pm 0.6$ cal. ka BP (Koren et al., 2008). Given the age constraints for the Tanera Mòr 2 basin outlined above, we tentatively correlated this ash layer (TM2 504) with the Dimna Ash (Figure 4; Table 1). Glass shards with a similar Katla-type chemistry and morphology have also been detected in the basal deposits of two other Summer Isles sequences, at Tanera Mòr 1 (Timms, 2016) and at a site on the neighbouring Priest Island (Valentine, 2015). However, these records are more complex. In the Tanera Mòr 1 sequence, two tephra horizons were identified within the basal DS clays (TM1 553 and TM1 546; Supplementary Figure S1), both yielding bi-modal glass chemical data, one component matching the Dimna Ash, and the second showing a chemical affinity to glass of the sub-alkaline Borrobol-type tephras (Figure 4). In the Priest Island record, glass shards are spread diffusely through the basal DS clay deposits, but two shard peaks were identified. The lowermost (PRI 811) did not yield sufficient glass shards for chemical identification, but it is considered to correlate with the Dimna Ash on the basis of shard morphology and stratigraphic position (Valentine, 2015; Supplementary Figure S1). An upper 
peak, which lies closer to the transition between the DS and the WI (PRI-700), shows shard morphological and chemical affinities with Borrobol-type tephras (Figure 4; Table 1). The presence of a DS age Borrobol-type tephra has also been identified at Quoyloo Meadow on Orkney (QM1 242; Timms, 2016; Supplementary Figure S1). In total, there are three sites in the British Isles that show evidence for a Borrobol-type tephra of DS age and collectively they are named here the 'Tanera Tephra' after the island where this tephra is presently most clearly defined.

Cook et al. (2018a) have recently reported the discovery of glass shards with Borrobol-type chemistry within the Greenland Stadial 2 (GS-2) interval in the Greenland ice-core record, which is broadly equivalent to the DS (Rose, 1985; Walker, 1995; Björck et al. 1998; Figure 3 ), and thus suggestive of a match with records from the Summer Isles, and Quoyloo Meadow. However, analyses from the British records are few in number and glass shards exhibit consistently lower $\mathrm{CaO}$ wt \% values than those identified in the ice cores, with the former (British) tephras being more akin to the glass chemical signatures obtained from Borrobol-type tephras dating to the WI (Figure 4). The current evidence is therefore equivocal, as to whether a tephrostratigraphic correlation can be drawn between records in the British Isles and the Greenland ice-core records during this interval, but the possibility justifies further exploration of this layer.

Finally, a single glass shard dating to the Dimlington Stadial has also been recovered from the site of Crudale Meadow on Orkney (CRUM1 676) although, in this instance, the chemical results bear no consistent resemblance to any known Icelandic volcanic source and has tentatively been matched to a source in Kamchatka (Timms et al., 2018). Hence the status of this record and its potential as an isochron remain uncertain.

\subsection{Tephra records of Windermere Interstadial (WI) age}

\subsubsection{Borrobol-type tephras}

The number, climatostratigraphic position, age, source and glass chemical composition of the Borrobol-type tephras have been a focus of research for more than 20 years (Turney et al., 1997; Davies et al., 2004; Pyne-O’Donnell, 2007; Pyne-O'Donnell et al., 2008; Lind et al., 2016; Cook et al., 2018a). Glasses of Borrobol-type tephras are sub-alkaline rhyolites with high potassium values and characteristically low $\mathrm{FeO}$ (c. 1.5-1.3 wt \%) and $\mathrm{CaO}$ (c. 0.7-0.6 wt \%) totals (Table 1). The exact source of these Borrobol-type tephras has yet to be established, but a growing body of evidence points toward an as yet unknown volcano in Iceland (e.g. Pyne-O'Donnell, 2007; Lind et al., 2016; Cook et al., 2018a; Plunkett and 
Pilcher, 2018). Current evidence suggests that there were two, or possibly three, eruption events during the WI that delivered chemically indistinguishable Borrobol-type tephra to the British Isles. In order of their date of discovery and stratigraphic superposition, these are defined as the Borrobol Tephra, first reported from a site in NE Scotland (Lowe and Turney, 1997), the Penifiler Tephra, first reported from a site on the Isle of Skye (Pyne-O'Donnell, 2007) and the CRUM1 597 Tephra, first reported from, and presently unique to, Crudale Meadow and the adjoining Spretta Meadow site on Orkney (Timms, 2016; Timms et al., 2018; Supplementary Figure S1). Of the three, the Borrobol Tephra is recognised in the largest number of sequences in the British Isles, and in the majority of sites it consistently coincides with the onset of organic deposition that reflects the influence of the warmer temperatures of the WI (Matthews et al., 2011; Cook et al., 2018a). The Penifiler Tephra, on the other hand, appears mostly to coincide with a later short-lived phase of enhanced clastic sediment deposition and reduced summer temperatures, thought to equate with the GI-1d interval (cf. Older Dryas) in the Greenland stratotype sequence (Pyne-O'Donnell, 2007; Matthews et al., 2011; Candy et al., 2016; Figure 3). The CRUM1 597 Tephra, dated to $12,457 \pm 896$ cal. BP (Timms et al., 2018), falls close to the WI-LLS transition, but since it has been detected only on Orkney Mainland, its potential to serve as an isochron has still to be tested, although there is some tentative evidence to suggest that it could be represented in other sequences (Table 2; Supplementary Figure S1).

These three tephras are critically positioned with respect to important climatic transitions and hence offer the potential for precise correlation of records that span the LGIT. However, their overlapping glass chemical signature, can at times, make correlations problematic. This difficulty has been exacerbated by inconsistent stratigraphic interpretations and terminology in the literature reporting the British records, as illustrated by successive changes in perspective concerning the WI tephrostratigraphic record in the Borrobol type-site (Figure 5). Initially, Turney et al. (1997) proposed two stratigraphically distinct but chemically indistinguishable WI tephra layers (Figure 5A), the lower considered a primary deposit and named the Borrobol Tephra, but the upper not named because it was considered to be reworked Borrobol material (Turney, 1998b). A reinvestigation of this sequence by PyneO'Donnell et al. (2008) confirmed the two peaks near the base of the WI reported by Turney et al. (1997), but additionally traced a third tephra layer at a higher level within the WI sediments (Figure 5B), a sequence in accord with new WI tephra records from sites on the Isle of Skye (Pyne-O'Donnell, 2005). These apparent consistent tephrostratigraphic series were considered to indicate that all three chemically-identical layers represented primary ash-fall events and so the two distinct tephra peaks originally reported by Turney et al. 
was considered the correlative of the Penifiler Tephra, a newly-discovered tephra detected in the Druim Loch sequence on Skye (Figure 5B; Pyne-O'Donnell, 2007). A subsequent reinvestigation of the Borrobol type site by Lind et al. (2016) led to a further revised scheme, in which the upper tephra layer reported by Pyne-O'Donnell et al. (2008) was not recognised, only the two basal layers originally reported by Turney et al. (1997). Lind et al. (2016) opted to assign the 'Borrobol A' layer to the Borrobol Tephra, but the 'Borrobol B' layer to the Penifiler Tephra (Figure 5C). It appears, therefore, that the Borrobol Tephra is stratigraphically consistent, but the designation of a 'Penifiler Tephra' has proved more contentious.

The above example illustrates the difficulty of resolving tephra layers with near-identical glass chemical signatures which are in close stratigraphical and/or chronological occurrence: it may not always be possible to resolve individual ash layers, which may represent separate ash-fall events, if the rate of sedimentation is too low. But other factors may also obscure matters, including one already alluded to, namely the possibility of secondary reworking of volcanic ash. The stratigraphic inconsistency of tephra layers assigned to the Penifiler Tephra, which often appear to merge with the underlying Borrobol Tephra (e.g. in the Borrobol, Tynaspirit West and Whitrig Bog records; see Supplementary Figure S1), might favour a reworking hypothesis to account for its origin. The Borrobol Tephra was deposited relatively soon after the end of the DS during a phase of active paraglacial readjustment when it is likely that slopes surrounding many newly formed lake basins were still sparsely vegetated, supporting immature, loosely-bound materials at the land surface (Walker, 1984; Ballantyne and Harris, 1994; Ballantyne, 2002). This setting could have promoted the reworking of such materials containing glass shards, especially in high-altitude sites exposed to flushing by melting snow and ice (Davies et al., 2007). Relevant in this context is that layers assigned to the Penifiler Tephra generally coincide, or closely align, with a climatic oscillation at c. $14.0 \mathrm{ka} \mathrm{BP}$ (broadly equivalent to Gl-1d), a period that witnessed a cooling of mean summer temperatures of c. $2-3^{\circ} \mathrm{C}$ in Scotland (Brooks and Birks, 2000; Brooks et al., 2012, 2016); this could have provoked a resurgence of periglacial conditions and increased

On the other hand, reworking of Borrobol Tephra is a less probable explanation for tephra layers assigned to the Penifiler Tephra in the following contexts: i) where there is a clear stratigraphic separation between the Borrobol and Penifiler layers, as is the case of the Abernethy Forest and Muir Park Reservoir profiles (Supplementary Figure S1); ii) where the peak values in shard concentration for the Penifiler Tephra post-date the GI-1d interval, as in 

the Pulpit Hill, Loch Ashik and Tanera Mòr 1 profiles; iii) where the basin catchment size is restricted and the earliest sediments to accumulate in the basin post-date the Borrobol Tephra, as is the case in the Druim Loch and Tirinie profiles; iv) where the glass shard concentrations of the Penifiler Tephra are greater than those in the underlying Borrobol Tephra as at Quoyloo Meadow and Muir Park Reservoir (Supplementary Figure S1). It would therefore be premature to dismiss the possibility that at least two eruptive events are represented in the sometimes diffuse Borrobol-type tephra record that is to be found in early WI and GI-1d deposits in the British Isles (Davies et al., 2004).

On current evidence, therefore, the Borrobol Tephra appears stratigraphically secure and its 
Stratigraphic and chronological issue with the Penifiler Tephra may be reduced if routine application of magnetic separation procedures were applied to 'Penifiler' Intervals. The rationale for this approach stems from the discovery of glass shards with basaltic chemistry alongside the Penifiler Tephra at the site of Loch Ashik, Isle of Skye (Pyne-O'Donnell et al., 2008; Table 1; Supplementary Figure S1). This basaltic component has a major and minor element signature matching glass of the Katla volcanic system, and is indistinguishable from the basaltic glass component of the Vedde Ash (Figure 6). In the NGRIP ice-core record, a tephra of similar stratigraphic position and chemistry has been identified (Mortensen et al., 2005; Figure 6). This tephra is clearly defined at a depth of $1573 \mathrm{~m}$ within NGRIP where it is dated to 14,020 \pm 84 a b2k (before the year 2000; Abbott and Davies, 2012), overlapping with the accepted age of the Penifiler Tephra identified in the British Isles. The robustness of this link and utility of this layer is difficult to assess as, at present, the basaltic component of the Penifiler has only been recognised at Loch Ashik and attempts to trace this layer to other sites has proved unsuccessful (e.g. Timms et al., 2017). It seems unlikely that the basaltic component of the Penifiler Tephra is as widespread as the rhyolitic fraction, but the opportunity this layer presents to reduce the stratigraphic and chronological uncertainties associated with the Penifiler Tephra suggests that it warrants further systematic testing.

\subsubsection{Mount St Helens J and Glacier Peak G, B}

The site of Finglas River in SW Ireland is a $60 \mathrm{~cm}$ exposure of limnic organic muds which date to the latter part of the WI (named the Woodgrange Interstadial in Ireland; Bryant, 1974). It was one of the early sites to be examined for cryptotephra using the experimental density separation techniques (Turney 1998a,b). Those investigations revealed a tephra layer toward the base of the sequence (c. $53 \mathrm{~cm}$; Supplementary Figure S1), which, when analysed, yielded four shards of a mixed chemical composition (Supplementary Table S2). Two shards (group A) are defined by relatively low $\mathrm{Al}_{2} \mathrm{O}_{3}$ (c. 11.84 wt \%), $\mathrm{FeO}$ (c. 0.95 wt \%), $\mathrm{CaO}$ (c. $1.12 \mathrm{wt} \%$ ) values; one shard (shard $\mathrm{B}$ ) has higher $\mathrm{Al}_{2} \mathrm{O}_{3}$ (12.82 wt \%), $\mathrm{FeO}(1.15 \mathrm{wt}$ $\%$ ), $\mathrm{CaO}(1.34 \mathrm{wt} \%$ ) totals in comparison (Table 1); and a third shard (shard $\mathrm{C}$ ) reveals $\mathrm{Al}_{2} \mathrm{O}_{3}(11.82 \mathrm{wt} \%), \mathrm{FeO}(1.44 \mathrm{wt} \%), \mathrm{CaO}(0.75 \mathrm{wt} \%)$ totals. At the time of study these shards with multiple compositions could not be correlated with any known tephra, being chemically different from the Vedde Ash and the limited number of Borrobol Tephra analyses available at the time (Turney 1998b; Figure 7). However, a re-examination of these results in the present study has revealed similarities with eruptions of WI equivalent age from Glacier Peak and Mount St Helens, two volcanic centres in the North American Cascades range (Figure 1). 
Mount St Helens is known to have erupted several times though the LGIT producing two main tephra units, the older set S (c. 16.0 cal. ka BP) and the younger set J (c. 13.8-12.8 cal. ka BP), with each set consisting of multiple tephra layers from separate eruptions (Clynne et al., 2008; Pyne-O'Donnell et al., 2016). Cumulatively these tephras are referred to as the 'Swift Creek' stage, and at present there are no reliable means by which these tephras can be separated chemically (Pyne-O'Donnell et al., 2016). Interstadial-age volcanic activity at Glacier Peak followed that at Mount St Helens and consisted of a series of closely spaced eruptions leading to the formation of at least three tephra sets (Porter, 1978). The most widely dispersed are sets $\mathrm{G}$ and $\mathrm{B}$, which have a current best age estimate of 13.71-13.41 cal. ka BP (Kuehn et al., 2009). These phases can be distinguished from one another using abundance ratios of $\mathrm{CaO}$ and $\mathrm{FeO}$, and can be further differentiated from the Mount St Helens tephras using $\mathrm{K}_{2} \mathrm{O}$ (Kuehn et al., 2009; Pyne-O'Donnell et al., 2016; Figure 7).

At Finglas River, group A shards compositionally match with those of the Glacier Peak set G, the group B shard with those of Mount St Helens, and the group $C$ shard with those of the Borrobol-type series (Figure 7). The presence of both Glacier Peak and Mount St Helens in the same 'single' layer is not unusual-across North America these tephras are frequently reported as a visible tephra couplet (Kuehn et al., 2009), and in cryptotephra investigations in south-eastern Canada these tephras have also been identified within the same mixed horizon (Pyne-O'Donnell et al., 2016). At Finglas River, as in North America, the coeval expression of these tephra can be explained by a low sedimentation rate at the site of deposition and a conflation of these individual isochrons. Presently this is the only confirmed incidence of a Mount St Helens tephra shard being identified in interstadial deposits outside of North America, and only one of two reported occurrences of Glacier Peak shards identified in an ultra-distal setting. The second finding has recently come from western Scotland, where shards of Glacier Peak B and G sets have also been identified alongside shards of the Borrobol-type tephra series, and specifically those correlated to the Penifiler Tephra (Pyne-O'Donnell and Jensen, 2018; Supplementary Table S1; S2). Whether these shards identified in Ireland and Scotland are of sufficient concentration to declare the presence of an isochron is perhaps a contentious matter. Nevertheless the presence of these ultra-distal glass shards at two sites does suggest that given thorough investigation it may be possible to define and constrain these 'tephra' more precisely in the British Isles.

511 The interstadial eruptions from Mount St Helens and Glacier Peak are well documented in 512 North America and have become important regional marker horizons for the dating and 513 correlation of palaeoenvironmental and archaeological records (see Kuehn et al., 2009; 514 Pyne-O'Donnell et al., 2016). Their detection in the British Isles over $7000 \mathrm{~km}$ from source 
raises the exciting potential for inter-continental correlation and synchronisation of records dating to the LGIT. Focus must now be on refining their presence within the known records in Ireland and Scotland, as well as searching for these ultra-distal tephras, and others, in records across the British Isles and NW Europe, especially in sequences that can be examined at a high temporal resolution. This aim, however, may prove difficult given the prominence of other ash layers dating to around the same time and possible 'masking' by recycled tephra shards (e.g. Davies et al., 2007; Timms et al., 2017). Trace amounts of the Mount St Helens and Glacier Peak tephras are likely to be obscured by the similarly-aged Penifiler Tephra in some sites (Pyne-O'Donnell and Jensen, 2018). Such difficulties might, however, be overcome by a more thorough 'forensic' approach in the examination of shard distributions, morphological properties and chemical compositions, with a higher sampling resolution than has been the norm hitherto (e.g. Pyne-O'Donnell, 2011; Timms et al., 2017; McLean et al., 2018; Pyne-O'Donnell and Jensen, 2018).

\subsubsection{Roddans Port Tephra}

Two tephra layers have been reported from sediments of WI age preserved at the site of Roddans Port, an intertidal sequence that is intermittently exposed off the coast of County Down, Northern Ireland (Turney et al., 2006). Labelled Roddans Port A and B, the precise age of these tephra layers is uncertain, but they lie within the middle part of deposits assigned to the WI. While their glass-derived chemical signatures have been suggested as Icelandic in origin (Turney et al., 2006), they do not resemble those of either the Borroboltype or silicic Katla tephras known to have been deposited through this interval (Figure 8; Table 1; see section 3.4), and Turney et al. (2006) were uncertain as to whether they represent two closely-timed primary ash-fall events or a primary and reworked event. A chemically similar distal volcanic ash has been reported from the site of Vallensgård Mose on Bornholm Island, Denmark (Turney et al., 2006), but it lies within sediments assigned to the Younger Dryas interval. Some similarity can be observed between the Roddans Port B 
composition (Supplementary Table S2); two shards (group A) are defined by relatively high $553 \mathrm{FeO}(2.17-2.53 \mathrm{wt} \%)$ and $\mathrm{TiO}_{2}$ (0.63-0.89 wt \%) totals; two shards (group B) exhibit low $554 \mathrm{FeO}$ values (1.05-1.17 wt \%) and similar $\mathrm{TiO}_{2}$ totals (0.67-0.69 wt \% ); a single shard (shard $555 \mathrm{C})$ is characterised by $\mathrm{FeO}$ values of $(1.37 \mathrm{wt} \%)$ and lower $\mathrm{TiO}_{2}(0.14 \mathrm{wt} \%)$ totals; and one 556 further shard (shard D) expresses comparatively low $\mathrm{FeO}(0.47 \mathrm{wt} \%)$ totals and 557 comparatively high $\mathrm{TiO}_{2}(0.71 \mathrm{wt} \%)$ values. This mixed chemical assemblage and the stratigraphic occurrence of the layer within sediments relating to an unstable landscape and transitioning climate, might suggest a reworked origin, a hypothesis further supported by low analytical totals of c. $93 \mathrm{wt} \%$, which may indicate some degree of post-depositional alteration. Whilst caution must therefore be expressed in interpreting these analyses, the chemical signature of at least two of the groups bears some resemblance to known tephras of WI age. Group B shows some chemical similarity to eruptives of Mount St Helens, particularly in plots of $\mathrm{FeO}, \mathrm{CaO}$ and $\mathrm{K}_{2} \mathrm{O}$ (Figure 8). However, this overlap is not consistent across all major and minor elements, with $\mathrm{TiO}_{2}$ in particular exhibiting significantly higher values than those expected from the Cascades range (Figure 8 ). Shard $C$ shows an affinity with the Borrobol-type tephras, whereas group $A$ and shard D do not appear to overlap with any rhyolitic tephra analyses known to occupy this interval (Figure 8). During a reinvestigation of the Loch an t'Suidhe site by Pyne-O'Donnell (2005), multiple cores were investigated and several of these revealed comparable peaks in shard concentration at similar stratigraphic intervals to those of the LAS-1 tephra layer. However, no glass compositional analyses were undertaken. At present therefore the significance of the LAS-1 analyses and the relationship these may have to known tephras of Interstadial-Stadial age cannot be resolved. However, the possible occurrence of the ultra-distal Mount St Helens $\mathrm{J}$ Tephra should be enough to warrant a re-investigation of the tephrostratigraphic record.

\subsection{Tephra records of Loch Lomond Stadial (LLS) age}

\subsubsection{The Vedde Ash}

580 The Vedde Ash is one of the best documented, securely-dated and widely-distributed 581 volcanic ash layers dating to the LGIT. The source of the ash is generally believed to be 582 from the Katla volcanic system on Iceland (Mangerud et al., 1984; Lacasse et al., 1995; 583 Lane et al., 2012a; Tomlinson et al., 2012; Figure 1) and was first detected as a component 584 of the North Atlantic Ash Zone 1 (e.g. Ruddiman and Mclntyre, 1981), and later as a 585 distinctive individual marker horizon by Mangerud et al. (1984) in several lake sequences 586 (including at the locality of Vedde) in the Ålesund area of western Norway. Since then, the 587 Vedde Ash has been detected in sites ranging from as far north as the Greenland ice sheet 588 to Italy and Slovenia in the south (Grönvold et al., 1995; Mortensen et al., 2005; Lane et al., 
2011a; Bronk Ramsey et al., 2015). Typically it is the rhyolitic glass fraction which is most far 590 travelled, however, the Vedde Ash also comprises less well-distributed basaltic glass (Table 591 1), and an intermediate dacitic glass component currently restricted to a number of sites in 592 western Norway (see Lane et al., 2012a).

The Vedde Ash has consistently been found in sediments of Younger Dryas age across Europe, and was first identified in the British Isles as a cryptotephra by Lowe and Turney (1997) in their experimental use of the now widely applied density separation procedure (Turney, 1998a; Blockley et al., 2005). At present, glass shards of the Vedde Ash have been detected and chemically analysed in a total of 23 sites in the British Isles, while a further six occurrences have been proposed on stratigraphic grounds (Supplementary Figure S1;

600 Supplementary Table S1), making it the most frequently recognised tephra layer in British 601 LGIT records. It is generally only the rhyolitic end member of the Vedde Ash that is reported from sites in the British Isles, which may in part reflect an inherent bias in density separation protocols toward the lighter (felsic) fraction (Turney, 1998a). The basaltic component is noticeable, however, in two sequences where the Vedde Ash forms a visible layer (Figure 2), on the Isle of Skye (Davies et al., 2001) and on Orkney Mainland (Timms, 2016), and can be detected in cryptotephra layers by the application of magnetic separation techniques 607 (Mackie et al., 2002; Timms et al., 2017, 2018).

The Vedde Ash has been detected in the Greenland ice cores, with an age estimated as $12,171 \pm 114$ a b2k; Rasmussen et al., 2006), while radiocarbon dates are available from a number of terrestrial sites (e.g. Lohne et al., 2014). The most widely employed estimate, however, is $12,023 \pm 43$ cal. BP, derived using a composite Bayesian age model that combines the radiocarbon evidence for the age of the Vedde Ash obtained from several records (Bronk Ramsey et al., 2015). Thanks to its precise age and extensive distribution, the Vedde Ash is a key isochron within the British and European tephrostratigraphic 616 frameworks, enabling the detection of regional time-transgressive environmental changes 617 during the Younger Dryas/LLS interval (e.g. Bakke et al., 2009; Lane et al., 2013;

618 Muschitiello and Wohlfarth, 2015; Brooks et al., 2016).

\subsubsection{The Abernethy Tephra}

621 A tephra layer that lies close to, or coincides with, the LLS/Holocene boundary has recently been proposed, based on evidence from a number of Scottish, Swedish and Norwegian records; it has been named the Abernethy Tephra, after the site in NE Scotland where it is 624 best represented (Matthews et al., 2011; MacLeod et al., 2015). Its dominant glass chemical 625 signature suggests it originated from the Katla volcanic system, with a composition similar to 
626 that of the Vedde Ash and several other tephra layers dating to the LGIT (Table 1), including the Dimna Ash (Koren et al., 2008), the R1 (Thornalley et al., 2011), the IA2 (Bond et al., 2001), and the Suduroy tephras (Wastegård, 2002). With the exception of the Vedde Ash, however, confusion of the Abernethy Tephra with these others can be resolved on stratigraphic grounds. The LLS is clearly marked in LGIT sequences in the British Isles by a prominent minerogenic lithological unit (Figure 3); the Suduroy post-dates this unit and the Dimna, R1 and IA2 tephras all pre-date it. The uncertain issue that remains is whether the Abernethy Tephra represents a primary ash-fall event, or reworked material derived from older tephras with similar chemical composition.

The strongest evidence for primary airfall comes from the detection of the Abernethy Tephra in glaciolacustrine varve records from Lochaber, Scotland (MacLeod et al., 2015). In this composite record two tephra horizons were detected, the lower exhibiting morphological properties typical of the Vedde Ash: i.e. platy featureless shards (see Mangerud et al., 1984; Lane et al., 2012a), whilst the upper revealed a silicic Katla signature and was assigned to the Abernethy Tephra (MacLeod et al., 2015). Importantly, these tephra layers are separated by a minimum of c. 300 years with no evidence of shard remobilisation in the intervening sediments. This paucity is despite sedimentological evidence indicating that the local catchment was susceptible to erosion and remobilisation (Palmer et al., 2010). At several other sites in Scotland, a lower peak in shard concentration (the Vedde Ash) and an upper peak (the Abernethy Tephra), are separated by an interval where no shards have been detected (see MacLeod et al., 2015). In these cases, the possibility of reworking of older Katla tephra layers (i.e. the Vedde Ash) into a discrete layer at the Holocene transition also seems unlikely. At Kingshouse 2 on the Rannoch Plateau, sedimentation of the basin began only toward the latter phases of the LLS. This timing precludes reworking as a hypothesis to explain the presence of the Abernethy Tephra because the basin was not in existence during the eruption of the Vedde Ash (Lowe et al., in prep). In these examples it is more likely that the silicic Katla-type tephra identified, and assigned to the Abernethy Tephra, is derived from a separate eruption event dating to the latter stages of the LLS (cf. Younger Dryas). It is worth noting that evidence from Iceland indicates that the Katla volcano erupted several times during the Younger Dryas (Van Vliet-Lanoë et al., 2007). Hence it is reasonable to suggest multiple Katla-derived ash clouds may have crossed the British Isles and NW Europe during this period. 
tephra are found together (Supplementary Figure S1). In many cases there is also a

664 background of shards spanning the interval between the Vedde and Abernethy tephras, which suggests recycling of Vedde Ash shards may be responsible for the secondary 'Abernethy' peak in these circumstances. Furthermore, the glass chemical signature of the Abernethy Tephra obtained from records in the British Isles, is in many instances, mixed (Table 3; Figure 9). Whilst this heterogeneous chemical signal may represent a coeval eruption of two or more volcanic centres, it may also be further evidence of shard remobilisation. The harsh climatic conditions that prevailed during the LLS are known to have resulted in the reworking of soils, pollen and other biological remains into lake basins (Lowe and Walker, 1986; Lowe and Lowe, 1989), and there is no reason why tephra would be exempt from these processes.

In view of the evidence presented by MacLeod et al. (2015) from sites where two welldefined and stratigraphically discrete peaks in shard concentrations have been identified, the possibility that the Abernethy Tephra reflects a primary fall event should be retained. However, it is important to be mindful of the impact of enhanced sediment remobilisation processes operating during periods of abrupt climatic change, and the interpretation of tephrostratigraphic records that span these intervals. There is also a need to refine the age of the Abernethy Tephra because the present estimate of 11,462 $\pm 122 \mathrm{cal}$. BP has a large error range and is based on interpolation of an age model in which investigation of the Abernethy Tephra was not the focus of the dating programme (Matthews et al., 2011; Bronk Ramsey et al., 2015).

685

\subsection{Tephra records of early Holocene age}

687

\subsubsection{CRUM1 561 (Crudale Tephra)}

689 In recent tephrostratigraphical investigations at Crudale Meadow, Timms et al. (2018) 690 identified tentative evidence for an eruption of Tindfjallajökull, a volcano that lies within the 691 Icelandic Eastern Volcanic Zone (Figure 1). Only a few analyses were obtained (Table 1), 692 and these were from shards spread over a $26 \mathrm{~cm}$ interval spanning the LLS-early Holocene, 693 and which were mixed with shards of a silicic Katla signature. Shards are defined by FeO 694 values of (c. $2.55 \mathrm{wt} \%$ ), and relatively low $\mathrm{CaO}$ (c. $0.38 \mathrm{wt} \%$ ) and high $\mathrm{K}_{2} \mathrm{O}$ (c. $4.09 \mathrm{wt} \%$ ) 695 totals. Timms et al. (2018) commented upon the similarity of the CRUM1 561 analyses with 696 those of the Torfajökull volcano, but the overall glass chemical signature presented a 697 stronger correlation to the Tindfjallajökull centre. This correlation was based principally on 698 published glass and pumice data of the Thórsmörk Ignimbrite eruption believed to have 699 originated from Tindfjallajökull c. 57,300 cal. BP (Jørgensen, 1980; Tomlinson et al., 2010). 

However, new field survey and petrological data from Moles et al. (2018) and Moles et al. (in review) would suggest that this correlation requires revision and that the Thórsmörk Ignimbrite eruption instead originated from the Torfajökull complex.

In a re-examination of existing chemical data for this study, shards of a similar chemical composition to those of the CRUM1 561 analyses were identified amongst data correlated to the Vedde Ash at Tynaspirit West (Figure 10; Roberts, 1997). Accepting the proposal of Moles et al. (2018, in review), the tephra evidence from Crudale Meadow and Tynaspirit West would suggest that an eruption of Torfajökull occurred during the PleistoceneHolocene transition and that it was large enough, or atmospheric conditions were suitably favourable, to disperse tephra over the British Isles. Presently, because of poor stratigraphical control, a precise age estimate for the Torfajökull-type tephra identified at Crudale Meadow and Tynaspirit West cannot be given, only that one or more eruptions occurred between c. 12,111 and 11,174 cal. BP (Timms et al., 2018). As tephra of this chemical composition can now be tentatively identified at two sites, we propose 'Crudale Tephra' as a formal name to refer to shards exhibiting this chemical signature, and which are positioned within the Pleistocene-Holocene transition.

Interestingly glass analyses of the Crudale Tephra bear a stronger chemical resemblance to the older Torfajökull rhyolites than those which erupted later in the Holocene (Figure 10). McGarvie et al. (1990) noted there are several temporal trends in the postglacial rhyolites originating from the Torfajökull complex (whole rock analyses), most notably a depletion in $\mathrm{SiO}_{2}$ and an enrichment in $\mathrm{TiO}_{2}, \mathrm{Al}_{2} \mathrm{O}_{3}, \mathrm{MgO}$ and $\mathrm{CaO}$ wt \%. Accepting the limitations of comparing glass and whole-rock data, these trends potentially could explain some of the chemical differences observed in Figure 10 between the older Crudale Tephra and the younger Ashik, An Druim-Høvdarhagi and LAN1-325 tephras which are also thought to originate from the Torfajökull complex (Pyne-O'Donnell, 2007; Ranner et al., 2005; Lind and Wastegård, 2011; Matthews, 2008). Further work is needed to establish whether the Crudale Tephra extends to other sites in the British Isles and whether glass analyses for this tephra may offer a more chemically distinctive marker for the LLS-Holocene transition than those for the Abernethy Tephra.

\subsubsection{The Hässeldalen Tephra}

The Hässeldalen Tephra has become one of the most important early-Holocene tephra horizons for palaeoclimate records in NW Europe. First identified in southern Sweden (Davies et al., 2003), this rhyolitic tephra has been repeatedly found in close association with proxy responses to the onset of the Pre-Boreal Oscillation (PBO; Wohlfarth et al., 2006; Ott 
et al., 2016). Several Icelandic sources have been proposed for the Hässeldalen Tephra including Snæfellsjökull in western Iceland (Davies et al., 2003; Figure 1). However, recent work by Wastegård et al. (2018) shows that glass shards of tephras originating from this centre have distinctively high $\mathrm{Al}_{2} \mathrm{O}_{3}$ values (c. 15-16 wt \%), which the Hässeldalen Tephra does not exhibit (Table 1). An alternative source proposed by Wastegård et al. (2018) is the Thórdarhyrna volcano located under the Vatnajökull ice-cap (Figure 1); however, at present this correlation is based on whole-rock analyses, and an investigation of the vitreous phase of Thórdarhyrna will be necessary to further test this hypothesis.

Extensive radiocarbon dating at the type-site, Hässeldala port, has generated an age estimate of $11,387 \pm 270$ cal. BP (Ott et al., 2016), although remodelling of the Høvdarhagi bog sequence in the Faroe Islands by Wastegård et al. (2018) has recently refined this estimate to $11,316 \pm 124 \mathrm{cal}$. BP. The Hässeldalen Tephra has a frequent occurrence in Scandinavia and northern Europe (e.g. Davies et al., 2003; Lind and Wastegård, 2011; Lane et al., 2012b; Housley et al., 2013; Lilja et al., 2013; Larsen and Noe-Nygaard, 2014; Wulf et al., 2016), but at present a fairly limited distribution in the British Isles. Only tentative evidence is available from Rubha Port an t-Seilic on Islay (Mithen et al., 2015) and from Quoyloo Meadow on Orkney Mainland (Timms et al., 2017), with both records subject to stratigraphic uncertainties. A more robust record, however, has been obtained from Crudale Meadow on Orkney Mainland (Timms et al., 2018) and more recently from the central Scottish Highlands (Lowe et al., in prep). On present evidence it appears that the Hässeldalen ash plume had a narrow dispersal range over the northernmost part of the British Isles (Wastegård et al., 2018). However, this distribution pattern could be misleading, as its presence could be masked by remobilisation of more abundant Vedde Ash glass shards, a problem that complicates the refinement of many early Holocene tephrostratigraphies (e.g. Mangerud et al., 1984; MacLeod et al., 2015; Timms et al., 2017; 2018).

\subsubsection{The Askja-S and CRUM1 510 tephras}

766 The Askja-S Tephra was first identified in a distal setting at Hässeldala port, south-eastern 767 Sweden (Davies et al., 2003), and is thought to derive from the Askja-Dyngjufjöll system, a 768 caldera in the central Highlands of Iceland (Sigvaldason, 2002; Figure 1). Also referred to as 769 the Askja-10ka Tephra, it is one of the few LGIT distal tephra layers with a known proximal 770 correlative (Sigvaldason, 2002; Jones et al., 2017) it is one of the most widely dispersed 771 tephras originating from Iceland during the LGIT, being found as far south as the Alps, 772 Slovenia and east into Romania (Lane et al., 2011b; Kearney et al 2018). Characterised by 773 distinctive $\mathrm{FeO}$ (c. $2.52 \mathrm{wt} \%$ ) values and relatively low $\mathrm{K}_{2} \mathrm{O}(2.49 \mathrm{wt} \%$ ) totals (Table 1), the 
774 Askja-S was first identified in the British Isles as a series of deposits in Northern Ireland

775 (Turney et al., 2006), but has more recently been traced to sites in central Scotland (Kelly et 776 al., 2017; Lowe et al., 2017; Lowe et al., in prep), Wales (Jones et al., 2017) and Orkney 777 Mainland (Timms et al., 2017, 2018; Figure 2). The widespread distribution of the Askja-S, 778 its glass compositional distinctiveness for the time period and its presence in a series of 779 high-resolution sedimentary records, has enabled a well-constrained age estimate of 10,824 $780 \pm 97$ cal. BP to be derived by composite or 'multi-site' Bayesian age-modelling (Kearney et al., 2018; Bronk Ramsey et al., 2015). This age estimate has recently been challenged by Ott et al. (2016), who suggested an estimate of 11,228 \pm 226 cal. BP, based on the Askja-S' occurrence within an annually resolved record in Lake Czechowskie, Poland. However, there is some uncertainty as to how the age of the Askja-S Tephra was derived in this study, the varve record is floating, but has been anchored in time by importing the age estimate for the Hässeldalen Tephra, which is also present in the record. This is slightly problematic, as it is unclear whether it is the age of the Hässeldalen, the age of the Askja-S, or both tephra age estimates which may need revision. Thus although the results from Lake Czechowskie offer an excellent opportunity to refine the age of early Holocene tephras, it is evident that further work is necessary to anchor the Czechowskie varve chronology at a point independent from the two tephra isochrons that are under scrutiny. Hence until this point is cleared up, we adopt the age estimate generated by Kearney et al. (2018).

At Crudale Meadow, Orkney Mainland, the Askja-S Tephra is identified alongside a basaltic ash layer, provisionally named the CRUM1 510 Tephra, sourced from the Grímsvötn volcano, which lies beneath the Vatnajökull ice cap (Timms et al., 2018; Figure 1). With an estimated age of $10,837 \pm 148 \mathrm{cal}$. BP, this is the oldest Grímsvötn eruptive to have been detected in the British Isles during the Holocene, and this is the first record where the Askja$S$ Tephra is found in association with a basaltic glass component. Like the earlier Hässeldalen Tephra, the Askja-S and CRUM1 510 tephras are closely associated with the $\mathrm{PBO}$, with the latter two tephras appearing to coincide with the termination of this event (Davies et al., 2003; Wohlfarth et al., 2006). This combination of the Hässeldalen, Askja-S and CRUM1-510 tephras all found in such close association will constitute a powerful tool for testing the spatial and temporal variability of the environmental response to the PBO across the British Isles and mainland Europe.

\subsubsection{The Ashik Tephra}

The Ashik Tephra, first identified at Loch Ashik on the Isle of Skye, has a bi-modal glass chemistry with a rhyolitic component derived from Torfajökull in south-central Iceland (Figure 
811 1). The tephra has a limited spatial distribution, with the rhyolitic component being identified 812 only in sequences from the Inner Hebrides and Orkney (Pyne-O'Donnell 2007; Timms et al., 813 2017; Figure 2). A possible rhyolitic correlative has also been described from Loch Laggan in 814 the central Grampian Highlands, but it is unclear whether this ash layer relates to the Ashik Tephra or to one of the younger Torfajökull-derived tephras (MacLeod, 2008; Supplementary Figure S1). The basaltic component has thus far been chemically analysed only at the site of Druim Loch, on the Isle of Skye, and correlated with the Loch Ashik tephra series on the basis of tephrostratigraphic superposition (Pyne-O'Donnell, 2005). The age of the Ashik Tephra was not well known, described as being "below the Saksunarvatn Ash" (Pyne-

\section{O'Donnell, 2007), until refined by a tephra-based Bayesian age model for the site of Quoyloo} Meadow on Orkney, to $10,716 \pm 230$ cal. BP (Timms et al., 2017).

A key question concerning the Ashik Tephra is its tephrostratigraphic relationship with the Askja-S Tephra. These ash layers have a limited distribution in the British Isles, but occupy a very similar stratigraphic position within the early Holocene. This close association has recently been highlighted by the high-resolution work of Timms et al. (2017), who identified both tephra layers in consecutive $1 \mathrm{~cm}$ samples at Quoyloo Meadow (QM1 187, QM1 188 respectively). In this case, it was only the contiguous chemical analyses of adjacent samples which facilitated a separation of these ash layers. As a result it is now known that the rhyolitic component of the Ashik Tephra lies stratigraphically above the Askja-S Tephra. What is not presently clear, however, is the relationship of these ash layers with the basaltic component of the Ashik Tephra and the CRUM1 510 Tephra. With the closely spaced nature of these tephras, it could be that the CRUM1 510 Tephra identified at Crudale Meadow is the same as the 'basaltic Ashik Tephra' described elsewhere (i.e. at Loch Ashik, Druim Loch and Loch an t'Suidhe). Further investigations at finer sampling resolutions or in stratigraphically expanded sequences are required to establish the precise relationship between the rhyolitic Ashik Tephra, the rhyolitic Askja-S Tephra and the accompanying Grímsvötn basalt (i.e. the CRUM1 510 and/or the basaltic Ashik Tephra). Despite these uncertainties, the close association between the Ashik and Askja-S tephras makes the former ash layer another potential marker for constraining the end of the PBO phase of climate instability (PyneO’Donnell 2007).

\subsubsection{The Hovsdalur Tephra}

The Hovsdalur Tephra, like the Hässeldalen Tephra, is thought to originate from the Thórdarhyrna volcano in Iceland (Wastegård et al., 2018; Table 1; Figure 1). Only two sites in NW Europe are reported to host the Hovsdalur, the type-site of the same name located in the Faroe Islands (Wastegård, 2002) and Quoyloo Meadow located on Orkney Mainland 
848 (Timms et al., 2017). At the type-site, the Hovsdalur Tephra was discovered at the base of the sequence and was dated by a simple linear extrapolation from a single radiocarbon date obtained from a higher level in the sequence, an approach which may have underestimated the age of the ash layer (Wastegård et al., 2018). This potentially erroneous age has been used to argue that the Hovsdalur at the type-site is misidentified Hässeldalen Tephra (Wastegård et al., 2018), a plausible proposition because they have overlapping glass compositions and both lie within early Holocene deposits (Lind and Wastegård, 2011). At Quoyloo Meadow, however, the layers assigned to the Hovsdalur and Hässeldalen tephras are separated by $5 \mathrm{~cm}$ of sediment and by the Askja-S Tephra; crucially, no shards with a Hovsdalur/Hässeldalen signature were detected in the Askja-S layer (eight shards analysed), making reworking from the Hässeldalen layer unlikely in this instance (Timms et al., 2017). While evidence for the Hovsdalur Tephra is currently limited, the Quoyloo Meadow record does suggest the possibility of a younger (post-Askja-S) eruption event with a Hässeldalen-type signature, but corroborating evidence is needed to confirm this.

\subsubsection{The Saksunarvatn Ash (Saksunarvatn 10-ka series)}

Originating from the Grímsvötn volcanic system, the basaltic Saksunarvatn Ash has long stood as an important marker horizon for the early Holocene in NW Europe (Jöhansen, 1977; Mangerud et al., 1986; Birks et al., 1996; Björck et al., 2001). The widespread distribution of this tephra has allowed it to be traced to a number of high-resolution records where it has been dated precisely to $10,210 \pm 70$ cal. BP at Kråkenes in western Norway (Lohne et al., 2014), and to 10,347 \pm 89 GICC05 a b2k in the Greenland ice-core records (Rasmussen et al., 2006).

In the British Isles, the Saksunarvatn Ash was first identified at Dallican Water in Shetland (Bennett et al., 1992), but has since been traced to a number of other records including Loch of Benston on Shetland (Bondevik et al., 2005), Quoyloo Meadow (Bunting, 1994; Timms et al., 2017), Crudale Meadow (Bunting, 1994; Timms et al., 2018) and was initially thought to be present at Loch Ashik (Pyne-O’Donnell 2007; c.f. Kelly et al., 2017). Tentative correlations based on superposition have also been proposed for the Borrobol sequence (Turney, 1998b) and Loch an t'Suidhe, located on the Isle of Mull (Pyne-O'Donnell, 2005), although no chemical evidence is available to support these correlations (Figure 2; Supplementary Figure S1; Supplementary Table S1).

\section{Recent evidence has cast doubt over the use of the Saksunarvatn Ash as a single} isochronous marker, because several separate Grímsvötn ash layers appear to have been deposited around the time interval c. $10.4-9.9$ ka BP that was originally assigned to the 
'Saksunarvatn Ash' (Jennings et al., 2002, 2014; Jóhannsdóttir et al., 2005; Kristjánsdóttir et al., 2007; Kylander et al., 2011; Thordarson, 2014; Neave et al., 2015; Harning et al., 2018; Wastegård et al., 2018). In total it is believed that as many as seven Grímsvötn tephra layers may have been produced during this 500-year interval, hence leading to the term the 'Saksunarvatn 10-ka series', although it is not clear how many of these were dispersed towards mainland Europe (Jóhannsdóttir et al., 2005; Jennings et al., 2014; Neave et al., 2015; Wastegård et al., 2018). At Havnardalsmyren in the Faroe Islands, five Grímsvötn tephra layers have been reported within early Holocene sediments, and two of these, Havn-3 and Havn-4, can be distinguished on the basis of lower glass-derived $\mathrm{MgO}$ values than found in other 'Saksunarvatn Ash' glass analyses (Wastegård et al., 2018). This distinction has significance for the British tephrostratigraphic framework because the basaltic layer in the Loch Ashik sequence assigned by Pyne-O'Donnell et al. (2007) to the 'Saksunarvatn Ash' also has this characteristically low MgO signal (Wastegård et al., 2018), being further reflected in additional glass analyses provided for this layer in Kelly et al. (2017; Figure 11). It is more likely therefore that the 'Saksunarvatn Ash' at Loch Ashik is a correlative of the Havn-3 or Havn-4 eruptions, which date to between c. 10.37 and 10.3 ka BP, and thus we have revised the tephra record for the Loch Ashik sequence accordingly (Figure 2; Supplementary Figure S1; Supplementary Table S1).

Following this revision, we have reassessed the glass compositional evidence obtained from 'Saksunarvatn Ash' layers in the British Isles (Figure 11). The analyses of the Saksunarvatn Ash at Crudale Meadow by Bunting (1994) clearly exhibit two glass populations, one correlating with the Grímsvötn series and the other plotting close to the compositional envelope of Veiðivötn- Bárðarbunga. Importantly, Veiðivötn- Bárðarbunga glass analyses are also reported from the Havn-0 horizon at Havnardalsmyren (Wastegård et al., 2018), and from Bæjarvötn, a lake-site of similar age in the NW of Iceland (Harning et al., 2018).

911 Wastegård et al. (2018) consider the Havn-0 horizon to represent reworking due to their 912 coeval presence with Grímsvötn analyses. However, at Bæjarvötn the Veiðivötn-

913 Bárðarbunga analyses form a distinct $1 \mathrm{~cm}$ marker horizon layered between Grímsvötn 914 tephra layers of the 10-ka Saksunarvatn series (Harning et al., 2018). This finding hints at 915 the possible discovery of a new isochronous marker in the North Atlantic region and one 916 independent of the issues associated with the Saksunarvatn series. However, reinvestigation 917 of the Crudale Meadow sequence by Timms et al. (2018) failed to detect any glass shards 918 with a Veiðivötn-Bárðarbunga signature despite 29 analyses being obtained. Presently it is 919 not exactly clear why this may be, but a speculative reason might be a slight difference in 920 core location at the Crudale Meadow basin between the studies conducted by Bunting 
921 (1994) and Timms et al. (2018). On current evidence therefore, the significance of the

922 Veiðivötn-Bárðarbunga analyses from Crudale Meadow is not yet substantiated.

All other 'Saksunarvatn' Ash analyses obtained from records in the British Isles plot within the main Grímsvötn envelope, suggesting these probably correlate to either the Havn-2 or Havn-1 tephras described from the Faroe Islands (Wastegård et al., 2018). The recent findings of Harning et al. (2018) and Wastegård et al. (2018) with regard to the 10-ka Saksunarvatn series go some way to resolving, or at the very least circumnavigating, the complex issue of repeated Grímsvötn activity and the associated tephras recorded in early Holocene sedimentary deposits in the North Atlantic region.

\subsubsection{The Fosen Tephra}

The Fosen Tephra has a chemical composition similar to that of the Borrobol-type tephras of the Late Pleistocene (Table 1) and has been described from sites in western Norway (Lind et al., 2013), Denmark (Larsen, 2013), eastern Iceland (Gudmundsdóttir et al., 2016) and Orkney, where it has been dated indirectly using a tephra-based Bayesian age model to $10,139 \pm 116$ cal. BP (Timms et al., 2017). A tentative correlative of this eruptive has also been proposed from a sediment sequence in Loch Laggan in the central Grampian Highlands (MacLeod, 2008; Supplementary Table S1). In the early Holocene, analyses of glass from four other ash layers bear some chemical resemblance to that of the Fosen: the Högstorpsmossen Tephra in Sweden, dated to c. 10,200 cal. BP (Björck and Wastegård, 1999); a component of the L-274 Tephra on the Faroe Islands, dated to c. 10,200 cal. BP (Lind and Wastegård, 2011); population 3 of the QUB-608 Tephra on the Lofoten Islands, dated to c. 9500 cal. BP (Pilcher et al., 2005); and the SSn Tephra c. 7300 cal. BP (Boygle, 1999). All of these ash layers can be described as 'Borrobol-type' in terms of their composition, and there is a strong possibility that at least the first three could represent the same eruptive event (Lind et al., 2013; 2016). At present, poor age control for these records prevents more definitive conclusions, though it seems quite possible that the 'Fosen Tephra' could have a much wider dispersal range than is currently acknowledged.

In Norway and Orkney, the Fosen Tephra has been recognised as occurring just above the Saksunarvatn Ash (Lind et al., 2013; Timms et al., 2017). Therefore the Fosen may form a more useful stratigraphic marker in delineating the 10.3 ka event (Björck et al., 2001), especially given the uncertainties of the Saksunarvatn 10-ka series discussed above (section 3.5.6). The stratigraphic position of the Fosen Tephra may also make it a useful isochron for marking the onset of the 'Erdalen Events' (c. 10.10-10.05 ka BP and 9.7 ka BP), a series of glacier advances in Norway thought to have been triggered by a phase of climatic 
instability (Dahl et al., 2002). These Erdalen Events are relatively understudied in NW

959 Europe, but their effects may have been felt elsewhere around the periphery of Scandinavia, 960 including in the British Isles. Tracing of the Fosen Tephra beyond its current known limits may therefore help focus research into understanding their wider geographical impacts.

\subsubsection{The An Druim-Høvdarhagi Tephra}

The An Druim Tephra is the third of four early Holocene rhyolitic ash layers thought to originate from the Torfajökull volcanic centre (Figure 10) and, like its predecessors, the Crudale Tephra and the Ashik Tephra, has a limited distribution (Figure 2; Table 1). The tephra was originally described from Lochan An Druim on the north coast of Scotland (Ranner et al., 2005), but recent work by Kelly et al. (2017) and Timms et al. (2017) have confirmed the occurrence of this tephra in sites in the Grampian Highlands and in Orkney. These studies also present a strong case for linking the An Druim Tephra with the Høvdarhagi Tephra identified in the Faroe Islands and for both being representative of the same eruption. Lind and Wastegård (2011) on the other hand have argued for a separation of these tephras based on marginally higher $\mathrm{CaO}$ and $\mathrm{MgO}$ wt \% values in analyses of glass of the Høvdarhagi Tephra (Figure 10). This small chemical variance could result from the delivery of shards with a narrower chemical range to Scottish sequences and/or as an artefact of smaller sample sizes used in the Scottish studies (Kelly et al., 2017; Timms et al., 2017; Wastegård et al., 2018), or through analytical imprecision (e.g. Lowe, D. et al. 2017). A re-run of the Lochan An Druim and Høvdarhagi age-depth models using the updated OxCal parameters of Bronk Ramsey (2008; 2009), Bronk Ramsey and Lee (2013), and utilising the IntCal13 calibration curve (Reimer et al., 2013), indicates that these tephras overlap chronologically (Timms, 2016), adding weight to the argument that they share the same source. We propose on current evidence that the best-estimate age for the An DruimHøvdarhagi Tephra is $9648 \pm 158$ cal. BP, based on the remodelled An Druim chronology, and therefore provisionally offers an additional marker horizon for establishing the wider impacts of the early Holocene Erdalen Events (Timms, 2016).

\subsubsection{The LAN1-325 Tephra}

Within the current British tephrostratigraphic framework, the LAN1-325 Tephra is the fourth and youngest ash layer thought to originate from the Torfajökull volcanic centre (Table 1; Figure 10; Matthews, 2008). The tephra's glass shards are characterised chemically by seven analyses and at present the tephra has only been detected at the type-site, Loughanascaddy Crannog, Ireland (Figure 2). It is, however, well constrained stratigraphically, occurring just below the Lairg A Tephra (6903 \pm 94 cal. BP), and $13 \mathrm{~cm}$ above sediment with a radiocarbon date of $7620 \pm 50{ }^{14} \mathrm{C}$ yrs. Bayesian age modelling 
suggests an age for this tephra of $8434 \pm 96$ cal. BP. There is some possibility therefore that the LAN1-325 Tephra may correlate with the proximal Slettahraun deposit in Iceland, which has been dated to c. 8000 yr BP (MacDonald et al., 1990; McGarvie et al., 1990). At present, however, the available chemical data for comparing the two are limited. Glass analyses for the LAN1-325 tephra are based on EPMA, and are published here for the first time (Supplementary Table S2), whereas the proximal analyses are based on whole-rock X-ray Fluorescence (XRF). Single grain glass analysis of the latter will be needed to provide more directly comparable data. Nonetheless, the age of the tephra means that it is has the potential to become a regionally valuable horizon for marking environmental responses to the 8.2 ka event.

\subsubsection{The Suduroy Tephra}

The Suduroy Tephra is a rhyolitic ash layer with a silicic Katla chemical signature (Table 1; Wastegård, 2002; Lane et al., 2012a). It was first identified at Hovsdalur on the Faroe Islands where it was dated to $8073 \pm 192$ cal. BP (Wastegård, 2002). In the British Isles, this tephra has been identified at two sites: Loch Laggan in the central Grampian Highlands (MacLeod, 2008) and Rubha Port an t-Seilich on Islay (Mithen et al., 2015; Figure 2). The tephra has also been identified in a series of North Atlantic marine deposits (Kristjánsdóttir et al., 2007; Gudmundsdóttir et al., 2012) as well as in sites in mainland Europe (Pilcher et al., 2005; Housley et al., 2012). There is some concern, however, that the Suduroy may represent reworked material from antecedent Vedde Ash deposits in some sites (Wastegård et al., 2018). However, this seems unlikely at Loch Laggan as a number of discrete tephras lie between what is hypothesised to represent the Vedde Ash based on stratigraphic superposition, and the glass-shard based chemically correlated Suduroy Tephra (MacLeod, 2008). At Rubha Port an t-Seilich the correlation is slightly more tentative as low concentrations of glass shards occur throughout the stratigraphic column suggesting a problem of reworked shards. Despite these concerns, if the Suduroy Tephra can be shown to represent primary fallout at sites to which it is traced, the age of the isochron means that like the LAN1-325 Tephra, the Suduroy Tephra may be particular useful in marking environmental response to the 8.2 ka event.

\subsubsection{The Breakish Tephra}

This is a rhyolitic ash layer which may originate from the Askja volcanic centre and its glass components exhibit distinctly high $\mathrm{TiO}_{2}$ (c. 0.49 wt \%) and $\mathrm{FeO}$ (c. 3.59 wt \%) values (Table 1). So far, it has been detected in the Loch Ashik sequence on Skye only, where it was reported as lying stratigraphically above the Saksunarvatn Ash (now considered to be the Havn-3 or 4 eruption, see section 3.5.6; Pyne-O'Donnell, 2007). At present the ash layer has 
not been dated directly, while the nearest match on the basis of glass composition is the Glen Garry Tephra (Pyne-O'Donnell, 2007; Lowe et al., 2016) which, being dated to $2176 \pm$ 164 cal. BP (Barber et al., 2008), is hence too young to be a viable correlative. Recently a number of other Askja-derived tephras have been identified in early-Holocene sequences, the Askja-L (c. 9400 cal. BP), and the Askja-H (c. 8850 cal. BP; Gudmundsdóttir et al., 2016). These are unlikely correlatives for the Breakish Tephra, however, as both exhibit glass chemical signatures very similar to those of the Askja-S, which the Breakish Tephra does not consistently match (Pyne-O'Donnell, 2007). Presently the potential usefulness of this ash layer within the British tephrostratigraphic framework is uncertain, and hence it has limited value until corroborative records can be found.

\section{Synthesis: an emerging tephrostratigraphic framework for the British Isles (16-8.0} ka $B P$ ) and its validation

The previous section presented, in order of stratigraphic superposition from oldest to youngest, the record of tephra layers detected in the British Isles for the period 16-8 ka BP. Establishing this order was guided initially by the relative positions of individual tephra layers with respect to the boundaries for the DS, WI, LLS and early Holocene stratigraphic units, while additional order could be imposed where two or more tephra layers are co-registered within the same sequence and stratigraphic unit, as in the case of the Borrobol and Penifiler Tephras, both of which are detected in a number of sediment records dating to the early WI (Supplementary Figure S1; Supplementary Table S1). Integration of the complete tephrostratigraphic dataset using common marker tephras leads to the regional tephrostratigraphic scheme presented in row F of Figure 12. Parts of this scheme should, however, be considered provisional in view of the points raised in section 3 over the origins of some layers, whether they represent primary fall events or, in the cases of those detected at a single site only, whether they have the potential to serve as regional isochrons. For these reasons, the tephras are coded in row F, Figure 12, to signify: (i) those considered to be based on the most robust glass analytical data, with consistent stratigraphic positions and well-defined ages ( $n=6$ ); (ii) those for which reasonably robust glass analytical data are available, but questions remain about their precise origins, stratigraphic integrity or age $(n=9)$; and (iii) those most in need of further investigation to test their potential to serve as regional isochrons in the British Isles $(n=11)$. It is tephras from these first two categories which we provisionally include within the formalised tephrostratigraphic framework (Table 4).

To validate and extend this regional framework, a number of stratigraphic constraints need to be taken into account. First, very few sites with tephra layers dating to the DS or to the 
DS-WI transition have been discovered in the British Isles so far, a reflection perhaps of the

1070

1071

1072

1073

1074

1075

1076

1077

1078

1079

1080

1081

1082 1098 geographical bias of recent tephrostratigraphical research, which has predominantly focused on sites in the Scottish Highlands. While parts of Scotland were deglaciated by c. 16.0 ka BP (Clark et al., 2012; Hughes et al., 2016; Ballantyne and Small, 2018), the current tephra record suggests that much of the Scottish Highlands did not become ice-free until, or marginally before, c. $14.0 \mathrm{ka} \mathrm{BP}$. This inference is indicated by the frequency with which the Borrobol Tephra is found close to the base of the earliest sediments to have accumulated in a number of lake basins (Walker and Lowe, 2017; Supplementary Figure S1), whereas in the Tirinie basin located in the Grampian Highlands, the younger Penifiler Tephra occupies this position (Candy et al., 2016). Thus far, the only terrestrial sites in the British Isles in which pre-WI tephra layers have been discovered are located on the Summer Isles in The Minch, off the north-west coast of Scotland, and on Orkney, north of the Scottish mainland, i.e. in parts of Scotland for which independent evidence indicates retreat of ice-sheet margins by or before 16.0 ka BP (e.g. Phillips et al., 2008; Ballantyne et al., 2012; Hughes et al., 2016). Hence the search for possible additional tephra records of pre-WI age in the British Isles may prove more profitable if focused on sites located in areas outside of the Scottish Highlands.

Only two tephra layers that date to within the WI have been proposed as viable regional isochrons: the Borrobol and Penifiler tephras which both date to between c. 14.19 and 13.9 ka BP. Whilst uncertainty surrounds the origin of the Penifiler tephra (section 3.3.1), there is nevertheless a degree of stratigraphic consistency in tephra records showing at least two shard peaks of Borrobol chemistry in the lower part of the WI. Additional stratigraphic markers help to constrain the age of these tephra layers for proxy environmental records from the British Isles are increasingly indicating evidence for two short-lived oscillations during the $\mathrm{WI}$, which are assumed to equate with the $\mathrm{Gl}-1 \mathrm{~d}$ and $\mathrm{Gl}-1 \mathrm{~b}$ events (column $\mathrm{A}$, Figure 12) in the Greenland stratotype record (e.g. Brooks and Birks, 2000; Marshall et al., 2002; Lang et al., 2010; Watson et al., 2010; van Asch et al., 2012; Whittington et al., 2015; 1097 Brooks et al., 2012; 2016). In a number of tephra records, one of the peaks (usually the more prominent) clearly pre-dates the oscillation equated with $\mathrm{Gl}-1 \mathrm{~d}$, while the younger, less prominent peak lies within this interval (Matthews et al., 2011; Brooks et al., 2012; 2016).

Some of the evidence on which these stratigraphic relationships are based has, however, relied on correlations resting entirely on lithostratigraphic criteria, represented by loss-onignition (LOI) data (e.g. Lowe et al., 1999; Turney et al., 2006; Pyne-O’Donnell, 2007; PyneO'Donnell et al., 2008). Although the lithostratigraphic changes within the $\mathrm{WI}$ are clearly evident in some sequences, they are poorly developed in others (cf. columns B and C, 
Figure 12). This inconsistency could reflect the influence of local factors that acted to dampen or enhance the impacts of the environmental conditions that caused these lithostratigraphic changes, for example, the degree of shelter or exposure afforded to different catchments, or poor resolution of these sedimentary features due to very low rates of sedimentation. To complicate matters further, some sequences show evidence for at least six lithological sub-units within the WI interval (e.g. column B, Figure 12 in which the more minerogenic layers are numbered 1-3), and hence the possible occurrence of three shortlived climatic oscillations rather than two (see Whittington et al., 2015; Candy et al., 2016; Walker and Lowe, 2017). Finally, it cannot be assumed that these lithological changes necessarily reflect climatic impacts. Short-lived increases in the rate of minerogenic sediment supply to lake basins could reflect localised soil or land disturbance caused, for example, by sediment or rock failures. A more secure basis, therefore, for assessing the significance of these lithological changes would be by inclusion of palaeoclimate proxies in site investigations, for example the analysis of stable oxygen isotope variations (column $D$, Figure 12) or chironomid assemblages (column E, Figure 12), but detailed records of this type that extend through the Lateglacial and early Holocene are presently available for only a handful of records in the British Isles (e.g. Marshall et al., 2002; Brooks et al., 2012; Whittington et al., 2015; Candy et al., 2016). Nevertheless, the few lake records that are presently available that combine tephrostratigraphic with palaeoclimatic data do support the view that two Borrobol-type tephra peaks dating to the early $\mathrm{WI}$ are distinguishable by stratigraphic position relative to a short-lived climatic oscillation provisionally equated with the Gl-1d event (Brooks et al., 2016).

One of the main challenges facing the tephrostratigraphic scheme is the further refinement and validation of tephras located between the LLS-Holocene transition and c. 8.0 ka BP. Fifteen tephra layers have been proposed for this interval so far (section 3.5; Figure 12; Table 4), some with very similar major and minor element glass compositions, some in close stratigraphic proximity, and some sharing overlapping age ranges. In addition, there is a likelihood that a proportion of these tephra layers, where present, will be conflated together in a single horizon. This is due to the marked warming at the start of the Holocene, the expansion of higher plant communities and the consequential stabilisation of catchment soils, all of which would have led to a reduction in the sediment supply rate to lake basins compared with the preceding Lateglacial period (e.g. Brauer et al., 1999). Furthermore, in most lake basin sites in the British Isles, the early Holocene deposits lack the clear lithostratigraphic markers that characterise Lateglacial sediment sequences (Column B and $\mathrm{C}$, Figure 12). This means that other indictors must play a more prominent role in refining the stratigraphic superposition of tephra layers. For example, greater reliance may be placed 
upon those tephras with distinctive glass chemical compositions or shard morphology as key markers, such as the Hässeldalen, Askja-S and traditionally the Saksunarvatn Ash, although the robustness of the latter is now doubtful. Recourse can also be made to other 'proxy' stratigraphical information-for example, pollen-stratigraphic records for the early Holocene throughout much of the British Isles reflect a characteristic plant colonisation sequence dominated successively by Empetrum, Juniperus, Betula and Betula-Corylus (Walker, 1984; Birks, 1989). In records obtained from sites in the Scottish Highlands, the Askja-S Tephra is consistently found within the upper part of the Juniperus phase, whereas deposition of the An Druim Tephra post-dates the local establishment of Betula-Corylus woodland (Ranner et al., 2005; Kelly et al., 2017; Lowe et al., 2017). Whether these relationships hold for other parts of the British Isles is unclear, however, as the process of plant colonisation over a wider area is likely to have been time-transgressive (Tipping, 1987; Birks, 1989; Huntley, 1993; Normand et al., 2011).

The British Isles represent the most intensively studied area for LGIT-aged cryptotephra anywhere, but it is clear from the above sections that the tephrostratigraphic scheme presented here is still in need of further refinement (Figure 12; Table 4). Even though future tephra studies will have a variety of specific goals, those offering the greater potential for improving the tephrostratigraphic scheme presented here are likely to be those based on sedimentary records that are: (i) capable of analysis at high stratigraphic and temporal resolution, allowing closely timed ash-falls to be clearly separated and sequenced, such as the Askja-S and Ashik tephras; and (ii) part of multi-proxy programmes of research, which allow the local and wider climatic and environmental context at the time of deposition to be assessed. Critical to this is the inclusion of palaeoclimatic reconstructions, enabling the alignment of tephra layers with local or regional climatostratigraphic events to be established (Figure 12). It should not be assumed, however, that these records need to be located within the British Isles as sites with better resolution and more secure stratigraphic settings may be available elsewhere in Northern Europe. A possible weakness that needs to be noted, however, is that of circular argument where, on the one hand, tephra layers are used as stable marker horizons to test for asynchronous climatic behaviour, while climatostratigraphic boundaries are used to judge the isochronous nature of tephra layers, an example being that of the Borrobol and Penifiler tephras (see section 3.3.1; see also studies on this topic by Newnham and Lowe, 1999). In view of the growing evidence from Europe that suggests climatic changes during the period c.16-8 ka were time-transgressive (e.g. Lane et al., 2013; Rach et al., 2014; Muschitiello and Wohlfarth, 2015), care needs to be exercised when adopting this approach. Likewise the use of local pollen-stratigraphic boundaries for correlation purposes, as in the example given above of the Askja-S Tephra, is 
also potentially problematic. This dilemma could be avoided if all tephra layers were

1181

1182

1183

1184

1185

1186

1187

1188

1189

1190

1191

1192

1193

1194

1195

1196

1197

1198

1199

1200

1201

1202

1203

1204 chemically distinct, stratigraphically separable and reliably dated with narrow age ranges, but, as illustrated in section 3, such an ideal scenario is far from the case. Thus the process of establishing the consistent stratigraphic context and isochronous nature of cryptotephra layers will continue to be an iterative one.

\section{Future targets and prospects}

The tephrostratigraphic scheme outlined in Figure 12 reflects the current available evidence in the British Isles, but aspects of the scheme require further refinement and to aid this we identify reference records for each proposed tephra isochron, including those that cannot yet be integrated confidently into the framework (Table 4). Most of these reference records are provisional and were selected using a combination of criteria, notably the resolution and magnitude of peak shard concentrations, the robustness of supporting glass analytical data, and the precision and reliability of associated age estimates. Note that an individual reference record is not necessarily that from which the proposed isochron or tephra layer was first recognised in the British Isles, because later discoveries may be considered superior. For example, the Tirinie sequence is selected as the reference record for the Penifiler Tephra in the British Isles for two mains reasons: (i) it has a better resolved shard peak than is the case for the Druim Loch record from Skye, which is located close to the village of Penifiler, after which the tephra is named; (ii) the site has robust palaeoclimatic data available; and (iii) the collective stratigraphic evidence for the Tirinie sequence provides the strongest argument against the Penifiler Tephra being derived by reworking of the Borrobol Tephra (see section 3.3.1), at least in this instance, since the onset of sediment accumulation in the Tirinie basin post-dates deposition of the Borrobol Tephra (Candy et al., 2016). In due course, more secure reference records may emerge from investigations of new sites, or through more rigorous re-examination of previously studied sequences that, for example, are in need of analysis at a higher stratigraphic or temporal resolution, or for which glass shards are currently weakly characterised. To this end, development of reference records and the tephrostratigraphic framework as a whole will be enhanced by addressing the following issues: (i) spatial and stratigraphic sampling biases; (ii) glass-shard analytical data, both for major and trace elements, and the need for improved resolution and scrutiny of existing compositional data, and (iii) ongoing refinement of tephra age estimates.

Studies over the past 25 years have revealed a wealth of tephrostratigraphic data for British LGIT sediment sequences, but knowledge gaps remain. These include finding additional isochrons and establishing the full geographic ranges over which they are traced. In this 
context, Scotland has been the most intensely studied area in the British Isles for tephra have so far been explored for their tephra content (Walker and Lowe, 2017), while the comparable ratios for sites in England, Wales and Ireland are much lower (Figure 2; Supplementary Figure S1). Given the relative abundance of mid-late Holocene tephra detected in other areas of the British Isles (Swindles et al., 2011; Plunkett and Pilcher, 2018), it is probable that more tephra layers await discovery, including those dating to the LGIT. Particularly intriguing in this respect are tephras that have been detected in a single site only, such as the Roddans Port and LAN1-325 tephras in Ireland and the recent discovery of 'ultra-distal' tephras from North American centres. It is not clear whether these sparse records reflect a very limited impact of the corresponding ash clouds in the British Isles, a failure to detect these layers in other records, or both.

Pertinent to this point is the strategy adopted when investigating the glass shard content of sediment sequences. In some cases records have not been investigated in full, either because research questions were focused on specific age intervals, or because certain tephras were seen as more important than others and were preferentially targeted, or because sampling resolution or methods were not sufficient to detect cryptotephras. Understanding the purpose and sampling limitations behind individual tephrostratigraphic studies is therefore important when synthesising records to construct a regional tephrostratigraphic framework. In some previous records there has been a tendency to focus attention on selected key marker horizons, such as the Vedde and Saksunarvatn ash layers (e.g. Wastegård 2000; Bramham-Law et al., 2013). These tephra are understood to represent the most explosive and voluminous eruptive events that occurred during the period 16-8 ka, but other tephra which have been explored less assiduously may prove to serve as equally important isochrons, with dispersal ranges possibly just or as nearly widespread. The recent eruptions of Eyjafjallajökull and Grímsvötn in Iceland (Davies et al., 2010; Stevenson et al., 2012; 2013) have demonstrated that relatively small to moderate eruptions can have much greater dispersal ranges than those presently recognised in the palaeo-tephra record. This raises the question as to whether important ash layers are being overlooked by selective low resolution sampling methods and the over emphasis and exploration of 'key marker' horizons (Timms et al., 2017). Given this concern, more studies are now adopting contiguous high resolution sampling strategies as routine practice, most being rewarded with improved tephrostratigraphic resolution and discrimination, and more secure tephra-linkages than coarse sampling strategies tend to yield (e.g. MacLeod 2008; Matthews et al., 2011; Timms et al., 2017; 2018). It follows that if the tephrostratigraphic scheme and its applications are to be optimised, this practice needs to be more commonly applied. 
In other cases the nature of negative information (the absence of glass shards) is not always investigations have been carried out but no tephra (glass) was found. In times of the latter, it is recommended that such negative findings are always reported, as they are particularly valuable for: (i) assessing the efficiency of different approaches employed for tephra detection and extraction; (ii) reconstructing the geographical distribution ('footprints') of individual tephra isochrons, and (iii) evaluating the taphonomic and other factors that influence the deposition and preservation of volcanic glass shards. Negative results, where known, have been compiled for this review (Supplementary Figure 1; Supplementary Table 1), and are beginning to be reported more routinely (e.g. Wastegård et al., 2000; van Asch et al., 2012; Jones et al., 2017).

Thorough tephrostratigraphic investigations should be coupled with robust chemical determinations conducted at a comparable stratigraphic resolution (see Lowe, D. et al., 2017). However, the greater scrutiny this enables will inevitably result in exposing further levels of complexity for, as outlined in earlier sections of this paper, the LGIT tephrostratigraphic record is already populated with tephra layers that share closely similar or indistinguishable major element signatures. Whether this similarity extends to trace element compositions remains to be widely tested, but as recommended elsewhere, when major elements prove equivocal trace elemental analyses should be prioritised (e.g. Lowe 2011, Lowe, D. et al., 2017). This contribution has also shown the frequency with which a single shard concentration peak may include shards with a range of different chemical (major element) compositions (Supplementary Table S2), raising the question of whether even finer resolution studies are required to resolve such complexities, including, for example, high-resolution imaging techniques to better understand the local depositional context (see Griggs et al., 2015). However, this greater scrutiny may only serve to highlight the scales at which mixing processes occur, if shards are already known to be spread over cm's, further examination at $\mathrm{mm}$ scales, or finer, may not yield further useful information. It may be required, therefore, that future studies focusing on resolving regional tephrostratigraphies be conducted in records that are less susceptible to taphonomic processes, or in records where stratigraphic integrity can be reliably demonstrated e.g. annually laminated records. Whatever the cause, repeating chemical signatures are probably the greatest challenge to the refinement of any tephrostratigraphic scheme, and may only be resolved by more comprehensive assays of the major, minor and trace element compositions of the glass components of each tephra layer, coupled with a detailed understanding of the stratigraphic context (Lowe, 2011; Lowe, D. et al., 2017). 
A further target for future research will be refinement of the age estimates assigned to each tephra isochron, for a number of those included in the tephrostratigraphic framework outlined here presently have wide ranges or conflicting age estimates. Examples include the Penifiler Tephra (see section 3.3.1), the Askja-S Tephra (section 3.5.3) and the Saksunarvatn Ash, this last example made more complicated by the likelihood that several closely-spaced eruptions have become conflated under the single name (section 3.5.6). Since these age

1297

1298

1299

1300

1301

1302

1303

1304

1305

1306

1307

1308

1309

1310

1311

1312

1313 uncertainties compromise the use of tephra isochrons for the development or testing of age models based on other methods, the search for new sites which offer opportunities for significantly reducing the uncertainties must be a priority. In this regard we advocate the RESET approach (Bronk Ramsey et al., 2015; Lowe et al., 2015), where all the chronological information associated with an individual tephra isochron is evaluated using Bayesian probabilistic modelling to generate an optimised age estimate. This has the potential advantage, depending on the number and uncertainty ranges of the dates available, that no single erroneous estimate will heavily bias the outcome, although it is recommended that this is only applied to sequences where correlations are robust and unequivocal.

Finally, a more fully developed and secure tephrostratigraphic scheme potentially can yield a number of dividends, not only in terms of improved dating and correlation of sedimentary sequences, but also with respect to important palaeoenvironmental questions. For example, it is noticeable that for the period 16-11.7 ka, only four clearly-defined tephras have been detected in sites in the British Isles (the Dimna, Borrobol, Penifiler and Vedde), although there are tentative signs that others may be added in due course. This record contrasts starkly, however, with the much higher number of tephra layers detected in the shorter period between 11.7 and $8 \mathrm{ka}$ (Figure 12). The question that arises is what may have caused this difference. One possibility is an increased frequency and perhaps magnitude of volcanic eruptions in Iceland during the early Holocene. Tephrochronological research in Iceland is increasingly pointing to a connection between the frequency and magnitude of volcanic activity on the one hand, and glacial unloading due to a warming climate on the other (e.g. Maclennan et al., 2002; Carrivick et al., 2009; Sigmundsson et al., 2010). However, an alternative explanation for this contrast in the British tephrostratigraphical record would be a major change in climatic regime in the North Atlantic region between the end of the Pleistocene and start of the Holocene, which resulted in more ash plumes being driven from Iceland towards the British Isles in the latter period. It is difficult on present evidence to support either argument. There are also apparent notable differences in the trajectories and dispersal limits of individual tephra layers, but these may be misleading due 
to geographical bias in the distribution of sites from which detailed tephrostratigraphic preferentially targeted. Hence caution should be exercised when drawing conclusions about the factors that influenced tephra dispersal patterns (e.g. magnitude of eruption; wind strength and direction; seasonal climatic conditions) until more robust tephra 'footprints' over Europe become available.

\section{Conclusions and recommendations}

The synthesis presented here, obtained from 54 sites and including 26 well established or potential eruptives, indicates the British Isles to be one of the most intensely studied regions in the world for cryptotephra deposition. This network of sites offers an exceptional opportunity for testing the timing of abrupt climatic transitions and their environmental, archaeological and geological impacts during the LGIT. It is hoped that the tephra framework presented here will, in time, help to resolve some of the long standing debates concerning the precise chronology of events in the British Isles and Europe during the LGIT (e.g. Lowe, 2001; Palmer and Lowe, 2017; Peacock and Rose, 2017). Tephrochronology has the potential to emerge as a ubiquitous connecting and dating method to support late Quaternary palaeoenvironmental investigations, and is capable of enhancing and testing more traditional geochronological techniques, given sufficient integration and development. A systematic search for tephra in many more European palaeoclimate investigations should foster more robust correlations, and allow the reconstruction of environmental changes with a greater degree of finesse than has been achieved hitherto. It is essential therefore that local tephra frameworks are developed in new regions, and particularly in areas where little tephra exploration has been undertaken to date. As previously noted, very few tephras of LGIT age have been identified in England, Wales and Ireland, while the level of such enquiry is even lower for many other European countries.

Whilst it is now possible to precisely link sequences from the British Isles to Greenland, Scandinavia, continental Europe and the Mediterranean region, with further development, the potential for much wider trans-continental synchronisation appears to be within grasp. The recent discovery of the Glacier Peak B Tephra in Scotland (Pyne-O'Donnell and Jensen, 2018) and the coeval discovery of the Glacier Peak and Mount St Helens J eruptions at Finglas River (reported here) are significant finds which adds to the growing body of literature describing ultra-distal tephras in the British Isles (Jensen et al. 2014; Plunkett and Pilcher, 2018). Studies focused on mid to late Holocene records in Europe and the North Atlantic margin are already reporting the discovery of multiple trans-continental ashes from a 
variety of volcanic centres (Van der Bilt et al. 2017; Watson et al., 2017; Cook et al., 2018b); there is no good reason, therefore, why tephras from these centres should remain

- Contiguous sampling of sedimentary records at a coarse stratigraphic resolution, followed by more intensive re-sampling at a finer resolution, is an efficient approach for achieving a thorough assessment of a sites (crypto-)tephra content; this approach, however, promotes coverage over detail, with the potential result that eruptions represented by trace amounts of cryptotephra could be overlooked; this is particularly evident where more 'minor' (crypto-)tephras coincide with eruptions that produce more copious ash-fall; refined contiguous sampling at high stratigraphic resolution may therefore be required to detect and resolve these instances of conflated tephra layers (see Timms et al., 2017, 2018);

- The chemical classification of tephra layers has traditionally relied on the measurement of major and minor element ratios, an approach which has often proved inadequate as a discriminatory tool, especially for distinguishing between successive tephras from the same volcanic source (as in the case of the Borroboltype tephras discussed here); for greater discriminatory power, therefore, recourse to the analysis of trace (including rare-earth) elements should perhaps become more routine;

- The development of a (crypto-)tephrostratigraphy is best conducted in parallel with detailed litho-, bio- and climatostratigraphic investigations, particularly where these provide regionally consistent 'zones' which can aid in the interpretation and correlation of tephras; 
1399

1400

1401

1402

1403

1404

1405

1406

1407

1408

1409

1410

1411

1412

1413

1414

1415

1416

1417

1418

1419

1420

1421

1422

1423

- Where possible, tephra layers should be dated independently and all chronological information for individual isochrons integrated using a Bayesian age modelling procedure;

- The primary limitation in developing a regional (crypto-)tephrostratigraphic framework is the time needed to detect, extract, chemically fingerprint and independently date glass shards representing the individual tephra layers, and hence further experimental work that leads to significant paring of the laborious procedures involved would greatly augment the potential applications of (crypto)tephrochronology.

The framework proposed here marks a major step in the consolidation of tephrostratigraphic data dating to the LGIT in NW Europe. The scheme is, however, a work in progress and we hence encourage efforts to further refine the scheme, if possible by adopting the above recommendations, in order to enhance its potency as an aid for the correlation and dating of events during the LGIT.

\section{Acknowledgements}

The authors would like to express their gratitude to the numerous researchers whose hard work over the past thirty years has formed the basis of this review. In particular we'd like to thank all those former MSc Quaternary Science students at Royal Holloway who have conducted exploratory tephrostratigraphic investigations at a number of sites in the British Isles and whose provisional results have been compiled here. A special note of thanks, must also go to Elaine Turton (RHUL), Katy Flowers (RHUL), Dr Sean Pyne-O'Donnell, Dr Mark Hardiman (Portsmouth), Dr Paul Lincoln (RHUL) and Dr Chris Hayward (Edinburgh), whose advice and technical assistance given to many researchers over the past few years has proved invaluable to the development of this tephrostratigraphic scheme. In addition, we would like to extend our thanks to Jonathan Moles (OU) for information on the Tindfjallajökull and Torfajökull volcanoes, and also to Professor David Lowe (Waikato) and Dr Peter Abbott (Bern/Cardiff) for agreeing to review the manuscript and for providing thorough and constructive comments. Some of the data compiled in this review was funded by the RAPID Climate Change research programme (NERC project number: NE/C509158/1) awarded in 2005 and the RESET project (NERC project number: NE/E015905/1) awarded in 2007. RT would like to acknowledge funding from Royal Holloway University of London (RHUL) in the form of a Reid scholarship, and thank the Quaternary Research Association (QRA) for the receipt of a 'New Research Workers Award' which assisted in the collection and analysis of 
1436 Orcadian lake records reported here. IM completed the work on LAN1-325 while in receipt of a Reid scholarship (RHUL) and funded by Archaeological Development Services Ltd. JL acknowledges the Leverhulme Trust (project number: EM-2014-025) for financial support for some of the field and laboratory results in Scottish sites presented herein. This paper is an output of the EXTRAS project 'EXTending tephRAS as a global geoscientific research tool stratigraphically, spatially, analytically, and temporally' led by the International focus group on tephrochronology and volcanism (INTAV) of the International Union for Quaternary Research (INQUA). 


\section{Figure Captions}

Figure 1

Overview of the British Isles and location of volcanic centres discussed in text that contribute to the British and European tephra frameworks.

Figure 2

Summary of LGIT tephrostratigraphic sites in the British Isles. Note: only sites where glass shards from tephras have been chemically characterised are included here. Each site is represented by a segmented chart with the coloured sections corresponding to the presence of a particular tephra. A coloured section affixed with a ? symbol indicates a degree of uncertainty with the correlation. A ? symbol overlapping several segments signifies a likely correlation to one of those tephra, but at present a correlation is indeterminable. $A$ complementary schematic is presented in Supplementary Figure S1 which includes individual site stratigraphic data, negative findings of glass shards and sites whereby tephra have been assigned on the premise of stratigraphy. A tabulated summary of tephra correlations and sampling strategies can be found in Supplementary Table S1. Glass-shard compositional analyses used to make these correlations can be accessed from Supplementary Table S2.

Figure 3

Last Termination or Last Glacial to Interglacial Transition (LGIT) event stratigraphy for Greenland, NW Europe, and the British Isles. The Greenland event stratigraphy is divided into Stadials (GS: cold phase), and Interstadials (GI: warm phase), with comparable, but not necessarily synchronous phases identified in European and British climate archives. GI-1 is divided into seven subunits, with (GI-1d, GI-1c2, GI1b) reflecting short lived cold events punctuating an otherwise comparatively warm interval (GI-1e, GI-1c3, GI-1c1, GI-1a; Björck et al. 1998; Rasmussen et al. 2006). In the early Holocene a number of similar revertence episodes are also identified, most notably the $11.4 \mathrm{ka}$ event (Pre-Boreal Oscillation), $9.3 \mathrm{ka}$ event and the 8.2 ka event. The example stratigraphy (Loch Etteridge) shows how these climatic events can be expressed in the sedimentological record, a pattern which can be recognised in basin sediments across the British Isles (Walker and Lowe, 2017).

Figure 4

Selected chemical bi-plots of non-normalised glass compositional data from Dimlington Stadial tephras identified in Scottish sequences. Correlations can be made to the Dimna Ash (Koren et al., 2008) and the Borrobol-type tephra series. Low CaO wt \% values exhibited by 
glass analyses of the Dimlington Borrobol-type tephra negates a correlation to the

Greenland GS-2.1 Borrobol-type tephra identified by Cook et al. (2018). The Dimlington Borrobol-type tephra is therefore given the provisional name of 'Tanera Tephra' after the island where this tephra is presently most clearly defined. The site-specific glass analytical data used for this figure is included in Supplementary Table S2. References for the chemical envelopes are listed in Supplementary Table S3.

Figure 5

Schematic showing the inconsistent stratigraphic interpretation of the Borrobol-type tephra series at the site of Borrobol, NW Scotland. Records from: A) Turney et al., (1997); B) PyneO’Donnell, (2007); C) Lind et al., (2016).

Figure 6

Selected chemical bi-plots of non-normalised glass compositional data showing the similarity between the basaltic component of the Penifiler Tephra identified at Loch Ashik and the NGIP-1573m Tephra. These tephra have an overlapping age estimate and share indistinguishable glass compositions that match with those of the Katla volcanic centre and of the Vedde Ash-type tephra series. The Loch Ashik glass analyses used for this figure are included in Supplementary Table S2. References for the chemical envelopes are listed in Supplementary Table S3.

\section{Figure 7}

Selected chemical bi-plots of non-normalised glass compositional data for tephras identified at Finglas River. Three glass compositional populations can be identified, group A matches with the Glacier Peak G Tephra, shard B matches with the Mount St Helens J Tephra and shard C matches with the Borrobol-type series. The Finglas River glass analyses used for this figure are included in Supplementary Table S2. References for the chemical envelopes are listed in Supplementary Table S3.

Figure 8

Selected chemical bi-plots of non-normalised glass compositional data comparing the Roddans Port and LAS-1 tephras with regional marker horizons of equivalent Windermere Interstadial (WI) age. Some similarity can be observed between the analyses of the Roddans Port B and LAS-1(B) glass shards with those from North American centres (i.e. Glacier Peak and Mount St Helens), however, this similarity is not consistent across all major and minor elements. The Roddans Port and LAS-1 glass analyses used for this figure are included in 
1546 Supplementary Table S2. References for the chemical envelopes are listed in

Supplementary Table S3.

1548

Figure 9

Selected chemical bi-plots of non-normalised glass compositional data from the Abernethy Tephra plotted against glass analyses of the Vedde Ash and Windermere Interstadial (WI) Borrobol-type tephras. It is clear that in two of the three sites where the Abernethy Tephra has been analysed, the layer in question has returned a bi-modal glass compositional signature. The site-specific glass analyses used for this figure are included in Supplementary Table S2. References for the chemical envelopes are listed in Supplementary Table S3.

Figure 10

Chemical bi-plot ( $\mathrm{MgO}$ vs. $\mathrm{TiO}_{2}$ ) of non-normalised glass analyses from tephras originating in the Torfajökull volcanic centre during the early Holocene. An enrichment in $\mathrm{TiO}_{2}, \mathrm{Al}_{2} \mathrm{O}_{3}$, $\mathrm{MgO}$ and $\mathrm{CaO}$ is noted in postglacial rhyolitic rocks from this centre (McGarvie et al., 1990). This trend seems to apply to a the majority of the Torfajökull-type tephras identified in the British Isles, however, the An Druim-Høvdarhagi Tephra seems to partially reverse this, exhibiting both a 'less-evolved' and 'more-evolved' bi-modal glass composition. The site specific glass analyses used for this figure are included in Supplementary Table S2.

References for the chemical envelopes are listed in Supplementary Table S3.

\section{Figure 11}

Chemical bi-plot ( $\mathrm{CaO}$ vs. $\mathrm{MgO}$ ) of non-normalised glass analyses from tephras correlated to the Saksunarvatn 10-ka series in the British Isles. The 'Saksunarvatn Ash' at Loch Ashik has been reassigned to the Havn-3/ Havn-4 Tephra on the premise of characteristically 'low' MgO wt \% values (Wastegård et al., 2018). The 'Saksunarvatn' Ash layer identified at Crudale Meadow by Bunting (1994) exhibits a bi-modal glass composition, group A correlates to the Grímsvötn volcanic centre, whilst group B shows a greater affinity to glass analyses of the Veiðivötn-Bárðarbunga system. The site specific glass analyses used for this figure are included in Supplementary Table S2. References for the chemical envelopes are listed in Supplementary Table S3.

Figure 12

Regional tephrostratigraphic scheme for the British Isles. A) GICC05 $\delta^{18} \mathrm{O} \%$, and regional event stratigraphy (Rasmussen et al., 2006). B) Crudale Meadow sediment stratigraphy; note the three numbered minerogenic bands within the Interstadial marl sediments (Timms et al., 2018). C) Tanera Mòr 1 sediment stratigraphy, note the absence of any 
sedimentological change through the Interstadial sediments (Timms, 2016). D) Oxygenisotope record from Crudale Meadow (Whittington et al., 2015). E) Chironomid derived summer temperature reconstruction from Muir Park Reservoir (Brooks et al., 2016). F) Regional tephrostratigraphic scheme for the British Isles, bar length denotes degrees of confidence: (i) those considered to be based on the most robust glass analytical data, with consistent stratigraphic positions and well-defined ages $(n=6)$; (ii) those for which reasonably robust glass analytical data are available, but questions remain about their precise origins or age ( $n=9)$; and (iii) those most in need of further investigation, to test their potential to serve as regional isochrons $(n=11)$. Note: the alignment of the individual proxy series with the GICC05 event stratigraphy is not intended to illustrate climatic synchronicity between the records.

\section{Table Captions}

Table 1

Combined non-normalised glass-shard analytical data of tephras identified in the British Isles dating to the Last Glacial to Interglacial Transition (LGIT c. 16-8 ka BP). The value shown in the 'Number of sites' row relates only to those locations where correlations are secure: see Supplementary Table S1 for further details on the number of tentative correlations for each tephra. Mean glass data derived from: Roberts, (1997); Turney et al. (1997); Darville, (2011); Davies et al. (2001); Mackie et al. (2002); Ranner et al. (2005); Pyne-O'Donnell, (2007), Matthews, (2008); Pyne-O'Donnell et al. (2008); Matthews et al. (2011); Lane et al. (2012a); Weston, (2012); MacLeod et al. (2015); Mithen et al. (2015); Lind et al. (2016); Timms, (2016); Jones et al. (2017); Kelly et al. (2017); Lowe et al., (2017); Timms et al. (2017, 2018); Lowe et al. (in prep). Glass compositional data are available in full from Supplementary Table S2.

Table 2

List of sites in the British Isles where the Borrobol $(n=13)$, Penifiler $(n=15)$ and CRUM1 597 tephras have been proposed. Based on major and minor element analyses of glass shards, 13 sites are understood to contain the Borrobol Tephra, 15 sites the Penifiler Tephra and 2 sites the CRUM1 597 Tephra. A further 3 Borrobol, 4 Penifiler and 4 CRUM1 597 records are tentatively proposed based on stratigraphic superposition and are indicated by a ? symbol.

Table 3 
Sites from which glass analyses have been obtained and used to claim the presence of the

1620

1621

1622

1623

1624

1625

1626

1627

1628

1629

1630

1631

1632

1633

1634

1635

1636

1637

1638

1639

1640

2631

'Abernethy Tephra'. In all cases except the Glen Turret Fan record, a mixed chemical assemblage has been revealed, implicating the possibility of reworking and amalgamation of older tephra deposits.

Table 4

Summary of tephra isochrons included, and those not yet considered suitable for inclusion, within the British Isles tephrostratigraphic scheme (c. 16-8 ka BP). Also shown are reference records for each tephra; these are the sites in the British Isles which each tephra is currently best represented at. Categories i, ii and iii are explained in the text.

\section{Supplementary Files}

\section{Supplementary Figure S1}

Summary of LGIT tephrostratigraphic sites in the British Isles. Each site, where possible, is represented by a tephra concentration diagram and loss-on-ignition (LOI) or calcium carbonate $\left(\mathrm{CaCO}_{3}\right)$ signal. Where multiple investigations have been conducted at a single site, those profiles which best represent the tephrostratigraphic results have been selected. A solid coloured bar denotes a correlation made using glass-based analyses, a dashed coloured bar signals a correlation made on the premise of stratigraphic superposition. A band featuring two alternating represents an uncertain correlation between two tephras with glass components of indistinguishable major and minor element chemistry. A ? symbol indicates a degree of uncertainty with the correlation. A list of references is provided in Supplementary Table S1. Glass compositional data used to make these correlations can be accessed from Supplementary Table S2. This figure is best viewed in its original A0 format.

\section{Supplementary Table S1}

Compilation of published and unpublished reports of tephra records in the British Isles dating to the LGIT. The numbered 'Ref' column indicates the order in which the sites are numbered in Supporting Figure S1. The green infill in the four chronostratigraphic columns show which LGIT chronozone units are present at each site, whereas ticks illustrate whether a tephrostratigraphic study has been undertaken. Ticks associated with the tephra columns indicate which tephra layers have been identified/proposed for each site. Black boxes surrounding a ticked tephra indicate that the horizon forms a visible tephra layer. An orange infill indicates that the basaltic end member of the tephra is present - this is only relevant for the Vedde Ash, Ashik Tephra and Penifiler Tephra. A ? symbol indicates that there is a degree of uncertainty with the interpretation, with the details of such listed in the 
1656 corresponding 'comments' column. A * symbol in association with the site co-ordinates denotes an approximate position only and not the exact core location.

\section{Supplementary Table S2}

Database of major and minor element analyses for glass shards reported from tephra records in the British isles dating to the LGIT (c. 16-8 ka BP). Data presented as raw (unnormalised) and normalised. 


\section{References}

Abbott, P.M. and Davies, S.M. 2012. Volcanism and the Greenland ice-cores: the tephra record. Earth-Science Reviews 115,173-191.

Abbott, P.M., Griggs, A.J., Bourne, A.J., Chapman, M.R., Davies, S.M. 2018. Tracing marine cryptotephras in the North Atlantic during the last glacial period: Improving the North Atlantic marine tephrostratigraphic framework. Quaternary Science Reviews 189, 169-186.

Albert, P. 2007. Tephrostratigraphical investigation of Loch Etteridge: stratigraphical uncertainties. Unpublished MSc Thesis, University of London.

Bakke, J., Lie, Ø., Heegaard, E., Dokken, T., Haug, G.H., Birks, H.H., Dulski, P. Nilsen, T. 2009. Rapid oceanic and atmospheric changes during the Younger Dryas cold period. Nature Geoscience 2, 202-205.

Ballantyne, C.K. 2002. Paraglacial geomorphology. Quaternary Science Reviews 21, 19352017.

Ballantyne, C. K. 2010. Extent and deglacial chronology of the last British-Irish Ice Sheet: implications of exposure dating using cosmogenic isotopes. Journal of Quaternary Science $25,515-34$.

Ballantyne, C.K. 2012. Chronology of glaciation and deglaciation during the Loch Lomond (Younger Dryas) Stade in the Scottish Highlands: implications of recalibrated 10Be exposure ages. Boreas 41, 513-526.

Ballantyne, C.K., Harris, C. 1994: The Periglaciation of Great Britain. Cambridge: Cambridge University Press.

Ballantyne, C.K., Small, D. 2018. The last Scottish ice sheet. Earth and Environmental Science Transactions of the Royal Society of Edinburgh, 1-39 (in First View: doi.org/10.1017/S1755691018000038)

Ballantyne, C.K., Schnabel, C., Xu, S. 2009. Readvance of the last British-Irish ice sheet during Greenland interstade $1(\mathrm{Gl}-1)$ : the Wester Ross readvance, NW Scotland. Quaternary Science Reviews 28, 783-789. 
Barber, K., Langdon, P., Blundell, A. 2008. Dating the Glen Garry tephra: a widespread late-

environment, vegetation and human settlement on Catta Ness, Lunnasting, Shetland. Journal of Ecology 80, 241-273.

Bertrand, S., Daga, R., Bedert, R., Fontijn, K. 2014. Deposition of the 2011-2012 Cordón Caulle tephra (Chile, $40^{\circ} \mathrm{S}$ ) in lake sediments: Implications for tephrochronology and volcanology. Journal of Geophysical Research: Earth Surface 119, 2555-2573.

Bickerdike, H.L., Evans, D.J.A., Stokes, C.R. Ó Cofaigh, C. 2018. The glacial geomorphology of the Loch Lomond (Younger Dryas) Stadial in Britain: a review. Journal of Quaternary Science 33, 1-54.

Birks, H.J. 1989. Holocene isochrone maps and patterns of tree-spreading in the British Isles. Journal of Biogeography 503-540.

Birks, H.H., Gulliksen, S., Haflidason, H., Mangerud, J., Possnert, G. 1996. New radiocarbon dates for the Vedde Ash and the Saksunarvatn Ash from western Norway. Quaternary Research 45,119-127.

Björck, S., Walker, M.J., Cwynar, L.C., Johnsen, S., Knudsen, K.L., Lowe, J.J., Wohlfarth, B. 1998. An event stratigraphy for the Last Termination in the North Atlantic region based on the Greenland ice-core record: a proposal by the INTIMATE group. Journal of Quaternary Science 13, 283-292.

Björck, J., Wastegård, S. 1999. Climate oscillations and tephrochronology in eastern middle Sweden during the last glacial-interglacial transition. Journal of Quaternary Science 14 (5), 399-410.

Björck, S., Muscheler, R., Kromer, B., Andresen, C.S., Heinemeier, J., Johnsen, S.J., Conley, D., Koç, N., Spurk, M., Veski, S. 2001. High-resolution analyses of an early Holocene climate event may imply decreased solar forcing as an important climate trigger. Geology 29, 1107-1110. 
Blackford J.J., Edwards K.J., Dugmore A.J., Cook G.T. Buckland P.C. 1992. Icelandic

volcanic ash and the mid-Holocene pollen decline in northern Scotland. The Holocene 2 (3), 260-265.

Blockley, S.P.E., Pyne-O'Donnell, S.D.F., Lowe, J.J., Matthews, I.P., Stone, A., Pollard, A.M., Turney, C.S.M., Molyneux, E.G. 2005. A new and less destructive laboratory procedure for the physical separation of distal glass tephra shards from sediments.

Quaternary Science Reviews 24, 1952-1960.

Blockley, S.P., Ramsey, C.B., Pyle, D.M. 2008. Improved age modelling and high-precision age estimates of late Quaternary tephras, for accurate palaeoclimate reconstruction. Journal of Volcanology and Geothermal Research 177, 251-262.

Blockley, S.P., Bourne, A.J., Brauer, A., Davies, S.M., Hardiman, M., Harding, P.R., Lane, C.S., MacLeod, A., Matthews, I.P., Pyne-O'Donnell, S.D., Rasmussen, S.O, Wulf, S. and Zanchetta, G. 2014. Tephrochronology and the extended intimate (integration of ice-core, marine and terrestrial records) event stratigraphy 8-128 ka b2k. Quaternary Science Reviews 106, 88-100.

Bond, G.C., Mandeville, C., Hoffmann, S. 2001. Were rhyolitic glasses in the Vedde Ash and in the North Atlantic's Ash Zone 1 produced by the same volcanic eruption?. Quaternary Science Reviews 20, 1189-1199.

Bondevik, S., Mangerud, J., Dawson, S., Dawson, A., Lohne, Ø. 2005. Evidence for three North Sea tsunamis at the Shetland Islands between 8000 and 1500 years ago. Quaternary Science Reviews 24, 1757-1775.

Bourne, A.J., Lowe, J.J., Trincardi, F., Asioli, A., Blockley, S., Wulf, S., Matthews, I.P., Piva, A., Vigliotti, L. 2010. Distal tephra record for the last ca 105,000 years from core PRAD 1-2 in the central Adriatic Sea: implications for marine tephrostratigraphy. Quaternary Science Reviews 29, 3079-3094.

Bourne, A.J., Albert, P.G., Matthews, I.P., Trincardi, F., Wulf, S., Asioli, A., Blockley, S.P.E., Keller, J., Lowe, J.J. 2015a. Tephrochronology of core PRAD 1-2 from the Adriatic Sea: insights into Italian explosive volcanism for the period 200-80 ka. Quaternary Science Reviews 116, 28-43. 
Bourne, A.J., Cook, E., Abbott, P.M., Seierstad, I.K., Steffensen, J.P., Svensson, A., Fischer, H., Schüpbach, S. Davies, S.M. 2015b. A tephra lattice for Greenland and a reconstruction of volcanic events spanning 25-45 ka b2k. Quaternary Science Reviews 118, 122-141.

Boygle, J. 1999. Variability of tephra in lake and catchment sediments, Svínavatn, Iceland.

Global and Planetary Change 21, 129-149.

Bramham-Law, C.W.F., Theuerkauf, M., Lane, C.S., Mangerud, J. 2013. New findings regarding the Saksunarvatn Ash in Germany. Journal of Quaternary Science 28, 248-257.

Brauer, A., Endres, C., Günter, C., Litt, T., Stebich, M. Negendank, J.F. 1999. High resolution sediment and vegetation responses to Younger Dryas climate change in varved lake sediments from Meerfelder Maar, Germany. Quaternary Science Reviews. 18, 321-329.

Bronk Ramsey, C. 2008. Deposition models for chronological records. Quaternary Science Reviews 27, 42-60.

Bronk Ramsey, C. 2009. Dealing with outliers and offsets in radiocarbon dating.

Radiocarbon 51, 1023-1045.

Bronk Ramsey, C., Lee, S. 2013. Recent and planned developments of the program OxCal. Radiocarbon 55, 720-730.

Bronk Ramsey, C., Albert, P.G., Blockley, S.P., Hardiman, M., Housley, R.A., Lane, C.S., Lee, S., Matthews, I.P., Smith, V.C. and Lowe, J.J. 2015. Improved age estimates for key Late Quaternary European tephra horizons in the RESET lattice. Quaternary Science Reviews 118, 18-32.

Brooks, S.J., Birks, H.J.B. 2000. Chironomid-inferred Late-glacial air temperatures at Whitrig Bog, Southeast Scotland. Journal of Quaternary Science 15, 759-764.

Brooks, S.J., Matthews, I.P., Birks, H.H., Birks, H.J.B. 2012. High resolution Lateglacial and early-Holocene summer air temperature records from Scotland inferred from chironomid assemblages. Quaternary Science Reviews 41, 67-82.

Brooks, S.J., Davies, K.L., Mather, K.A., Matthews, I.P., Lowe, J.J. 2016.

Chironomid-inferred summer temperatures for the Last Glacial-Interglacial Transition from a 
1841 lake sediment sequence in Muir Park Reservoir, west-central Scotland. Journal of

Quaternary Science 31, 214-224.

Bryant, R.H. 1974. A late-Midlandian section at Finglas River, near Waterville, Kerry. Proceedings of the Royal Irish Academy. Section B: Biological, Geological, and Chemical Science 161-178.

Bunting, M.J. 1994. Vegetation history of Orkney, Scotland: Pollen records from two small basins in west Mainland. New Phytologist 128, 771-792.

Callicott, R. 2013. Tephrochronology, ice survival of the Lateglacial Interstadial and the timing of the deglaciation of the Loch Lomond Readvance of Eilen Fada Mor, Summer Isles. Unpublished BSc Thesis, University of London.

Callicott, R. 2015. Tephrostratigraphy of a Lateglacial sequence at the Loons, Orkney. Unpublished MSc Thesis, University of London.

Candy, I., Abrook, A., Elliot, F., Lincoln, P., Matthews, I.P., Palmer, A. 2016. Oxygen Isotope evidence for high magnitude, abrupt climatic events during the Late-Glacial Interstadial in northwest Europe: Analysis of a lacustrine sequence from the site of Tirinie, Scottish Highlands. Journal of Quaternary Science 31, 607-621.

Carrivick, J.L., Russell, A.J., Rushmer, E.L., Tweed, F.S., Marren, P.M., Deeming, H. Lowe, O.J., 2009. Geomorphological evidence towards a de-glacial control on volcanism. Earth Surface Processes and Landforms 34, 1164-1178.

Cook, E., Davies, S.M., Guðmundsdóttir, E.R., Abbott, P.M., Pearce, N.J. 2018. First identification and characterization of Borrobol-type tephra in the Greenland ice cores: new deposits and improved age estimates. Journal of Quaternary Science. 33, 212-224.

Cook, E., Portnyagin, M., Ponomareva, V., Bazanova, L., Svensson, A., Garbe-Schönberg, D. 2018b. First identification of cryptotephra from the Kamchatka Peninsula in a Greenland ice core: Implications of a widespread marker deposit that links Greenland to the Pacific northwest. Quaternary Science Reviews 181, 200-206. 
Cooper, R., 1999. Lithostratigraphy and tephrochronology of sediments spanning the time interval of the Last Glacial-Interglacial Transition at Muir Park Reservoir, Scotland and Sluggan Moss, Ireland. Unpublished MSc Thesis, University of London.

Clark, C.D., Hughes, A.L., Greenwood, S.L., Jordan, C. Sejrup, H.P. 2012. Pattern and 1881 timing of retreat of the last British-Irish Ice Sheet. Quaternary Science Reviews. 44, 112-146.

1882

Clynne, M.A., Calvert, A.T., Wolfe, E.W., Evarts, R.C., Fleck, R.J., Lanphere, M.A. 2008.

The Pleistocene eruptive history of Mount St. Helens, Washington, from 300,000 to 12,800 years before present. In: Sherrod, D.R., Scott, W.E., Stauffer, P.H. (Eds.) A Volcano Rekindled: the Renewed Eruption of Mount St. Helens, 2004-2006. U.S. Geological Survey Professional Paper 1750-28, 593-627.

Dahl, S.O., Nesje, A., Lie, Ø., Fjordheim, K. Matthews, J.A. 2002. Timing, equilibrium-line altitudes and climatic implications of two early-Holocene glacier readvances during the Erdalen Event at Jostedalsbreen, western Norway. The Holocene 12, 17-25.

Darvill, C.M. 2011. The Lateglacial at Star Carr: A Sedimentological and Stable Isotopic Investigation of Palaeoenvironmental Change in Northeast England. Unpublished MSc Thesis, University of London.

Davies, L.J., Jensen, B.J.L., Froese, D.J., Wallace, K.L. 2016. Late Pleistocene and Holocene tephrostratigraphy of interior Alaska and Yukon: Key beds and chronologies over the past 30,000 years. Quaternary Science Reviews 146, 28-53.

Davies, S.M. 2003. Extending the known distributions of micro-tephra layers of Last GlacialInterglacial Transition age in Europe. Unpublished PhD Thesis, University of London.

Davies, S. M. 2015. Cryptotephras: the revolution in correlation and precision dating. Journal of Quaternary Science 30, 114-130.

Davies S.M., Turney C.S.M., Lowe JJ. 2001. Identification and significance of a visible, basalt-rich Vedde Ash layer in a Late-glacial sequence on the Isle of Skye, Inner Hebrides, Scotland. Journal of Quaternary Science 16, 99-104.

Davies, S.M., Branch, N.P., Lowe, J.J., Turney, C.S. 2002. Towards a European 1912 tephrochronological framework for Termination 1 and the Early Holocene. Philosophical 
Transactions of the Royal Society of London A: Mathematical, Physical and Engineering 1914 Sciences $360,767-802$.

1915

1916

1917

1918

1919

1920

1921

1922

1923

1924

1925

1926

1927

1928

1929

1930

1931

1932

1933

1934

1935

1936

1937

1938

1939

1940

1941

1942

1943

1944

1945

1946

1947

1948

1949

Davies S.M., Wastegård, S. Wohlfarth, B. 2003. Extending the limits of the Borrobol Tephra to Scandinavia and detection of new early Holocene tephras. Quaternary Research 59, 345352.

Davies, S.M., Wohlfarth, B., Wastegård, S., Andersson, M., Blockley, S., Possnert, G. 2004. Were there two Borrobol Tephras during the early Lateglacial period: implications for tephrochronology?. Quaternary Science Reviews 23, 581-589.

Davies, S.M., Elmquist, M., Bergman, J., Wohlfarth, B., Hammarlund, D. 2007. Cryptotephra sedimentation processes within two lacustrine sequences from west central Sweden. The Holocene 17, 319-330.

Davies, S.M., Larsen, G., Wastegård, S., Turney, C.S., Hall, V.A., Coyle, L. Thordarson, T. 2010. Widespread dispersal of Icelandic tephra: how does the Eyjafjöll eruption of 2010 compare to past Icelandic events?. Journal of Quaternary Science 25, 605-611.

Davies, S.M., Abbott, P.M., Pearce, N.J., Wastegård, S., Blockley, S.P. 2012. Integrating the INTIMATE records using tephrochronology: rising to the challenge. Quaternary Science Reviews 36, 11-27.

Davies, S.M., Abbott, P.M., Meara, R.H., Pearce, N.J., Austin, W.E., Chapman, M.R., Svensson, A., Bigler, M., Rasmussen, T.L., Rasmussen, S.O., Farmer, E.J. 2014. A North Atlantic tephrostratigraphical framework for 130-60 ka b2k: new tephra discoveries, marinebased correlations, and future challenges. Quaternary Science Reviews, 106, 101-121.

Dugmore, A.1989. Icelandic volcanic ash in Scotland. The Scottish Geographical Magazine $105,168-172$.

Dugmore, A.J., Newton, A.J. 1992. Thin tephra layers in peat revealed by X-radiography. Journal of Archaeological Science 19, 163-170.

Eden, D.N., Froggatt, P.C., McIntosh, P.D. 1992. The distribution and composition of volcanic glass in late Quaternary loess deposits of southern South Island, New Zealand, and some possible correlations. New Zealand Journal of Geology and Geophysics 35, 69-79. 
Gehrels, M.J., Newnham, R.M., Lowe, D.J., Wynne, S., Hazell, Z.J., Caseldine, C. 2008. Towards rapid assay of cryptotephra in peat cores: review and evaluation of various methods. Quaternary International 178, 68-84.

Griggs, A.J., Davies, S.M., Abbott, P.M., Coleman, M., Palmer, A.P., Rasmussen, T.L., Johnston, R. 2015. Visualizing tephra deposits and sedimentary processes in the marine environment: The potential of X-ray microtomography. Geochemistry, Geophysics, Geosystems 16, 4329-4343.

Grönvold, K., Óskarsson, N., Johnsen, S.J., Clausen, H.B., Hammer, C.U., Bond, G. Bard, E. 1995. Ash layers from Iceland in the Greenland GRIP ice core correlated with oceanic and land sediments. Earth and Planetary Science Letters 135, 149-155.

Gudmundsdóttir, E.R., Eiríksson, J., Larsen, G. 2011. Identification and definition of primary and reworked tephra in Late Glacial and Holocene marine shelf sediments off North Iceland. Journal of Quaternary Science 26, 589-602.

Gudmundsdóttir, E.R., Larsen, G., Eiríksson, J. 2012: Tephra stratigraphy on the North Icelandic shelf: extending tephrochronology into marine sediments off North Iceland. Boreas $41,719-734$.

Gudmundsdóttir, E.R., Larsen, G., Björck, S., Ingólfsson, Ó., Striberger, J. 2016. A new highresolution Holocene tephra stratigraphy in eastern Iceland: Improving the Icelandic and North Atlantic tephrochronology. Quaternary Science Reviews 150, 234-249.

Hardiman, M., 2007. The Lateglacial sediment record in Loch Etteridge, Grampian Highlands, Scotland: tephrostratigraphy and regional tephrocorrelation. Unpublished BSc Thesis, University of London.

Harning, D.J., Thordarson, T., Geirsdóttir, Á., Zalzal, K., Miller, G.H. 2018. Provenance, stratigraphy and chronology of Holocene tephra from Vestfirðir, Iceland. Quaternary Geochronology 46, 59-76.

Hayward, C. 2012. High spatial resolution electron probe microanalysis of tephras and melt inclusions without beam-induced chemical modification. The Holocene, 22, 119-125. 
Housley, R.A., Lane, C.S., Cullen, V.L., Weber, M.J., Riede, F., Gamble, C.S., Brock, F.

1988

1989

1990

1991

1992

1993

1994

1995

1996

1997

1998

1999

2000

2001

2002

2003

2004

2005

2006

2007

2008

2009

2017

2021 2012. Icelandic volcanic ash from the Late-glacial open-air archaeological site of Ahrenshöft LA 58 D, North Germany. Journal of Archaeological Science 39, 708-716.

Housley, R.A., MacLeod, A., Nalepka, D., Jurochnik, A., Masojć, M., Davies, L., Lincoln, P.C., Ramsey, C.B., Gamble, C.S. Lowe, J.J. 2013. Tephrostratigraphy of a Lateglacial lake sediment sequence at Węgliny, southwest Poland. Quaternary Science Reviews 77, 4-18.

Housley, R.A Lincoln, P.C., MacLeod, A. 2018. Tephrochronology of borehole 50a in the Priest's Well basin. In Reindeer hunters at Howburn Farm, South Lanarkshire, A Late Hamburgian settlement in southern Scotland - its lithic artefacts and natural environment. ed. by Ballin, T,B., Saville, A., Tipping, R., Ward, T., Housely, R., Verrill, L., Bradley, M., Wilson, C., Lincoln, P., MacLeod, A. Oxford: Archaeolpress Archaeology: 90-96. ISBN 9781784919016.

Hughes, A.L., Gyllencreutz, R., Lohne, O.S., Mangerud, J., Svendsen, J.I. 2016. The last Eurasian ice sheets - a chronological database and time-slice reconstruction, DATED-1. Boreas 45, 1-45.

Huntley, B. 1993. Rapid early-Holocene migration and high abundance of hazel (Corylus avellana L.): alternative hypotheses. In Chambers, F.M. (ed.), Climate Change and Human Impact on the Landscape, Springer, Dordrecht, 205-215.

Jennings, A.E., Grönvold, K., Hilberman, R., Smith, M., Hald, M. 2002. High-resolution study of Icelandic tephras in the Kangerlussuaq Trough, southeast Greenland, during the last deglaciation. Journal of Quaternary Science 17, 747-757.

Jennings, A., Thordarson, T., Zalzal, K., Stoner, J., Hayward, C., Geirsdóttir, Á., Miller, G. 2014. Holocene tephra from Iceland and Alaska in SE Greenland shelf sediments.

Geological Society, London, Special Publications 398, 157-193.

2018 Jensen, B.J., Pyne-O’Donnell, S., Plunkett, G., Froese, D.G., Hughes, P.D., Sigl, M., 2019 McConnell, J.R., Amesbury, M.J., Blackwell, P.G., van den Bogaard, C. Buck, C.E. 2014.

2020 Transatlantic distribution of the Alaskan white river ash. Geology 42, 875-878.

Jöhansen J. 1977. Outwash of terrestric soils into Lake Saksunarvatn, Faroe Islands.

Danmarks Geologiske Undersøgelse Årbog 31-37. 

annesdóttir, G.E., Thordarson, T., Geirsdóttir, Á., Larsen, G. 2005. The widespread 10 ka Saksunarvatn tephra: a product of three large basaltic phreatoplinian eruptions. In: Geophysical Research Abstracts 7 (05991), 01607-0796.

Jones, G., Davies, S.M., Farr, G.J., Bevan, J. 2017. Identification of the Askja-S Tephra in a rare turlough record from Pant-y-Llyn, south Wales. Proceedings of the Geologists' Association 128 (4), 523-530.

Jones, G., Lane, C.S., Brauer, A., Davies, S.M., Bruijn, R., Engels, S., Haliuc, A., Hoek, W.Z., Merkt, J., Sachse, D. Turner, F. 2018. The Lateglacial to early Holocene tephrochronological record from Lake Hämelsee, Germany: a key site within the European tephra framework. Boreas 47, 28-40.

Jørgensen, K.A. 1980. The Thorsmörk ignimbrite: an unusual comenditic pyroclastic flow in southern Iceland. Journal of Volcanology and Geothermal Research 8, 7-22.

Kearney, R., Albert, P.G., Staff, R.A., Pál, I., Veres, D., Magyari, E., Ramsey, C.B. 2018. Ultra-distal fine ash occurrences of the Icelandic Askja-S Plinian eruption deposits in Southern Carpathian lakes: New age constraints on a continental scale tephrostratigraphic marker. Quaternary Science Reviews 188, 174-182.

Kelly, T.J., Hardiman, M., Lovelady, M., Lowe, J.J., Matthews, I.P., Blockley, S.P. 2017. Scottish early Holocene vegetation dynamics based on pollen and tephra records from Inverlair and Loch Etteridge, Inverness-shire. Proceedings of the Geologists' Association $128,125-135$.

Koren, J.H., Svendsen, J.I., Mangerud, J. Furnes, H. 2008. The Dimna Ash - a 12.8 14C kaold volcanic ash in Western Norway. Quaternary Science Reviews 27, 85-94.

Kristjánsdóttir, G.B., Stoner, J.S., Jennings, A.E., Andrews, J.T., Grönvold, K 2007. Geochemistry of Holocene cryptotephras from the North Iceland Shelf (MD99-2269): intercalibration with radiocarbon and palaeomagnetic chronostratigraphies. The Holocene $17,155-176$.

Kuehn, S.C., Froese, D.G., Carrara, P.E., Foit, F.F., Pearce, N.J., Rotheisler, P. 2009. Major-and trace-element characterization, expanded distribution, and a new chronology for 
the latest Pleistocene Glacier Peak tephras in western North America. Quaternary Research. 71, 201-216.

Kylander, M.E., Lind, E.M., Wastegård, S., Löwemark, L. 2011. Recommendations for using XRF core scanning as a tool in tephrochronology. The Holocene 22, 371-375.

Lacasse, C., Sugurdsson, H., Jóhannesson, H., Paterne, M., Carey, S. 1995. Source of Ash Zone 1 in the North Atlantic. Bulletin of Volcanology 57, 18-32.

Lane, C.S., Andrič, M., Cullen, V.L., Blockley, S.P. 2011a. The occurrence of distal Icelandic and Italian tephra in the Lateglacial of Lake Bled, Slovenia. Quaternary Science Reviews 30,1013-1018.

Lane, C. S., Blockley, S. P. E., Bronk Ramsey, C., Lotter, A. F. 2011b. Tephrochronology and absolute centennial scale synchronisation of European and Greenland records for the last glacial to interglacial transition: A case study of Soppensee and NGRIP. Quaternary International. 246,145-156.

Lane, C.S., Blockley, S.P.E., Mangerud, J., Smith, V.C., Lohne, Ø., Tomlinson, E.L., Matthews, I.P., Lotter, A.F. 2012a. Was the 12.1ka Icelandic Vedde Ash one of a kind?. Quaternary Science Reviews 33, 87-99.

Lane, C.S., De Klerk, P. and Cullen, V.L. 2012b: A tephrochronology for the Lateglacial palynological record of the Endinger Bruch (Vorpommern, north-east Germany). Journal of Quaternary Science. 27, 141-149.

Lane, C.S., Brauer, A., Blockley, S.P. and Dulski, P. 2013. Volcanic ash reveals timetransgressive abrupt climate change during the Younger Dryas. Geology 41, 1251-1254.

Lane, C.S., Lowe, D.J., Blockley, S.P.E., Suzuki, T. Smith, V.C. 2017. Advancing tephrochronology as a global dating tool: Applications in volcanology, archaeology, and palaeoclimatic research. Quaternary Geochronology 40, 1-7.

Lane, C.S., Martin-Jones, C.M., Johnson, T.C. 2018. A cryptotephra record from the Lake Victoria sediment core record of Holocene palaeoenvironmental change. The Holocene, p.0959683618798163. 
Lang, B., Brooks, S.J., Bedford, A., Jones, R.T., Birks, H.J.B., Marshall, J.D. 2010. Regional consistency in Lateglacial chironomid-inferred temperatures from five sites in north-west

England. Quaternary Science Reviews 29, 1528-1538.

2101

Larsen J.J. 2013. Lateglacial and Holocene tephrostratigraphy in Denmark Volcanic ash in a palaeoenvironmental context. Unpublished PhD thesis, University of Copenhagen

Larsen, J.J., Noe-Nygaard, N., 2014. Lateglacial and early Holocene tephrostratigraphy and sedimentology of the Store Slotseng basin, SW Denmark: a multi-proxy study. Boreas 43, 349-361.

Lilja, C., Lind, E.M., Morén, B., Wastegård, S. 2013. A Lateglacial-early Holocene tephrochronology for SW Sweden. Boreas 42, 544-554.

Lincoln, P.C. 2011. Tephrostratigraphic and Taphonomic study from Pulpit Hill, Western Scotland. Unpublished MSc Thesis, University of London.

Lind, E.M., Wastegård, S. 2011. Tephra horizons contemporary with short early Holocene climate fluctuations: new results from the Faroe Islands. Quaternary International 246, 157167.

Lind, E.M., Wastegård, S., Larsen, J.J. 2013. A Late Younger Dryas-Early Holocene tephrostratigraphy for Fosen, Central Norway. Journal of Quaternary Science 28, 803-811.

Lind, E.M., Lilja, C., Wastegård, S., Pearce, N.J. 2016. Revisiting the Borrobol tephra. Boreas 45, 629-643.

Lohne Ø.S., Mangerud J., Birks H.H. 2014. IntCal13 calibrated ages of the Vedde and Saksunarvatn ashes and the Younger Dryas boundaries from Kråkenes, western Norway. Journal of Quaternary Science 29, 506-507.

Lowe, D.J. 2008. Globalization of tephrochronology: new views from Australasia. Progress in Physical Geography 32, 311-335.

Lowe, D.J. 2011. Tephrochronology and its application: a review. Quaternary Geochronology $6(2), 107-153$. 
Lowe, D.J., Hunt, J.B. 2001. A summary of terminology used in tephra-related studies. Les

Lowe, D.J., Shane, P.A., Alloway, B.V. Newnham, R.M. 2008. Fingerprints and age models for widespread New Zealand tephra marker beds erupted since 30,000 years ago: a framework for NZ-INTIMATE. Quaternary Science Reviews 27, 95-126.

Lowe, D.J., Blaauw, M., Hogg, A.G., Newnham, R.M. 2013. Ages of 24 widespread tephras erupted since 30,000 years ago in New Zealand, with re-evaluation of the timing and palaeoclimatic implications of the Lateglacial cool episode recorded at Kaipo bog.

Quaternary Science Reviews 74, 170-194.

Lowe, D.J., Pearce, N.J.G., Jorgensen, M.A., Kuehn, S.C., Tryon, C.A., Hayward, C.L. 2017. Correlating tephras and cryptotephras using glass compositional analyses and numerical and statistical methods: Review and evaluation. Quaternary Science Reviews $175,1-44$

Lowe, J.J. 2001. Abrupt climatic changes in Europe during the last glacial-interglacial transition: the potential for testing hypotheses on the synchroneity of climatic events using tephrochronology. Global and Planetary Change 30, 73-84.

Lowe, J.J., Lowe, S. 1989. Interpretation of the pollen stratigraphy of Late Devensian lateglacial and early Flandrian sediments at Liyn Gwernan, near Cader Idris. North Wales. New Phytologist 113, 391-408.

Lowe, J.J., Turney, C.S.M. 1997. Vedde ash layer discovered in a small lake basin on the Scottish mainland' Journal of the Geological Society 154, 605-612.

Lowe, J.J., Walker, M.J.C. 1986. Lateglacial and early Flandrian environmental history of the Isle of Mull, Inner Hebrides, Scotland. Transactions of the Royal Society of Edinburgh Earth Sciences, 77, 1-30.

Lowe, J.J. Roberts, S.J. 2003. Muir Park Reservoir. In: Evans, D.J.A (Ed.), The Quaternary of the Western Highland Boundary: Field Guide. Quaternary Research Association, London 117-124. 
Lowe, J.J., Birks, H.H., Brooks, S.J., Coope, G.R., Harkness, D.D., Mayle, F.E., Sheldrick, C., Turney, C.S.M., Walker, M.J.C. 1999. The chronology of palaeoenvironmental changes during the Last Glacial-Holocene transition: towards an event stratigraphy for the British Isles. Journal of the Geological Society 156, 397-410.

Lowe, J., Albert, P., Hardiman, M., MacLeod, A., Blockley, S. Pyne-O’Donnell, S. 2008. Tephrostratigraphical investigations of the basal sediment sequence at Loch Etteridge. In: The Quaternary of Glen Roy and Vicinity Field Guide. ed. by Palmer, A.P., Lowe, J.J., Rose, J. Quaternary Research Association, 60-65.

\section{Lowe, J.J., Ramsey, C.B., Housley, R.A., Lane, C.S., Tomlinson, E.L., RESET Team.,} RESET Associates. 2015. The RESET project: constructing a European tephra lattice for refined synchronisation of environmental and archaeological events during the last c. $100 \mathrm{ka}$. Quaternary Science Reviews 118, 1-17.

Lowe, J., Pyne-O'Donnell, S.D.F., Timms, R. 2016. Tephra layers on Skye dating to the Lateglacial-Early Holocene interval and their wider context. In: Ballantyne, C., Lowe, J. (Eds.), The Quaternary of Skye: Field Guide. Quaternary Research Association. Quaternary Research Association, London, 157-183.

Lowe, J.J., Palmer, A.P., Carter-Champion, A., MacLeod, A.M., Ramirez-Rojas, I., Timms, R.G.O. 2017. Stratigraphy of a Lateglacial lake basin sediment sequence at Turret Bank, Upper Glen Roy, Lochaber: implications for the age of the Turret Fan. Proceedings of the Geologists' Association 128, 110-124.

Lowe, J.J., Matthews, I.P., Mayfield, R., Lincoln., P.C., Palmer, A., Timms, R.G.O. in prep. On the timing of the last glaciers to occupy the SW Scottish Highlands and the impropriety of the universal use of the term 'Younger Dryas'.

MacDonald, R., McGarvie, D. W., Pinkerton, H., Smith, R. L., Palacz, A. 1990. Petrogenetic evolution of the Torfajökull Volcanic Complex, Iceland I. Relationship between the magma types. Journal of Petrology 31, 429-459.

Mackay, H., Hughes, P.D.M., Jensen, B.J.L., Langdon, P.G., Pyne-O’Donnell, S.D.F., Plunkett, G., Froese, D.G., Coulter, S., Gardner, J.E. 2016. Mid to late Holocene cryptotephra framework from eastern North America. Quaternary Science Reviews 132, 101113. 
Mackie, E.A., Davies, S.M., Turney, C.S., Dobbyn, K., Lowe, J.J. Hill, P.G. 2002. The use of magnetic separation techniques to detect basaltic microtephra in last glacial-interglacial transition (LGIT; 15-10 ka cal. BP) sediment sequences in Scotland. Scottish Journal of Geology 38, 21-30.

Maclennan, J., Jull, M., McKenzie, D., Slater, L., Grönvold, K. 2002. The link between volcanism and deglaciation in Iceland. Geochemistry, Geophysics, Geosystems 3, 1-25.

MacLeod, A. 2008. Tephrostratigraphy of the Loch Laggan East lake sequence. in The Quaternary of Glen Roy and Vicinity Field Guide. ed by Palmer AP, Lowe JJ, Rose J. Quaternary Research Association, London, 83-91.

MacLeod, A., Matthews, I.P., Lowe, J.J., Palmer, A.P., Albert, P.G. 2015. A second tephra isochron for the Younger Dryas period in northern Europe: The Abernethy Tephra.

Quaternary Geochronology 28, 1-11.

Mangerud, J., Lie, S. E., Furnes, H., Kristiansen, I. L., Lømo, L. 1984. A Younger Dryas ash bed in western Norway, and its possible correlations with tephra in cores from the Norwegian Sea and the North Atlantic. Quaternary Research 21, 85-104.

Mangerud, J., Furnes, H., Jóhansen, J. 1986. A 9000-year-old ash bed on the Faroe Islands. Quaternary Research 26, 262-265.

Marshall, J.D., Jones, R.T., Crowley, S.F., Oldfield, F., Nash, S. Bedford, A. 2002. A high resolution late-glacial isotopic record from Hawes Water, northwest England Climatic oscillations: Calibration and comparison of palaeotemperature proxies. Palaeogeography, Palaeoclimatology, Palaeoecology 185, 25-40.

Matthews, I.P. 2008. The potential of tephrostratigraphy in the investigation of wetland archaeological records. Unpublished PhD thesis, University of London.

Matthews, I.P., Birks, H.H., Bourne, A.J., Brooks, S.J., Lowe, J.J., MacLeod, A. Pyne-O'Donnell, S.D.F. 2011. New age estimates and climatostratigraphic correlations for the Borrobol and Penifiler Tephras: evidence from Abernethy Forest, Scotland. Journal of Quaternary Science 26, 247-252. 
Matthews, I.P., Trincardi, F., Lowe, J.J., Bourne, A.J., MacLeod, A., Abbott, P.M., Anderson, N., Asioli, A., Blockley, S.P.E., Lane, C.S., Oh, Y.A., Satow, C.S., Staff, R.A., Wulf, S. 2015.

Developing a robust tephrochronological framework for Late Quaternary marine records in the Southern Adriatic Sea: new data from core station SA03-11. Quaternary Science Reviews 118, 84-104.

McGarvie, D.W., Macdonald, R., Pinkerton, H. Smith, R.L. 1990. Petrogenetic evolution of the Torfajökull Volcanic Complex, Iceland II. The role of magma mixing. Journal of Petrology $31,461-481$

McLean, D., Albert, P.G., Nakagawa, T., Suzuki, T., Staff, R.A., Yamada, K., Kitaba, I., Haraguchi, T., Kitagawa, J., Smith, V. 2018. Integrating the Holocene tephrostratigraphy for East Asia using a high-resolution cryptotephra study from Lake Suigetsu (SG14 core), central Japan. Quaternary Science Reviews 183, 36-58.

Mithen, S., Wicks, K., Pirie, A., Riede, F., Lane, C., Banerjea, R., Cullen, V., Gittins, M. Pankhurst, N. 2015. A Lateglacial archaeological site in the far north-west of Europe at Rubha Port an t-Seilich, Isle of Islay, western Scotland: Ahrensburgian-style artefacts, absolute dating and geoarchaeology. Journal of Quaternary Science 30, 396-416.

Moles, J.D., McGarvie, D., Stevenson, J.A., Sherlock, S.C. 2018. Geology of Tindfjallajökull volcano, Iceland. Journal of Maps 14, 22-31.

Moles, J.D., McGarvie, D., Stevenson, J.A., Sherlock, S.C., Abbott, P.M., Jenner, F.E., Halton, A.M. (in review) Widespread tephra dispersal and ignimbrite emplacement from a subglacial volcano: the rhyolitic eruption of Torfajökull, Iceland, $55 \mathrm{ka}$.

Moriwaki, H., Nakamura, N., Nagasako, T., Lowe, D.J., Sangawa, T. 2016. The role of tephras in developing a high-precision chronostratigraphy for palaeoenvironmental reconstruction and archaeology in southern Kyushu, Japan, since 30,000 cal. BP: an integration. Quaternary International 397, 79-92.

Mortensen, A.K., Bigler, M., Grönvold, K., Steffensen, J.P., Johnsen, S.J. 2005. Volcanic ash layers from the Last Glacial Termination in the NGRIP ice core. Journal of Quaternary Science 20, 209-219. 
Muschitiello, F. and Wohlfarth, B. 2015. Time-transgressive environmental shifts across Northern Europe at the onset of the Younger Dryas. Quaternary Science Reviews 109, 4956.

Narcisi, B., Petit, J.R., Delmonte, B. 2010. Extended East Antarctic ice-core tephrostratigraphy. Quaternary Science Reviews 29, 21-27.

Neave, D.A., Maclennan, J., Thordarson, T., Hartley, M.E. 2015. The evolution and storage of primitive melts in the Eastern Volcanic Zone of Iceland: the $10 \mathrm{ka}$ Grímsvötn tephra series (i.e. the Saksunarvatn ash). Contributions to Mineralogy and Petrology 170, 1-23.

Newnham, R.M. Lowe, D.J. 1999. Testing the synchroneity of pollen signals using tephrostratigraphy. Global and Planetary Change 21, 113-128.

Noe-Nygaard A. 1951. Sub-fossil Hekla pumice from Denmark. Medd fra Dansk Geol Forening 12, 35-46.

Normand, S., Ricklefs, R.E., Skov, F., Bladt, J., Tackenberg, O, Svenning, J.C. 2011. Postglacial migration supplements climate in determining plant species ranges in Europe. Proceedings of the Royal Society, series B, doi:10.1098/rspb.2010.2769.

Ott, F., Wulf, S., Serb, J., Słowiński, M., Obremska, M., Tjallingii, R., Błaszkiewicz, M. Brauer, A. 2016. Constraining the time span between the Early Holocene Hässeldalen and Askja-S Tephras through varve counting in the Lake Czechowskie sediment record, Poland. Journal of Quaternary Science 31, 103-113.

Palmer, A.P., Lowe, J.J. 2017. Dynamic landscape changes in Glen Roy and vicinity, west Highland Scotland, during the Last Termination: a synthesis. Proceedings of the Geologists' Association 128, 2-25.

Palmer, A.P., Rose, J., Lowe, J.J., MacLeod, A. 2010. Annually-resolved events of Younger Dryas glaciation in Lochaber (Glen Roy and Glen Spean), Western Scottish Highlands. Journal of Quaternary Science 25, 581-596.

Peacock, J.D. Rose, J. 2017. Was the Younger Dryas (Loch Lomond Stadial) icefield on Rannoch Moor, western Scotland, deglaciated as early as c. 12.5 cal ka BP?. Proceedings of the Geologists' Association 128, 173-179. 
Pearce, N.J., Abbott, P.M., Martin-Jones, C. 2014. Microbeam methods for the analysis of glass in fine-grained tephra deposits: a SMART perspective on current and future trends. Geological Society, London, Special Publications, 398, SP398-1.

Persson, C. 1966. Försök till tefrokronologisk datering av några svenska torvmossar. Geologiska Föreningens i Stockholm Förhandlingar 88, 361-395.

Phillips, W.M., Hall, A.M., Ballantyne, C.K., Binnie, S., Kubik, P.W., Freeman, S. 2008.

Extent of the last ice sheet in northern Scotland tested with cosmogenic ${ }^{10} \mathrm{Be}$ exposure ages. Journal of Quaternary Science 23, 101-107.

Pilcher J.R., Hall V.A. 1992. Towards a tephrochronology for the Holocene of the north of Ireland. The Holocene 2, 255-259.

Pilcher, J., Bradley, R.S., Francus, P., Anderson, L. 2005. A Holocene tephra record from the Lofoten Islands, Arctic Norway. Boreas 34, 136-156.

Plunkett, G., Pilcher, J.R. 2018. Defining the potential source region of volcanic ash in northwest Europe during the Mid-to Late Holocene. Earth-Science Reviews 179, 20-37.

Pollard, A.M., Blockley, S.P.E., Ward, K.R. 2003. Chemical alteration of tephra in the depositional environment: theoretical stability modelling. Journal of Quaternary Science 18, 385-394.

Ponomareva, V., Portnyagin, M., Pendea, I.F., Zelenin, E., Bourgeois, J., Pinegina, T., Kozhurin, A. 2017. A full holocene tephrochronology for the Kamchatsky Peninsula region: Applications from Kamchatka to North America. Quaternary Science Reviews 168, 101-122.

Porter, S.C. 1978. Glacier Peak tephra in the North Cascade Range, Washington:

Stratigraphy, distribution, and relationship to late-glacial events. Quaternary Research. 10, 30-41

Pyne-O'Donnell, S.D.F. 2005. The factors affecting the distribution and preservation of microtephra particles in Lateglacial and early Holocene lake sediments. Unpublished PhD thesis, University of London. 
Pyne-O'Donnell, S.D.F. 2007. Three new distal tephras in sediments spanning the Last

Glacial-Interglacial Transition in Scotland. Journal of Quaternary Science 22, 559-570.

Pyne-O'Donnell, S. 2011. The taphonomy of Last Glacial-Interglacial Transition (LGIT) distal volcanic ash in small Scottish lakes. Boreas 40, 131-145.

Pyne-O'Donnell, S.D.F., Blockley, S.P.E., Turney, C.S.M. and Lowe, J.J. 2008. Distal volcanic ash layers in the Lateglacial Interstadial (GI-1): problems of stratigraphic discrimination. Quaternary Science Reviews 27, 72-84.

Pyne-O'Donnell, S.D., Cwynar, L.C., Jensen, B.J., Vincent, J.H., Kuehn, S.C., Spear, R. Froese, D.G. 2016. West Coast volcanic ashes provide a new continental-scale Lateglacial isochron. Quaternary Science Reviews 142, 16-25.

Pyne-O'Donnell, S., Jensen, B. 2018. The Glacier Peak ash in Scotland. INTAV International Field Conference on Tephrochronology - Crossing New Frontiers, O 1.4.

Rach, O., Brauer, A., Wilkes, H., Sachse, D. 2014. Delayed hydrological response to Greenland cooling at the onset of the Younger Dryas in western Europe. Nature Geoscience 7, 109-112.

Ranner, P.H., Allen, J.R.M., Huntley, B. 2005. A new early Holocene cryptotephra from northwest Scotland. Journal of Quaternary Science 20, 201-208.

Rasmussen, S.O., Andersen, K.K., Svensson, A.M., Steffensen, J.P., Vinther, B.M., Clausen, H.B., Siggaard-Andersen, M.L., Johnsen, S.J., Larsen, L.B., Dahl-Jensen, D., Bigler, M., Röthlisberger, R., Fischer, H., Goto-Azuma, K., Hansson, M.E., Ruth, U. 2006. A new Greenland ice core chronology for the last glacial termination. Journal of Geophysical Research D: Atmospheres 111, D06102.

Reimer, P.J., Bard, E., Bayliss, A., Beck, J.W., Blackwell, P.G., Ramsey, C.B., Buck, C.E., Cheng, H., Edwards, R.L., Friedrich, M., Grootes, P.M. 2013. IntCal13 and Marine13 radiocarbon age calibration curves 0-50,000 years cal BP. Radiocarbon 55, 1869-1887. 2388

Roberts, S.J. 1997. The spatial and geochemical characteristics of Lateglacial tephra deposits of Scotland and Northern England. Unpublished MSc Thesis, University of London. 
Roberts, S.J., Turney, C.C.M., Lowe, J. 1998. Icelandic Tephra in Late-glacial Sediments of Scotland (14 - 9,000 14C BP). Fróđskaparrit 46, 335-339.

Rose, J. 1985. The Dimlington Stadial/Dimlington Chronozone: a proposal for naming the main glacial episode of the Late Devensian in Britain. Boreas 14, 225-230.

Ruddiman, W.F., Mclntyre, A. 1981. The North Atlantic Ocean during the last deglaciation. Palaeogeography, Palaeoclimatology, Palaeoecology 35, 145-214.

Sigmundsson, F., Pinel, V., Lund, B., Albino, F., Pagli, C., Geirsson, H., Sturkell, E. 2010. Climate effects on volcanism: Influence on magmatic systems of loading and unloading from ice mass variations, with examples from Iceland. Philosophical Transactions of the Royal Society A: Mathematical, Physical and Engineering Sciences 368, 2519-2534.

Sigvaldason, G.E. 2002. Volcanic and tectonic processes coinciding with glaciation and crustal rebound: an early Holocene rhyolitic eruption in the Dyngjufjöll volcanic centre and the formation of the Askja caldera, north Iceland. Bulletin of Volcanology 64, 192-205.

Stevenson, J.A., Loughlin, S., Rae, C., Thordarson, T., Milodowski, A.E., Gilbert, J.S., Harangi, S., Lukács, R., Højgaard, B., Árting, U., Pyne-O'Donnell, S., MacLeod, A., Whitney, B., Cassidy, M. 2012. Distal deposition of tephra from the Eyjafjallajökull 2010 summit eruption. Journal of Geophysical Research: Solid Earth 117, (B9).

Stevenson, J.A., Loughlin, S.C., Font, A., Fuller, G.W., MacLeod, A., Oliver, I.W., Jackson, B., Horwell, C.J., Thordarson, T., Dawson, I. 2013. UK monitoring and deposition of tephra from the May 2011 eruption of Grímsvötn, Iceland. Journal of Applied Volcanology 2, 1-17.

Swindles, G.T., Lawson, I.T., Savov, I.P., Connor, C.B., Plunkett, G. 2011. A 7000 yr perspective on volcanic ash clouds affecting northern Europe. Geology 39, 887-890.

Thordarson T. 2014. The widespread $\sim 10$ ka Saksunarvatn tephra is not a product single eruption. American Geophysical Union, Fall Meeting 2014, V24B-04.

Thornalley, D.J., McCave, I.N., Elderfield, H. 2011. Tephra in deglacial ocean sediments south of Iceland: Stratigraphy, geochemistry and oceanic reservoir ages. Journal of Quaternary Science 26, 190-198. 
Timms, R.G.O. 2016. Developing a refined tephrostratigraphy for Scotland, and constraining abrupt climatic oscillations of the Last Glacial-Interglacial Transition (ca 16-8 ka BP) using high resolution tephrochronologies. Unpublished PhD thesis, University of London.

Timms, R.G.O., Matthews, I.P., Palmer, A.P., Candy, I., Abel, L. 2017. A high-resolution tephrostratigraphy from Quoyloo Meadow, Orkney, Scotland: implications for the tephrostratigraphy of NW Europe during the Last Glacial-Interglacial Transition. Quaternary Geochronology 40, 67-81.

Timms, R.G.O., Matthews, I.P., Palmer, A.P., Candy, I. 2018: Toward a tephrostratigraphic framework for the British Isles: a Last Glacial to Interglacial Transition (LGIT c. 16-8 ka) case study from Crudale Meadow, Orkney. Quaternary Geochronology 46, 28-44.

Tipping, R. M. 1987. The prospects for establishing synchroneity in the early postglacial pollen peak of Juniperus in the British Isles. Boreas 16, 155-163.

Tomlinson, E.L., Thordarson, T., Müller, W., Thirlwall, M., Menzies, M.A. 2010. Microanalysis of tephra by LA-ICP-MS - strategies, advantages and limitations assessed using the Thorsmörk Ignimbrite (Southern Iceland). Chemical Geology 279, 73-89.

Tomlinson, E.L., Thordarson, T., Lane, C.S., Smith, V.C., Manning, C.J., Müller, W. Menzies, M.A. 2012. Petrogenesis of the Sólheimar ignimbrite (Katla, Iceland): Implications for tephrostratigraphy. Geochimica et Cosmochimica Acta 86, 318-337.

Tomlinson, E.L., Smith, V.C., Albert, P.G., Aydar, E., Civetta, L., Cioni, R., Cubukcu, E.,Gertisser, R., Isaia, R., Menzies, M.A., Orsi, G., Rosi, M., Zanchetta, G. 2015. The major and trace element glass compositions of the productive Mediterranean volcanic sources: tools for correlating distal tephra layers in and around Europe. Quaternary Science Reviews $118,48-66$.

Turney, C.S.M. 1998a. Extraction of rhyolitic component of Vedde microtephra from minerogenic lake sediments. Journal of Paleolimnology 19, 199-206.

Turney, C.S.M. 1998b. Isotope stratigraphy and tephrochronology of the Last GlacialInterglacial Transition (14-9 ka ${ }^{14} \mathrm{C} \mathrm{BP}$ ) in the British Isles. Unpublished PhD thesis, University of London. 
Turney, C.S., Harkness, D.D., Lowe, J.J. 1997. Rapid Communication: The use of microtephra horizons to correlate Late-glacial lake sediment successions in Scotland. Journal of Quaternary Science 12 (6), 525-531.

Turney C.S.M., Van Den Burg, K., Wastegård, S., Davies, S.M., Whitehouse, N.J., Pilcher, 2471 J.R., Callaghan, C. 2006. North European last glacial-interglacial transition (LGIT; 15-9 ka) tephrochronology: extended limits and new events. Journal of Quaternary Science 21, 3352473 345.

2474

Pórarinsson, S. 1944: Tefrokronologiska studier pa Island. Geografiska Annaler 26, 1-217.

Valentine, H. 2015. Constraining the timing of deglaciation on Priest Island, Summer Isles using tephrostratigraphy, Unpublished MSc thesis, University of London.

van Asch, N., Lutz, A.F., Duijkers, M.C., Heiri, O., Brooks, S.J., Hoek, W.Z. 2012. Rapid climate change during the Weichselian Lateglacial in Ireland: Chironomid-inferred summer temperatures from Fiddaun, Co. Galway. Palaeogeography, Palaeoclimatology, Palaeoecology 315, 1-11.

Van der Bilt, W.G.M., Lane, C.S., Bakke, J. 2017. Ultra-distal Kamchatkan ash on Arctic Svalbard: Towards hemispheric cryptotephra correlation. Quaternary Science Reviews 164, 230-235.

Van Vliet-Lanoë, B., Guðmundsson, Å., Guillou, H., Duncan, R.A., Genty, D., Ghaleb, B., Gouy, S., Récourt, P. Scaillet, S. 2007. Limited glaciation and very early deglaciation in central Iceland: implications for climate change. Comptes Rendus Geoscience 339, 1-12.

Walker, M.J.C. 1984. Pollen analysis and Quaternary research in Scotland. Quaternary science reviews 3, 369-404.

Walker, M.J.C. 1995. Climatic changes in Europe during the last glacial/interglacial transition. Quaternary International 28, 63-76.

Walker, M., Lowe, J., 2017. Lateglacial environmental change in Scotland. Earth and Environmental Science Transactions of The Royal Society of Edinburgh 1-26. 
Walker, M.J.C., Björck, S., Lowe, J.J., Cwynar, L.C., Johnsen, S., Knudsen, K.L., Wohlfarth, B. INTIMATE Group. 1999. Isotopic 'events' in the GRIP ice core: a stratotype for the Late Pleistocene. Quaternary Science Reviews 18, 1143-1150.

2505

Wastegård, S. 2002. Early to middle Holocene silicic tephra horizons from the Katla volcanic system, Iceland: new results from the Faroe Islands. Journal of Quaternary Science 17, 723730.

Wastegård, S., Turney, C.S.M., Lowe, J.J. Roberts, S.J. 2000. New discoveries of the Vedde Ash in southern Sweden and Scotland. Boreas 29, 72-78.

Wastegård, S., Veres, D., Kliem, P., Hahn, A., Ohlendorf, C., Zolitschka, B., The PASADO SAcience Team. 2013. Towards a late Quaternary tephrochronological framework for the southernmost part of South America - the Laguna Potrok Aike tephra record. Quaternary Science Reviews 71, 81-90.

Wastegård, S., Gudmundsdóttir, E.R., Lind, E.M., Timms, R.G.O., Björck, S., Hannon, G.E.,

Olsen, J., Rundgren, M. 2018. Towards a Holocene tephrochronology for the Faroe Islands, North Atlantic. Quaternary Science Reviews 195, 195-214.

Watson, J.E., Brooks, S.J., Whitehouse, N.J., Reimer, P.J., Birks, H.J.B. Turney, C. 2010. Chironomid-inferred late-glacial summer air temperatures from Lough Nadourcan, Co.

Donegal, Ireland. Journal of Quaternary Science. 25, 1200-1210.

Watson, E.J., Kołaczek, P., Słowiński, M., Swindles, G.T., Marcisz, K., Gałka, M., Lamentowicz, M. 2017. First discovery of Holocene Alaskan and Icelandic tephra in Polish 2528 peatlands. Journal of Quaternary Science 32, 457-462.

Weston, D.J. 2012. A tephrostratigraphic study of the Late Glacial to Interglacial Transition on Tanera Mòr, Summer Isles, Northwestern Scotland. Unpublished MSc thesis, University of London.

Whittington, G., Edwards, K.J., Zanchetta, G., Keen, D.H., Bunting, M.J., Fallick, A.E. Bryant, C.L. 2015. Lateglacial and early Holocene climates of the Atlantic margins of Europe: Stable isotope, mollusc and pollen records from Orkney, Scotland. Quaternary Science Reviews 122, 112-130. 
2539 Williams, A.N., Lowe, J.J., Turney, C.S.M., Woodcock, P. 2007. Preliminary tephrostratigraphical investigations at Traeth Mawr. In: Quaternary of the Brecon Beacons

Field Guide. ed by. Carr, S.J., Coleman, C.G., Humpage, A.J., Shakesby, R.A., Quaternary Research Association, 151-158.

Wohlfarth, B., Blaauw, M., Davies, S.M., Andersson, M., Wastegard, S., Hormes, A.

Possnert, G. 2006. Constraining the age of Lateglacial and early Holocene pollen zones and tephra horizons in southern Sweden with Bayesian probability methods. Journal of

Quaternary Science 21, 321-334.

Wulf, S., Ott, F., Słowinski, M., Noryskiewicz, A. M., Dräger, N., Martin-Puertas, C., Czymzik, M., Neugebauer, I., Dulski, P., Bourne, A. J., Błaszkiewicz, M., Brauer, A. 2013. Tracing the Laacher See Tephra in the varved sediment record of the Trzechowskie palaeolake in central Northern Poland. Quaternary Science Reviews 76, 129-139.

Wulf, S., Dräger, N., Ott, F., Serb, J., Appelt, O., Guðmundsdóttir, E., van den Bogaard, C., 2555 Słowiński, M., Błaszkiewicz, M., Brauer, A. 2016. Holocene tephrostratigraphy of varved sediment records from Lakes Tiefer See (NE Germany) and Czechowskie (N Poland). Quaternary Science Reviews 132, 1-14.

Wulf, S., Hardiman, M.J., Staff, R.A., Koutsodendris, A., Appelt, O., Blockley, S.P., Lowe, J.J., Manning, C.J., Ottolini, L., Schmitt, A.K. and Smith, V.C., Tomlinson, E.L., 2561 Vakhrameeva, P., Knipping, M., Kotthoff, U., Milner, A.M., Müller, U.C., Christanis, K., 2562 Kalaitzidia, S., Tzedakis, P.C., Schmiedl, G., Pross, J. 2018. The marine isotope stage 1-5 2563 cryptotephra record of Tenaghi Philippon, Greece: Towards a detailed tephrostratigraphic 

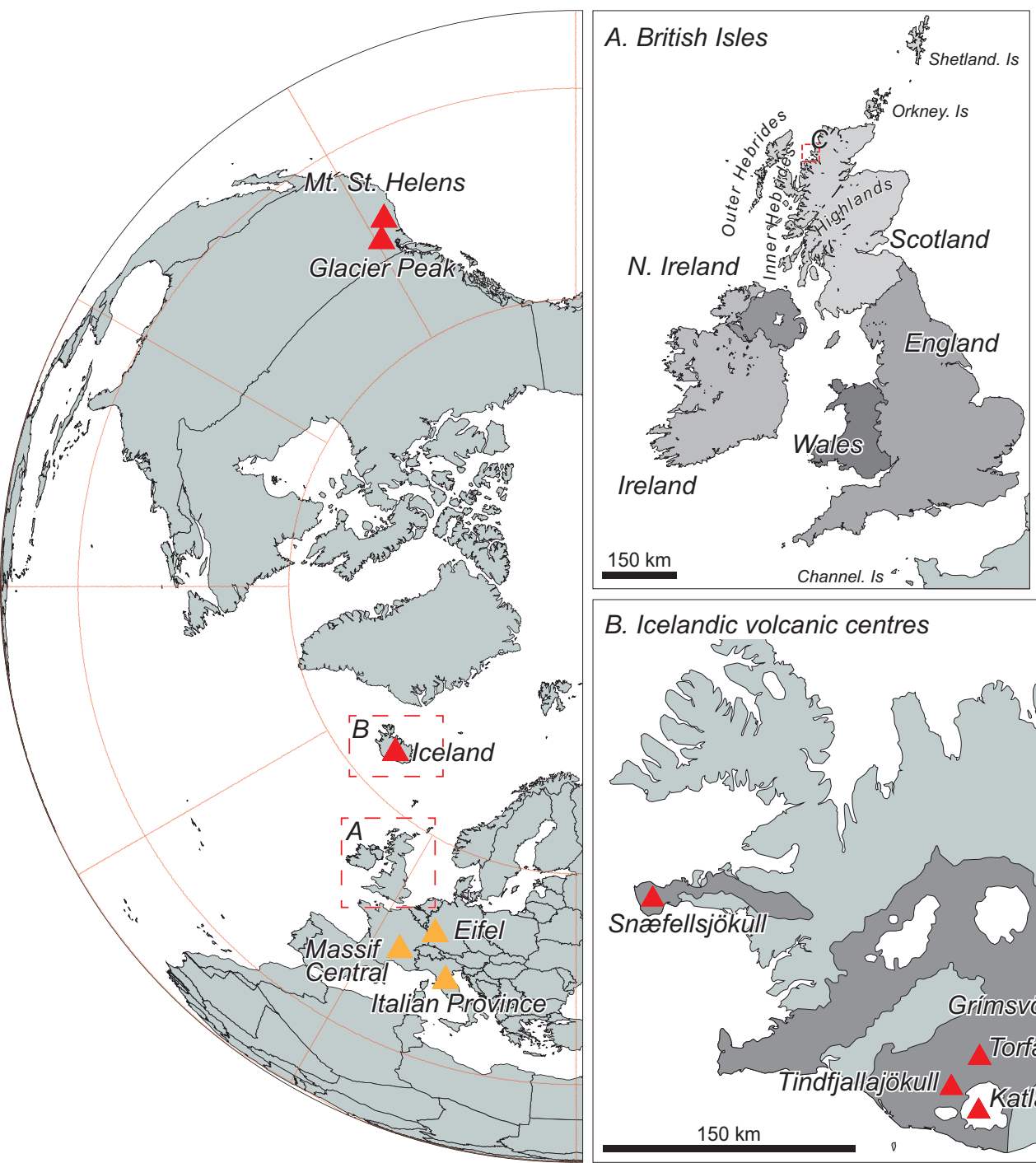

Proposed source of tephra

reaching the British Isles during the LGIT

Other volcanic centres

contributing to the European

tephra framework

(see Lowe et al., 2015)

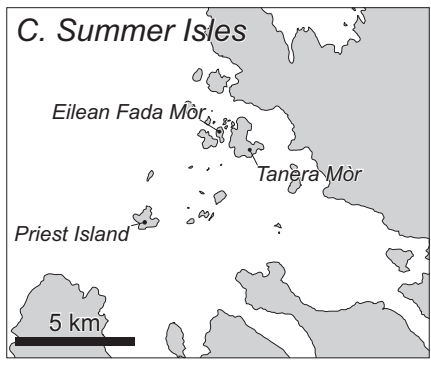

B. Icelandic volcanic centres 。

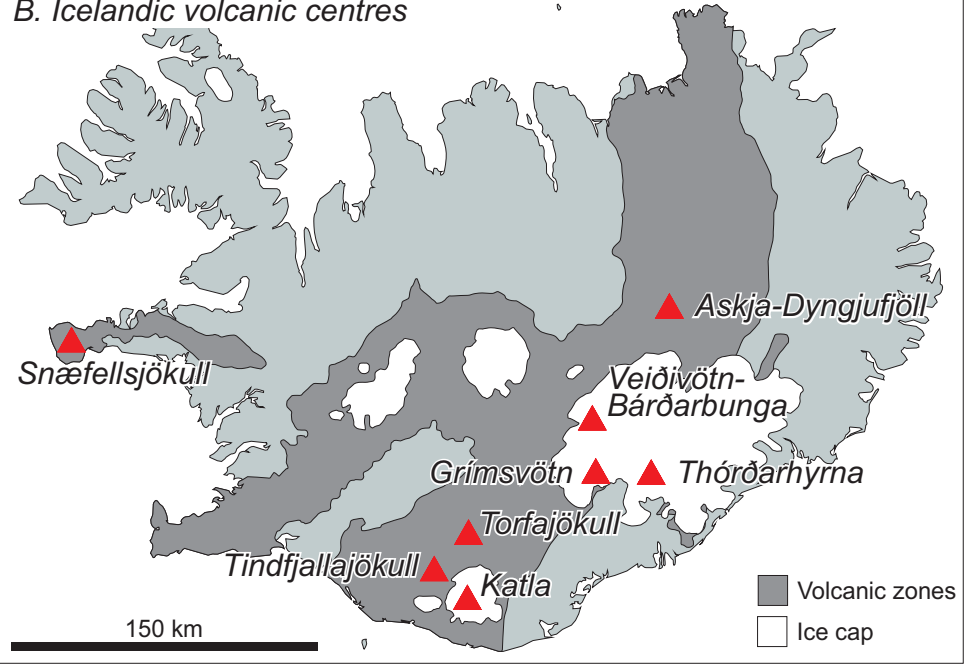




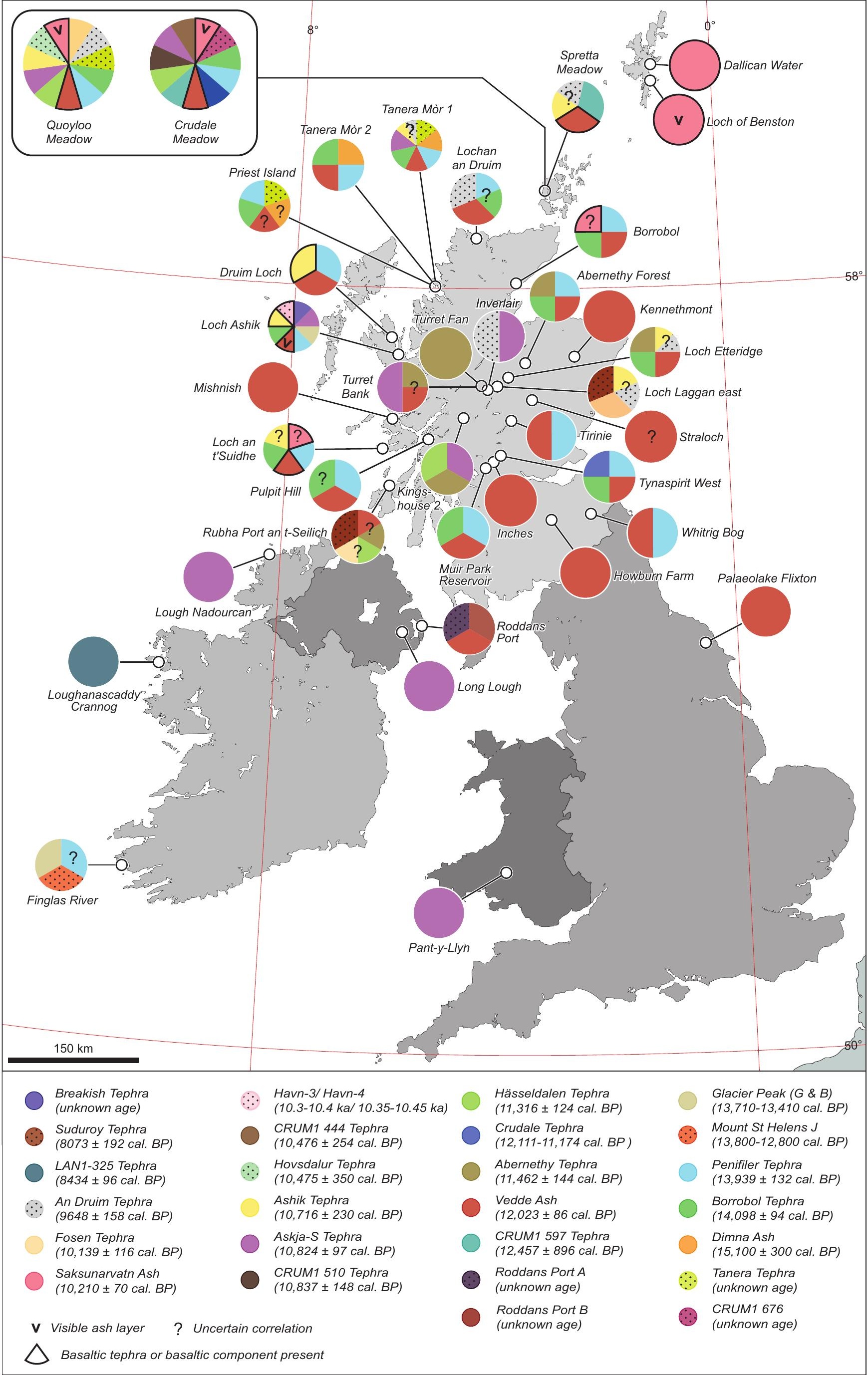


NGRIP $\delta^{18} \mathrm{O} \%$

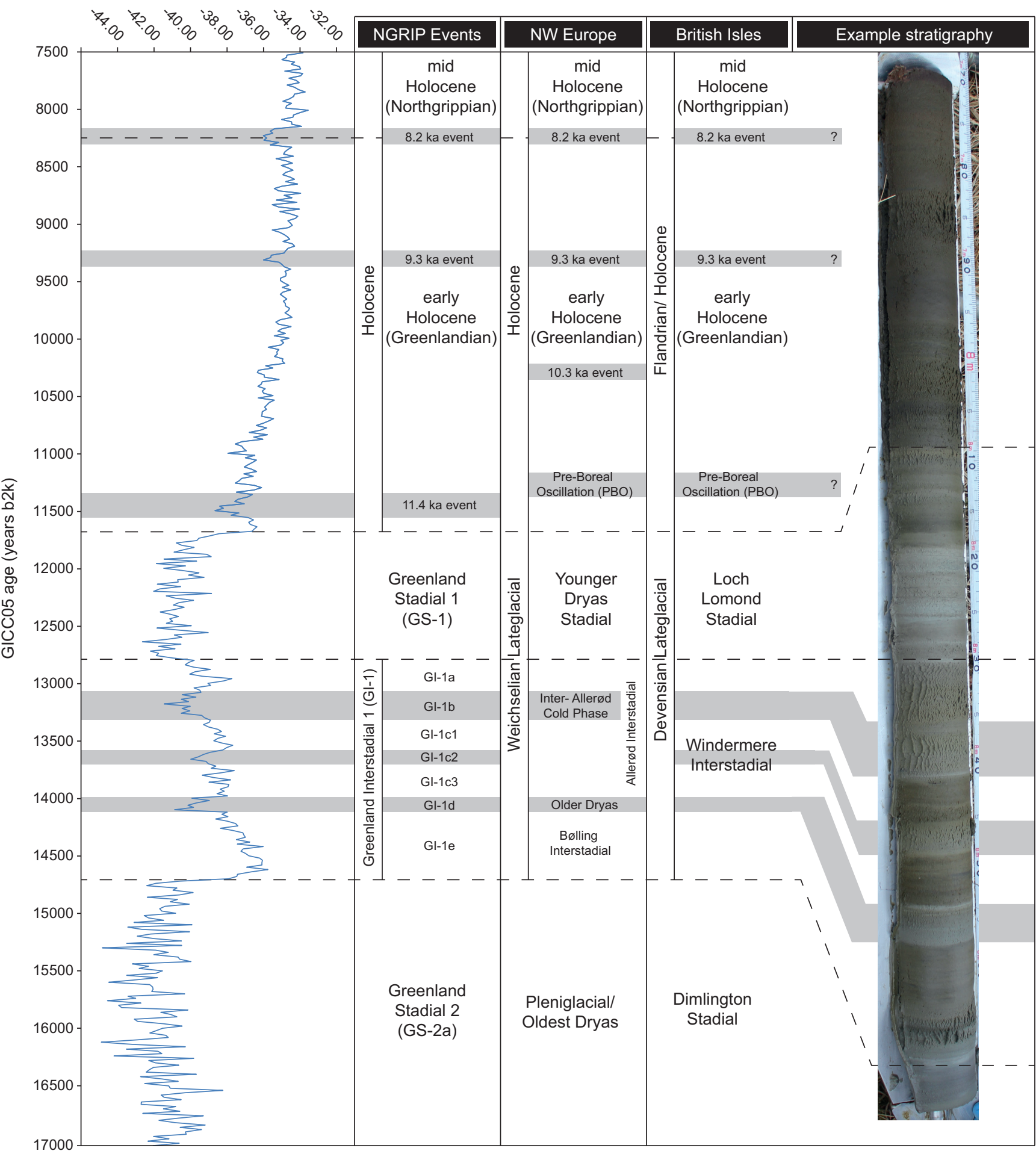



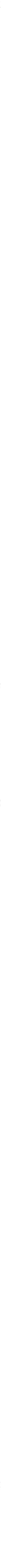

Penifiler Tephra

Borrobol Tephra

GS-2 Borrobol-type

Dimna Ash
* TM2 504 (Weston 2012)

\ TM1 553 (Timms 2016)

$\diamond$ TM1 545 (Timms 2016)

十 QM1 242 (Timms 2016)

$\triangle P R I 700$ (Valentine 2012) 
A. Borrobol 1997

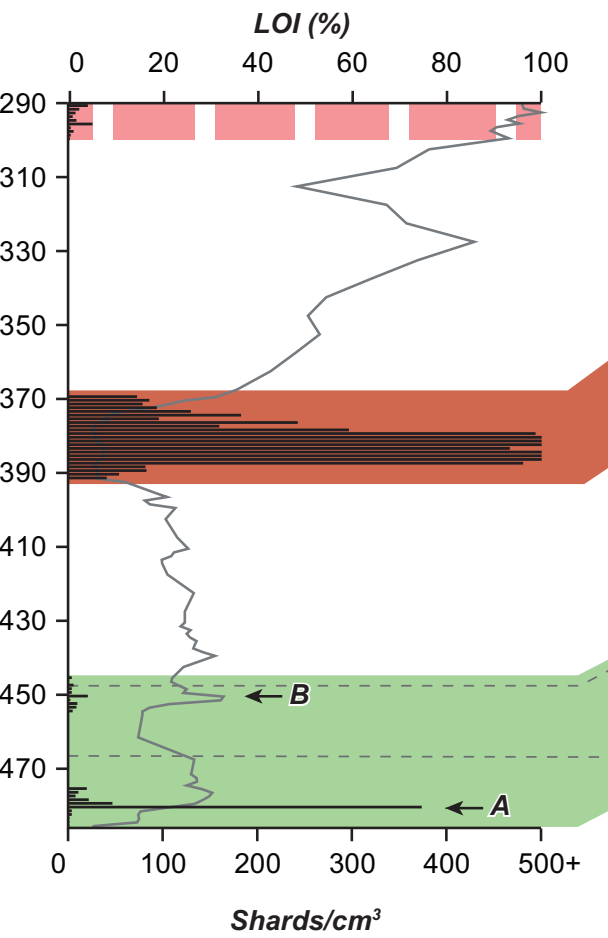

B. Borrobol 2007

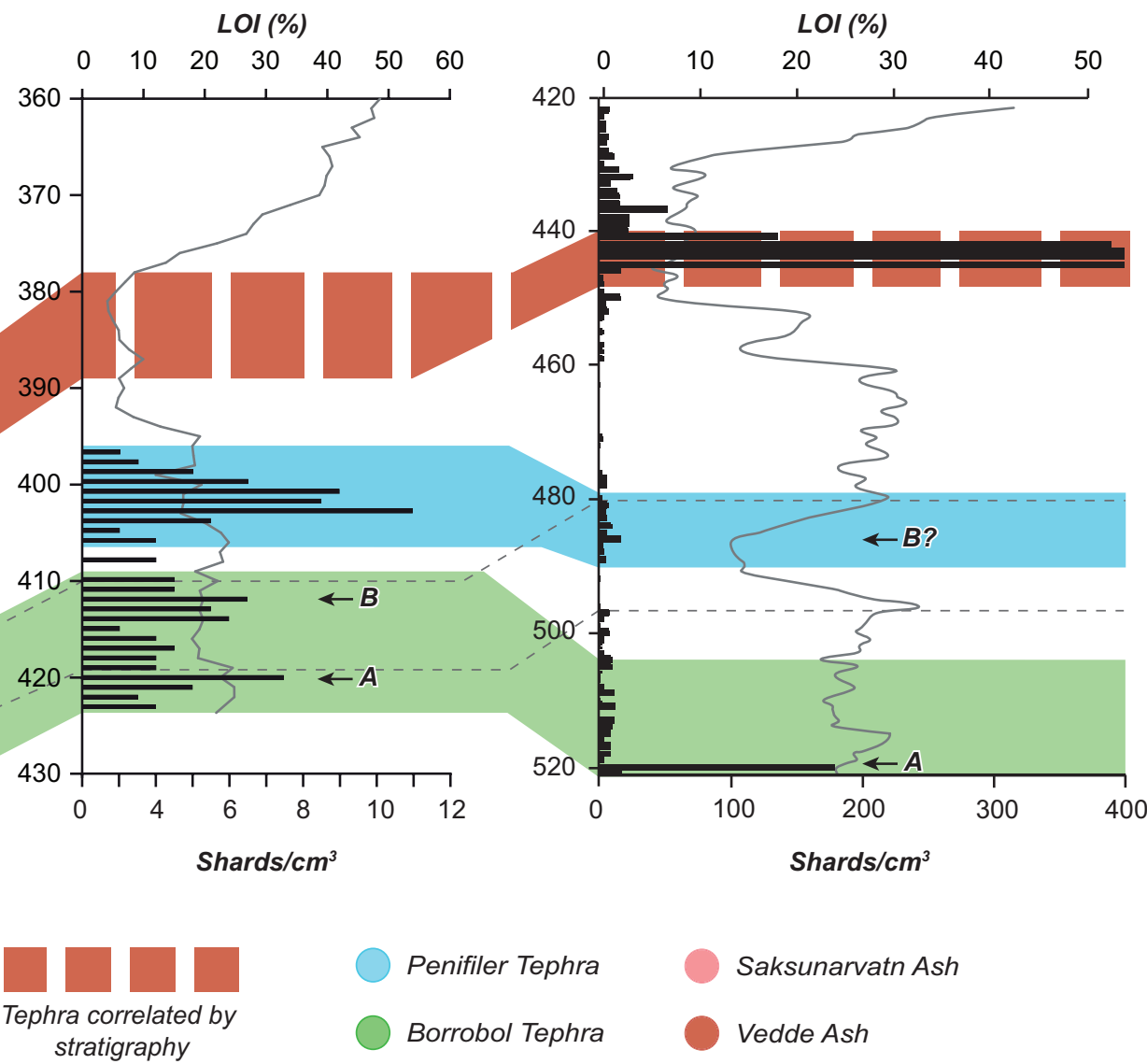
stratigraphy
Tephra correlated by chemical analyses 

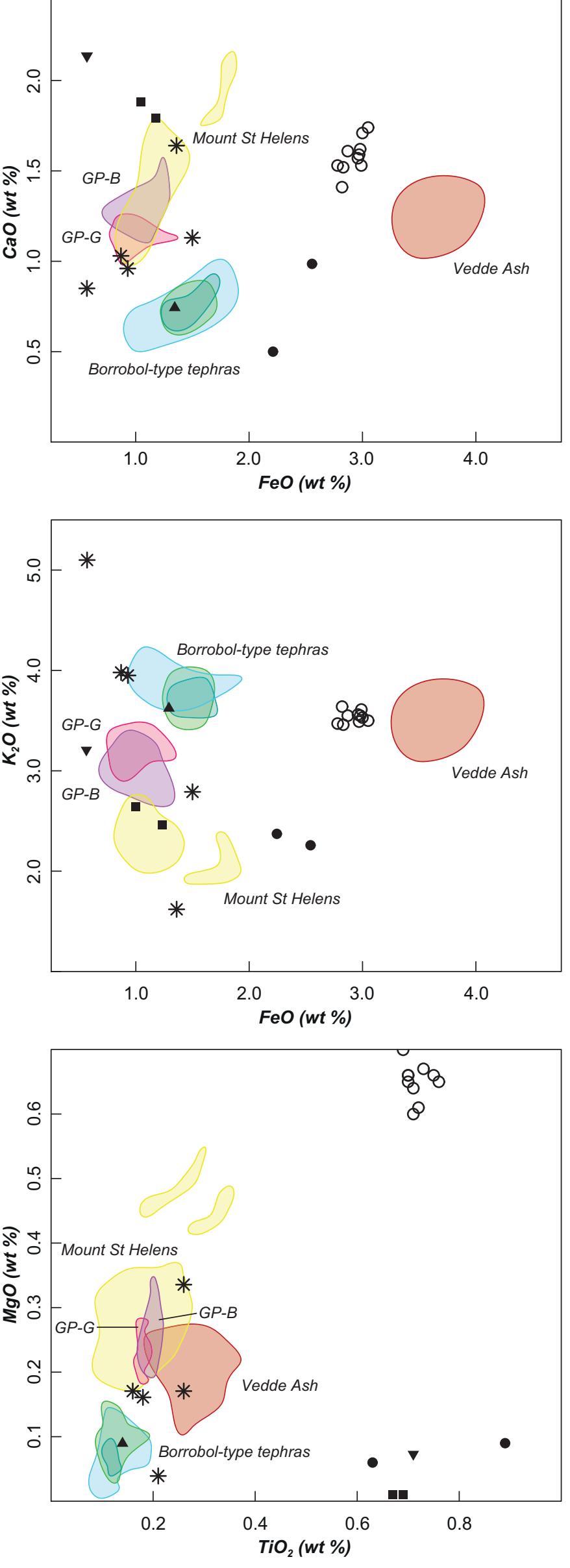

- $L A S-1(A)$ - LAS-1(B) $\boldsymbol{a} L A S-1(C) \nabla L A S-1(D)$ (Davies, 2002)

$\bigcirc$ Roddans Port $A \quad$ * Roddans Port B (Turney et al., 2006)

Vedde Ash

CRUM1 597 Tephra

Glacier Peak G

Penifiler Tephra $\bigcirc$ Glacier Peak B

Borrobol Tephra Mount St Helens (Swift Creek) 



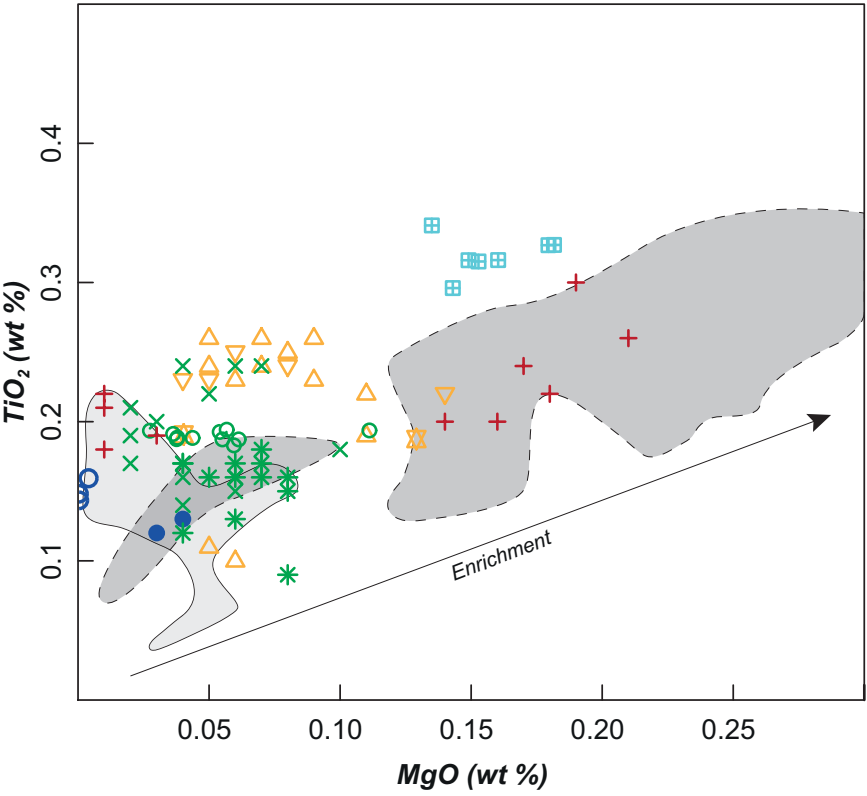

Torfajökull (Pleistocene)

Torfajökull (Holocene)

\section{LAN1-325 Tephra}

$\boxplus$ Loughanascaddy Crannog (Matthews, 2008)

\section{An Druim-Høvdarhagi Tephra}

* Lochan An Druim S13 (Ranner et al., 2005)

× Inverlair B (Kelly et al., 2017)

- Quoyloo Meadow 133 (Timms et al., 2017)

+ Høvdarhagi 217 (Lind and Wastegård, (2011)

\section{Ashik Tephra}

$\nabla$ Loch Ashik 882 (Pyne-O'Donnell, 2007)

$\triangle$ Druim Loch 1013 (Pyne-O’Donnell, 2007)

Quoyloo Meadow 187 (Timms et al., 2017)

\section{Crudale Tephra}

O CRUM1 561 (Timms et al., 2018)

- Tynaspirit West 754 (Roberts, 1997) 


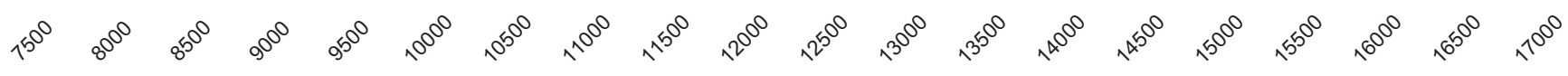

Holocene

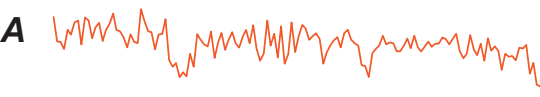

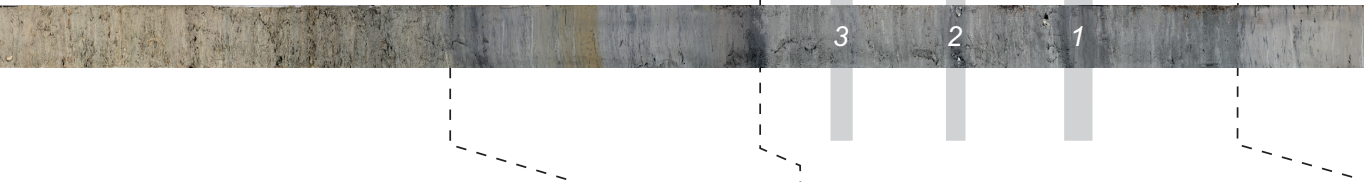

\section{c}

D

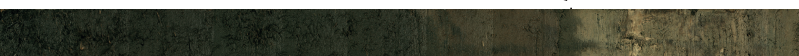

suphoping
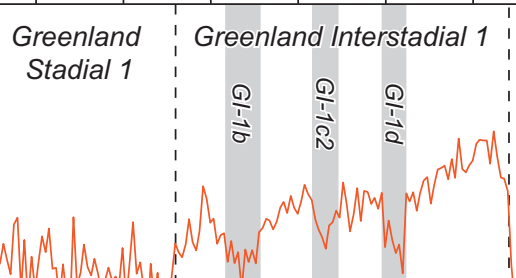

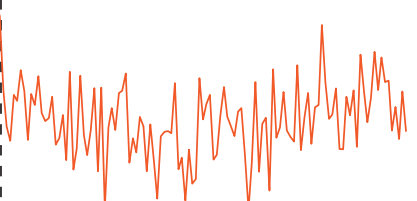

$-38$

$-42$

$-42$

$E$

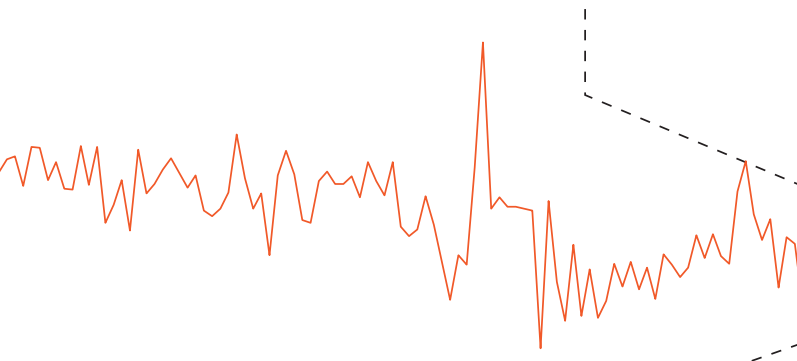

(ii)

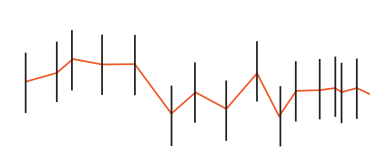

$F$

(iii),

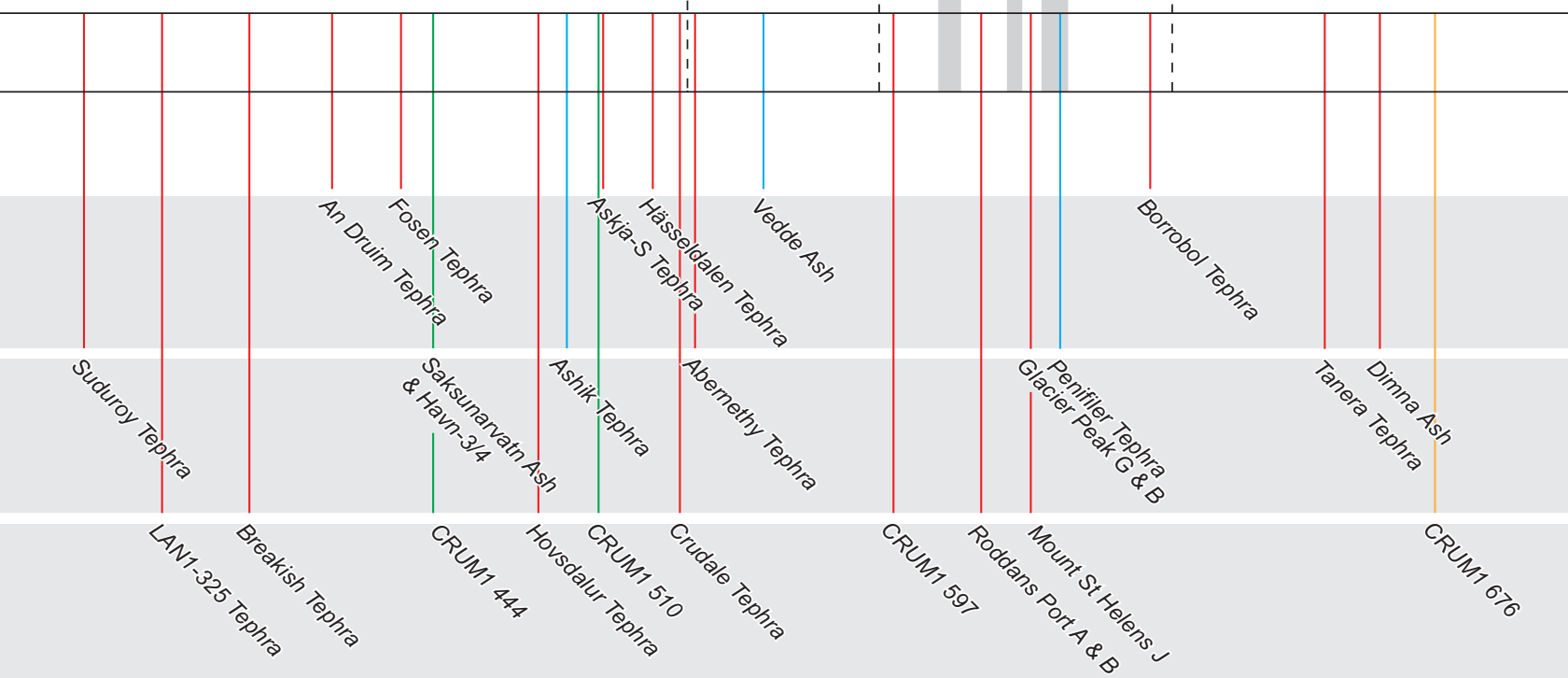




\section{Table 1}

Combined non-normalised glass-shard analytical data of tephras identified in the British Isles dating to the Last Glacial to Interglacial Transition (LGIT c. 16-8 ka BP). The value shown in the 'Number of sites' row relates only to those locations where correlations are secure: see Supplementary Table S1 for further details on the number of tentative correlations for each tephra. Mean glass data derived from: Roberts, (1997); Turney et al. (1997); Darville, (2011); Davies et al. (2001); Mackie et al. (2002); Ranner et al. (2005); Pyne-O'Donnell, (2007), Matthews, (2008); Pyne-O'Donnell et al. (2008); Matthews et al. (2011); Lane et al. (2012a); Weston, (2012); MacLeod et al. (2015); Mithen et al. (2015); Lind et al. (2016); Timms, (2016); Jones et al. (2017); Kelly et al. (2017); Lowe et al., (2017); Timms et al. (2017, 2018); Lowe et al. (in prep). Glass compositional data are available in full from Supplementary Table S2.

\begin{tabular}{|c|c|c|c|c|c|c|c|c|c|c|c|c|}
\hline Tephra name & \multicolumn{2}{|l|}{$\begin{array}{l}\text { CRUM1 } 676 \\
\text { Tephra }\end{array}$} & \multicolumn{2}{|c|}{ Dimna Ash } & \multicolumn{2}{|c|}{ Tanera Tephra } & \multicolumn{2}{|c|}{ Borrobol Tephra } & \multicolumn{2}{|c|}{$\begin{array}{l}\text { Penifiler Tephra } \\
\text { (R) }\end{array}$} & \multicolumn{2}{|c|}{$\begin{array}{l}\text { Penifiler Tephra } \\
\text { (B) }\end{array}$} \\
\hline $\begin{array}{l}\text { Number of sites in } \\
\text { British Isles }\end{array}$ & \multicolumn{2}{|l|}{1} & \multicolumn{2}{|l|}{2} & \multicolumn{2}{|l|}{3} & \multicolumn{2}{|l|}{13} & \multicolumn{2}{|c|}{15} & \multicolumn{2}{|c|}{1} \\
\hline $\begin{array}{l}\text { Identified outside } \\
\text { British Isles? }\end{array}$ & \multicolumn{2}{|l|}{ no } & \multicolumn{2}{|l|}{ yes } & \multicolumn{2}{|c|}{ uncertain } & \multicolumn{2}{|l|}{ yes } & \multicolumn{2}{|c|}{ uncertain } & \multicolumn{2}{|c|}{ uncertain } \\
\hline $\begin{array}{l}\text { Current best age } \\
\text { estimate }\end{array}$ & \multicolumn{2}{|l|}{ unknown } & \multicolumn{2}{|c|}{$\begin{array}{l}15,100 \pm 300 \text { cal. } \\
\text { BP }\end{array}$} & \multicolumn{2}{|c|}{ unknown } & \multicolumn{2}{|c|}{$14,098 \pm 94$ cal. BP } & \multicolumn{2}{|c|}{$\begin{array}{l}13,939 \pm 132 \text { cal. } \\
\text { BP }\end{array}$} & \multicolumn{2}{|c|}{$\begin{array}{l}13,939 \pm 132 \text { cal. } \\
\text { BP }\end{array}$} \\
\hline $\begin{array}{l}\text { Reference for age } \\
\text { estimate }\end{array}$ & \multicolumn{2}{|l|}{$\mathrm{N} / \mathrm{A}$} & \multicolumn{2}{|c|}{ Koren et al. (2008) } & \multicolumn{2}{|l|}{$\mathrm{N} / \mathrm{A}$} & \multicolumn{2}{|c|}{$\begin{array}{l}\text { Bronk Ramsey et } \\
\text { al. }(2015)\end{array}$} & \multicolumn{2}{|c|}{$\begin{array}{l}\text { Bronk Ramsey et } \\
\text { al. }(2015)\end{array}$} & \multicolumn{2}{|c|}{$\begin{array}{l}\text { Bronk Ramsey et } \\
\text { al. }(2015)\end{array}$} \\
\hline Source & \multicolumn{2}{|l|}{ unknown } & \multicolumn{2}{|c|}{ Katla, Iceland } & \multicolumn{2}{|c|}{ unknown, Iceland } & \multicolumn{2}{|c|}{ unknown, Iceland } & \multicolumn{2}{|c|}{ unknown } & Katla, & \\
\hline Chemical composition & Dacite & & Rhyol & & Rhyoli & & Rhyolit & & Rhyolite & & Basalt & \\
\hline Major oxide (wt \%) & $\mathrm{n}=1$ & $2 \sigma$ & $n=8$ & $2 \sigma$ & $\mathrm{n}=11$ & $2 \sigma$ & $n=243$ & $2 \sigma$ & $\mathrm{n}=177$ & $2 \sigma$ & $\mathrm{n}=12$ & $2 \sigma$ \\
\hline $\mathrm{SiO} 2$ & 62.15 & 0.56 & 70.32 & 3.01 & 72.59 & 2.72 & 73.21 & 1.49 & 73.49 & 2.12 & 47.31 & 0.85 \\
\hline $\mathrm{TiO} 2$ & 1.24 & 0.02 & 0.27 & 0.01 & 0.13 & 0.02 & 0.12 & 0.04 & 0.11 & 0.04 & 4.60 & 0.29 \\
\hline $\mathrm{Al} 2 \mathrm{O} 3$ & 15.00 & 0.88 & 13.26 & 0.64 & 12.31 & 0.71 & 12.28 & 0.56 & 12.23 & 0.65 & 13.11 & 0.19 \\
\hline $\mathrm{FeO}$ & 5.12 & 0.38 & 3.73 & 0.32 & 1.54 & 0.20 & 1.48 & 0.19 & 1.33 & 0.40 & 14.81 & 0.25 \\
\hline $\mathrm{MnO}$ & 0.14 & 0.00 & 0.14 & 0.03 & 0.04 & 0.04 & 0.04 & 0.04 & 0.04 & 0.05 & - & - \\
\hline $\mathrm{MgO}$ & 1.42 & 0.00 & 0.17 & 0.06 & 0.08 & 0.07 & 0.08 & 0.06 & 0.06 & 0.06 & 5.03 & 0.17 \\
\hline $\mathrm{CaO}$ & 3.67 & 0.39 & 1.28 & 0.12 & 0.82 & 0.10 & 0.75 & 0.11 & 0.68 & 0.20 & 9.85 & 0.28 \\
\hline $\mathrm{Na} 2 \mathrm{O}$ & 5.12 & 0.83 & 5.20 & 0.22 & 4.00 & 0.44 & 3.83 & 0.80 & 3.89 & 0.88 & 3.09 & 0.25 \\
\hline
\end{tabular}




\begin{tabular}{|c|c|c|c|c|c|c|c|c|c|c|c|c|}
\hline $\mathrm{K} 2 \mathrm{O}$ & 2.47 & 0.12 & 3.58 & 0.33 & 3.82 & 0.31 & 3.76 & 0.24 & 3.89 & 0.63 & 0.78 & 0.07 \\
\hline P2O5 & 0.93 & 0.15 & 0.18 & 0.01 & 0.02 & 0.02 & 0.01 & 0.01 & 0.02 & 0.12 & - & - \\
\hline $\mathrm{Cl}$ & - & - & 0.03 & 0.00 & 0.13 & 0.03 & 0.06 & 0.12 & 0.13 & 0.02 & - & - \\
\hline Total & 97.26 & 1.44 & 98.04 & 3.26 & 95.39 & 3.19 & 95.59 & 1.81 & 95.74 & 2.26 & 98.58 & 1.30 \\
\hline Tephra name & \multicolumn{2}{|c|}{$\begin{array}{l}\text { Mount St Helens J } \\
\text { Tephra }\end{array}$} & \multicolumn{2}{|c|}{$\begin{array}{l}\text { Glacier Peak-G } \\
\text { Tephra }\end{array}$} & \multicolumn{2}{|c|}{$\begin{array}{l}\text { Roddans Port A } \\
\text { Tephra }\end{array}$} & \multicolumn{2}{|c|}{$\begin{array}{l}\text { Roddans Port B } \\
\text { Tephra }\end{array}$} & \multicolumn{2}{|c|}{$\begin{array}{l}\text { CRUM1 } 597 \\
\text { Tephra }\end{array}$} & \multicolumn{2}{|c|}{ Vedde Ash (R) } \\
\hline $\begin{array}{l}\text { Number of sites in } \\
\text { British Isles }\end{array}$ & \multicolumn{2}{|l|}{1} & \multicolumn{2}{|l|}{2} & \multicolumn{2}{|l|}{1} & \multicolumn{2}{|c|}{1} & \multicolumn{2}{|l|}{2} & \multicolumn{2}{|l|}{23} \\
\hline $\begin{array}{l}\text { Identified outside } \\
\text { British Isles? }\end{array}$ & \multicolumn{2}{|l|}{ yes } & \multicolumn{2}{|l|}{ yes } & \multicolumn{2}{|l|}{ no } & \multicolumn{2}{|l|}{ no } & \multicolumn{2}{|l|}{ no } & \multicolumn{2}{|l|}{ yes } \\
\hline $\begin{array}{l}\text { Current best age } \\
\text { estimate }\end{array}$ & \multicolumn{2}{|c|}{$\begin{array}{l}13.86-12.80 \text { cal. ka } \\
\text { BP }\end{array}$} & \multicolumn{2}{|c|}{$\begin{array}{l}\text { 13,710-13,410 cal. } \\
\text { BP }\end{array}$} & \multicolumn{2}{|c|}{ unknown } & \multicolumn{2}{|c|}{ unknown } & \multicolumn{2}{|c|}{$\begin{array}{l}12,457 \pm 896 \text { cal. } \\
\text { BP }\end{array}$} & \multicolumn{2}{|c|}{$\begin{array}{l}12,023 \pm 86 \text { cal. } \\
\mathrm{BP}\end{array}$} \\
\hline $\begin{array}{l}\text { Reference for age } \\
\text { estimate }\end{array}$ & \multicolumn{2}{|c|}{ Clynne et al. (2008) } & \multicolumn{2}{|c|}{ Kuehn et al. (2009) } & \multicolumn{2}{|c|}{ Turney et al. (2006) } & \multicolumn{2}{|c|}{ Turney et al. (2006) } & \multicolumn{2}{|c|}{ Timms et al. (2018) } & \multicolumn{2}{|c|}{$\begin{array}{l}\text { Bronk Ramsey et } \\
\text { al. (2015) }\end{array}$} \\
\hline Source & \multicolumn{2}{|c|}{ Mount St Helens } & Glacie & USA & unkno & & unkno & & unkno & & Katla, I & \\
\hline Chemical composition & Rhyolite & & Rhyol & & Rhyol & & Rhyoli & & Rhyol & & Rhyolit & \\
\hline Major oxide (wt \%) & $\mathrm{n}=1$ & $2 \sigma$ & $n=2$ & $2 \sigma$ & $n=10$ & $2 \sigma$ & $\mathrm{n}=5$ & $2 \sigma$ & $\mathrm{n}=29$ & $2 \sigma$ & $n=428$ & $2 \sigma$ \\
\hline $\mathrm{SiO} 2$ & 72.88 & - & 73.03 & 2.67 & 68.99 & 2.23 & 75.08 & 2.71 & 73.32 & 0.73 & 70.36 & 2.58 \\
\hline TiO2 & 0.24 & - & 0.22 & 0.07 & 0.72 & 0.05 & 0.21 & 0.09 & 0.12 & 0.01 & 0.28 & 0.07 \\
\hline $\mathrm{Al} 2 \mathrm{O} 3$ & 12.82 & - & 11.84 & 0.71 & 16.15 & 1.67 & 12.47 & 1.04 & 12.03 & 0.46 & 13.19 & 0.76 \\
\hline $\mathrm{FeO}$ & 1.15 & - & 0.95 & 0.08 & 2.93 & 0.18 & 1.05 & 0.76 & 1.47 & 0.23 & 3.69 & 0.32 \\
\hline $\mathrm{MnO}$ & 0.05 & - & 0.03 & 0.08 & - & - & & & 0.04 & 0.02 & 0.14 & 0.06 \\
\hline $\mathrm{MgO}$ & 0.31 & - & 0.26 & 0.06 & 0.65 & 0.06 & 0.18 & 0.21 & 0.07 & 0.05 & 0.20 & 0.06 \\
\hline $\mathrm{CaO}$ & 1.34 & - & 1.12 & 0.18 & 1.58 & 0.19 & 1.12 & 0.61 & 0.74 & 0.14 & 1.25 & 0.18 \\
\hline $\mathrm{Na} 2 \mathrm{O}$ & 3.76 & - & 3.10 & 0.03 & 4.97 & 0.49 & 3.24 & 1.59 & 4.11 & 0.28 & 4.73 & 1.19 \\
\hline $\mathrm{K} 2 \mathrm{O}$ & 2.09 & - & 3.12 & 0.55 & 3.54 & 0.12 & 3.49 & 2.65 & 3.73 & 0.20 & 3.50 & 0.27 \\
\hline $\mathrm{P} 2 \mathrm{O} 5$ & & - & - & - & - & - & - & - & - & - & 0.04 & 0.03 \\
\hline $\mathrm{Cl}$ & & - & - & - & - & - & - & - & 0.01 & 0.01 & 0.18 & 0.05 \\
\hline Total & 94.64 & - & 93.66 & 3.18 & 99.54 & 1.26 & 96.83 & 3.39 & 95.64 & 1.08 & 97.42 & 3.34 \\
\hline
\end{tabular}




\begin{tabular}{|c|c|c|c|c|c|c|c|c|c|c|c|c|}
\hline Tephra name & \multicolumn{2}{|c|}{ Vedde Ash (B) } & \multicolumn{2}{|c|}{$\begin{array}{l}\text { Abernethy Tephra } \\
\text { (pop A) }\end{array}$} & \multicolumn{2}{|c|}{$\begin{array}{l}\text { Abernethy Tephra } \\
\text { (pop B) }\end{array}$} & \multicolumn{2}{|c|}{ Crudale Tephra } & \multicolumn{2}{|c|}{$\begin{array}{l}\text { Hässeldalen } \\
\text { Tephra }\end{array}$} & \multicolumn{2}{|c|}{ Askja-S Tephra } \\
\hline $\begin{array}{l}\text { Number of sites in } \\
\text { British Isles }\end{array}$ & \multicolumn{2}{|l|}{5} & \multicolumn{2}{|c|}{4} & \multicolumn{2}{|c|}{3} & \multicolumn{2}{|l|}{2} & \multicolumn{2}{|c|}{3} & \multicolumn{2}{|l|}{10} \\
\hline $\begin{array}{l}\text { Identified outside } \\
\text { British Isles? }\end{array}$ & \multicolumn{2}{|l|}{ yes } & \multicolumn{2}{|c|}{ uncertain } & \multicolumn{2}{|c|}{ uncertain } & \multicolumn{2}{|l|}{ no } & \multicolumn{2}{|l|}{ yes } & \multicolumn{2}{|l|}{ yes } \\
\hline $\begin{array}{l}\text { Current best age } \\
\text { estimate }\end{array}$ & \multicolumn{2}{|c|}{$12,023 \pm 86$ cal. BP } & \multicolumn{2}{|c|}{$\begin{array}{l}11,462 \pm 144 \text { cal. } \\
\text { BP }\end{array}$} & \multicolumn{2}{|c|}{$\begin{array}{l}11,462 \pm 144 \text { cal. } \\
\text { BP }\end{array}$} & \multicolumn{2}{|c|}{$\begin{array}{l}\text { 12,111 - 11,174 } \\
\text { cal. BP }\end{array}$} & \multicolumn{2}{|c|}{$\begin{array}{l}11,316 \pm 124 \text { cal. } \\
\mathrm{BP}\end{array}$} & \multicolumn{2}{|c|}{$\begin{array}{l}10,824 \pm 97 \text { cal. } \\
\text { BP }\end{array}$} \\
\hline $\begin{array}{l}\text { Reference for age } \\
\text { estimate }\end{array}$ & \multicolumn{2}{|c|}{$\begin{array}{l}\text { Bronk Ramsey et } \\
\text { al. (2015) }\end{array}$} & \multicolumn{2}{|c|}{$\begin{array}{l}\text { Bronk Ramsey et } \\
\text { al. }(2015)\end{array}$} & \multicolumn{2}{|c|}{$\begin{array}{l}\text { Bronk Ramsey et } \\
\text { al. (2015) }\end{array}$} & \multicolumn{2}{|c|}{ Timms et al. (2018) } & \multicolumn{2}{|c|}{$\begin{array}{l}\text { Wastegård et al. } \\
\text { (2018) }\end{array}$} & \multicolumn{2}{|c|}{$\begin{array}{l}\text { Kearney et al. } \\
(2018)\end{array}$} \\
\hline Source & \multicolumn{2}{|c|}{ Katla, Iceland } & Katla, & & Unkno & land & Torfajc் & eland & $\begin{array}{l}\text { Thórda } \\
\text { Icelan }\end{array}$ & & $\begin{array}{l}\text { Askja-[ } \\
\text { Iceland }\end{array}$ & fjöll, \\
\hline Chemical composition & Basaltic & & Rhyoli & & Rhyoli & & Rhyoli & & Rhyoli & & Rhyolit & \\
\hline Major oxide (wt \%) & $n=106$ & $2 \sigma$ & $\mathrm{n}=33$ & $2 \sigma$ & $n=8$ & $2 \sigma$ & $\mathrm{n}=5$ & $2 \sigma$ & $\mathrm{n}=23$ & $2 \sigma$ & $n=177$ & $2 \sigma$ \\
\hline $\mathrm{SiO} 2$ & 46.74 & 1.49 & 71.10 & 2.63 & 74.12 & 1.07 & 73.70 & 2.50 & 74.13 & 2.11 & 73.45 & 2.93 \\
\hline $\mathrm{TiO} 2$ & 4.55 & 0.31 & 0.27 & 0.02 & 0.09 & 0.04 & 0.15 & 0.04 & 0.08 & 0.01 & 0.30 & 0.04 \\
\hline $\mathrm{Al} 2 \mathrm{O} 3$ & 12.66 & 0.93 & 13.18 & 0.72 & 12.79 & 0.60 & 11.64 & 0.71 & 11.64 & 0.98 & 11.85 & 0.69 \\
\hline $\mathrm{FeO}$ & 14.59 & 1.39 & 3.67 & 0.29 & 1.49 & 0.25 & 2.55 & 0.25 & 1.08 & 0.18 & 2.52 & 0.23 \\
\hline $\mathrm{MnO}$ & 0.22 & 0.08 & 0.15 & \begin{tabular}{|l|}
0.02 \\
\end{tabular} & 0.06 & 0.02 & 0.06 & 0.04 & 0.04 & 0.02 & 0.09 & 0.04 \\
\hline $\mathrm{MgO}$ & 5.01 & 0.51 & 0.19 & 0.04 & 0.05 & 0.05 & 0.01 & 0.04 & 0.04 & 0.05 & 0.24 & 0.05 \\
\hline $\mathrm{CaO}$ & 9.68 & 0.69 & 1.24 & 0.11 & 0.74 & 0.08 & 0.38 & 0.04 & 0.52 & 0.24 & 1.59 & 0.17 \\
\hline $\mathrm{Na} 2 \mathrm{O}$ & 2.98 & 0.44 & 4.91 & 0.70 & 3.92 & 0.50 & 4.52 & 0.51 & 3.68 & 1.25 & 4.16 & 0.61 \\
\hline $\mathrm{K} 2 \mathrm{O}$ & 0.73 & 0.12 & 3.50 & 0.23 & 4.82 & 1.33 & 4.09 & 0.38 & 4.10 & 0.42 & 2.49 & 0.20 \\
\hline $\mathrm{P} 2 \mathrm{O} 5$ & 0.51 & 0.09 & 0.05 & 0.14 & 0.06 & 0.17 & 0.01 & 0.01 & 0.01 & 0.01 & 0.04 & 0.02 \\
\hline $\mathrm{Cl}$ & - & - & 0.01 & 0.04 & 0.00 & 0.01 & - & - & - & - & - & - \\
\hline Total & 97.54 & 2.34 & 98.26 & 3.64 & 98.12 & 2.01 & 97.12 & 2.89 & 95.32 & 2.76 & 96.72 & 3.78 \\
\hline Tephra name & $\begin{array}{l}\text { CRUM1 } \\
\text { Tephra } \\
\end{array}$ & & Ashik & $(R)$ & Ashik & a (B) & Hovsc & phra & $\begin{array}{l}\text { CRUM } \\
\text { Tephr }\end{array}$ & & $\begin{array}{l}\text { Havn-3 } \\
\text { Tephra }\end{array}$ & \\
\hline $\begin{array}{l}\text { Number of sites in } \\
\text { British Isles }\end{array}$ & 1 & & 3 & & 1 & & 1 & & 1 & & 1 & \\
\hline $\begin{array}{l}\text { Identified outside } \\
\text { British Isles? }\end{array}$ & uncertai & & no & & uncert & & yes & & uncert & & yes & \\
\hline
\end{tabular}




\begin{tabular}{|c|c|c|c|c|c|c|c|c|c|c|c|c|}
\hline $\begin{array}{l}\text { Current best age } \\
\text { estimate }\end{array}$ & \multirow{2}{*}{\multicolumn{2}{|c|}{$\begin{array}{l}10,837 \pm 148 \text { cal. } \\
\text { BP } \\
\text { Timms et al. (2018) }\end{array}$}} & \multicolumn{2}{|c|}{$\begin{array}{l}10,716 \pm 230 \text { cal. } \\
\text { BP }\end{array}$} & \multicolumn{2}{|c|}{$\begin{array}{l}10,716 \pm 230 \text { cal. } \\
\text { BP }\end{array}$} & \multicolumn{2}{|c|}{$\begin{array}{l}10,475 \pm 350 \text { cal. } \\
\text { BP }\end{array}$} & \multicolumn{2}{|c|}{$\begin{array}{l}10,476 \pm 254 \text { cal. } \\
\text { BP }\end{array}$} & \multicolumn{2}{|c|}{$\begin{array}{l}\sim 10.37 \text { and } \sim 10.3 \\
\text { ka BP }\end{array}$} \\
\hline $\begin{array}{l}\text { Reference for age } \\
\text { estimate }\end{array}$ & & & Timms & 2017) & Timm & 2017) & Waste & 2002) & Timms & 2018) & $\begin{array}{l}\text { Waste } \\
(2018\end{array}$ & \\
\hline Source & \multicolumn{2}{|c|}{ Grímsvötn, Iceland } & \multicolumn{2}{|c|}{ Torfajökull, Iceland } & \multicolumn{2}{|c|}{ Grímsvötn, Iceland } & \multicolumn{2}{|c|}{$\begin{array}{l}\text { Thordarhyrna, } \\
\text { Iceland }\end{array}$} & \multicolumn{2}{|c|}{ Grímsvötn, Iceland } & \multicolumn{2}{|c|}{ Grímsvötn, Iceland } \\
\hline Chemical composition & \multicolumn{2}{|c|}{ Basaltic } & \multicolumn{2}{|c|}{ Rhyolitic } & \multicolumn{2}{|c|}{ Basaltic } & \multicolumn{2}{|c|}{ Rhyolitic } & \multicolumn{2}{|c|}{ Basaltic } & \multicolumn{2}{|c|}{ Basaltic } \\
\hline Major oxide (wt \%) & $\mathrm{n}=27$ & $2 \sigma$ & $\mathrm{n}=19$ & $2 \sigma$ & $\mathrm{n}=6$ & $2 \sigma$ & $\mathrm{n}=4$ & $2 \sigma$ & $\mathrm{n}=8$ & $2 \sigma$ & $n=31$ & $2 \sigma$ \\
\hline $\mathrm{SiO} 2$ & 49.24 & 0.95 & 71.28 & 2.46 & 49.15 & 2.69 & 75.12 & 2.14 & 48.33 & 1.89 & 48.96 & 1.04 \\
\hline $\mathrm{TiO} 2$ & 3.05 & 0.12 & 0.22 & 0.09 & 3.34 & 1.50 & 0.10 & 0.01 & 3.04 & 0.17 & 3.39 & 0.80 \\
\hline $\mathrm{Al} 2 \mathrm{O} 3$ & 12.80 & 0.71 & 13.31 & 2.51 & 13.26 & 0.75 & 12.09 & 0.58 & 12.76 & 0.86 & 12.85 & 0.59 \\
\hline $\mathrm{FeO}$ & 14.26 & 0.83 & 2.77 & 0.30 & 13.86 & 1.55 & 1.05 & 0.37 & 14.30 & 0.68 & 13.55 & 0.72 \\
\hline $\mathrm{MnO}$ & 0.23 & 0.02 & 0.06 & 0.02 & & 0.00 & 0.03 & 0.01 & 0.23 & 0.01 & 0.21 & 0.08 \\
\hline $\mathrm{MgO}$ & 5.31 & 0.36 & 0.08 & 0.06 & 5.26 & 1.26 & 0.02 & 0.04 & 5.40 & 0.25 & 4.69 & 0.38 \\
\hline $\mathrm{CaO}$ & 9.73 & 0.46 & 0.44 & 0.16 & 9.70 & 1.49 & 0.42 & 0.13 & 9.76 & 0.42 & 9.58 & 0.85 \\
\hline $\mathrm{Na} 2 \mathrm{O}$ & 2.64 & 0.50 & 4.70 & 0.82 & 2.94 & 0.40 & 3.39 & 0.70 & 2.44 & 1.01 & 3.06 & 0.46 \\
\hline $\mathrm{K} 2 \mathrm{O}$ & 0.47 & 0.05 & 4.14 & 0.39 & 0.64 & 0.42 & 5.30 & 1.78 & 0.49 & 0.08 & 0.64 & 0.48 \\
\hline $\mathrm{P} 2 \mathrm{O5}$ & 0.30 & 0.05 & 0.02 & 0.01 & - & 0.00 & 0.01 & 0.01 & 0.53 & 0.93 & - & - \\
\hline $\mathrm{Cl}$ & - & - & - & - & - & 0.00 & - & - & - & - & - & - \\
\hline Total & 98.05 & 2.24 & 96.94 & 2.71 & 98.16 & 1.45 & 97.53 & 2.49 & 97.28 & 3.24 & 96.91 & 1.39 \\
\hline Tephra name & \multicolumn{2}{|c|}{ Saksunarvatn Ash } & \multicolumn{2}{|c|}{ Fosen Tephra } & \multicolumn{2}{|c|}{ An Druim Tephra } & \multicolumn{2}{|c|}{$\begin{array}{l}\text { The LAN1-325 } \\
\text { Tephra }\end{array}$} & \multicolumn{2}{|c|}{$\begin{array}{l}\text { The Suduroy } \\
\text { Tephra }\end{array}$} & \multicolumn{2}{|c|}{$\begin{array}{l}\text { The Breakish } \\
\text { Tephra }\end{array}$} \\
\hline $\begin{array}{l}\text { Number of sites in } \\
\text { British Isles }\end{array}$ & \multicolumn{2}{|l|}{4} & \multicolumn{2}{|l|}{1} & \multicolumn{2}{|l|}{3} & \multicolumn{2}{|l|}{1} & \multicolumn{2}{|l|}{2} & \multicolumn{2}{|l|}{1} \\
\hline $\begin{array}{l}\text { Identified outside } \\
\text { British Isles? }\end{array}$ & \multicolumn{2}{|l|}{ yes } & yes & & yes & & uncer & & yes & & no & \\
\hline $\begin{array}{l}\text { Current best age } \\
\text { estimate }\end{array}$ & 10,210 & al. BP & $\begin{array}{l}10,135 \\
\mathrm{BP}\end{array}$ & & 9648 & al. BP & $8245-$ & al. BP & $8073 \pm$ & al. BP & unkno & \\
\hline $\begin{array}{l}\text { Reference for age } \\
\text { estimate }\end{array}$ & Lohne & 2014) & Timms & 2017) & Timm & & Matth & 008) & Waste & 2002) & $\begin{array}{l}\text { Pyne- } \\
(2007\end{array}$ & \\
\hline Source & Gríms & eland & unkno & & Torfaj & eland & Torfaj & eland & Katla, & & $\begin{array}{l}\text { Askja } \\
\text { Icelan }\end{array}$ & jöll, \\
\hline
\end{tabular}




\begin{tabular}{|c|c|c|c|c|c|c|c|c|c|c|c|c|}
\hline \multirow{2}{*}{$\begin{array}{l}\text { Chemical composition } \\
\text { Major oxide (wt \%) }\end{array}$} & \multicolumn{2}{|l|}{ Basaltic } & \multicolumn{2}{|c|}{ Rhyolitic } & \multicolumn{2}{|c|}{ Rhyolitic } & \multicolumn{2}{|c|}{ Rhyolitic } & \multicolumn{2}{|c|}{ Rhyolitic } & \multicolumn{2}{|c|}{ Rhyolitic } \\
\hline & $n=106$ & $2 \sigma$ & $n=10$ & $2 \sigma$ & $n=39$ & $2 \sigma$ & $\mathrm{n}=7$ & $2 \sigma$ & $\mathrm{n}=5$ & $2 \sigma$ & $n=4$ & $2 \sigma$ \\
\hline $\mathrm{SiO} 2$ & 49.28 & 1.55 & 73.36 & 0.74 & 70.82 & 1.85 & 70.12 & 1.41 & 71.43 & 0.33 & 71.44 & 0.96 \\
\hline $\mathrm{TiO} 2$ & 3.03 & 0.51 & 0.12 & 0.01 & 0.18 & 0.06 & 0.32 & 0.03 & 0.29 & 0.03 & 0.49 & 0.02 \\
\hline $\mathrm{Al} 2 \mathrm{O} 3$ & 12.92 & 2.38 & 11.92 & 0.33 & 11.90 & 0.78 & 12.38 & 0.77 & 13.64 & 0.14 & 12.74 & 0.25 \\
\hline $\mathrm{FeO}$ & 14.13 & 1.88 & 1.52 & 0.19 & 2.79 & 0.35 & 2.16 & 0.40 & 3.82 & 0.12 & 3.59 & 0.20 \\
\hline $\mathrm{MnO}$ & 0.23 & 0.06 & 0.04 & 0.01 & 0.08 & 0.07 & 0.13 & 0.04 & 0.12 & 0.02 & 0.08 & 0.04 \\
\hline $\mathrm{MgO}$ & 5.42 & 0.96 & 0.07 & 0.06 & 0.05 & 0.04 & 0.16 & 0.04 & 0.20 & 0.02 & 0.42 & 0.04 \\
\hline $\mathrm{CaO}$ & 9.87 & 0.98 & 0.71 & 0.04 & 0.37 & 0.14 & 0.55 & 0.12 & 1.30 & 0.12 & 2.32 & 0.11 \\
\hline $\mathrm{Na} 2 \mathrm{O}$ & 2.70 & 0.56 & 4.11 & 0.29 & 5.12 & 0.44 & 4.09 & 1.03 & 5.40 & 0.27 & 3.55 & 0.17 \\
\hline $\mathrm{K} 2 \mathrm{O}$ & 0.43 & 0.16 & 3.77 & 0.25 & 4.34 & 0.23 & 3.80 & 0.51 & 3.58 & 0.20 & 2.07 & 0.06 \\
\hline P2O5 & 0.35 & 0.18 & 0.01 & 0.01 & 0.01 & 0.01 & 0.02 & 0.01 & 0.06 & 0.03 & - & - \\
\hline $\mathrm{Cl}$ & - & - & - & - & - & - & 0.12 & 0.01 & - & - & - & - \\
\hline Total & 98.39 & 2.09 & 95.62 & 1.04 & 95.64 & 2.12 & 93.95 & 1.59 & 99.77 & 0.68 & 96.67 & 1.47 \\
\hline
\end{tabular}




\section{Table 2}

List of sites in the British Isles where the Borrobol $(n=13)$, Penifiler $(n=15)$ and CRUM1 597 tephras have been proposed. Based on major and minor element analyses of glass shards, 13 sites are understood to contain the Borrobol Tephra, 15 sites the Penifiler Tephra and 2 sites the CRUM1 597 Tephra. A further 3 Borrobol, 4 Penifiler and 4 CRUM1 597 records are tentatively proposed based on stratigraphic superposition and are indicated by a ? symbol.

\begin{tabular}{|c|c|c|c|c|c|}
\hline Site & Borrobol & Penifiler & CRUM1 597 & Reference & Comment \\
\hline The Loons & $?$ & $?$ & $?$ & Callicott (2015) & $\begin{array}{l}\text { A single Borrobol-type tephra was identified and chemically analysed } \\
\text { within Windermere Interstadial sediments. It is not possible to confidently } \\
\text { propose a correlation at present. }\end{array}$ \\
\hline $\begin{array}{l}\text { Quoyloo } \\
\text { Meadow }\end{array}$ & $\mathrm{x}$ & $\mathrm{x}$ & & Timms et al. (2017) & \\
\hline $\begin{array}{l}\text { Spretta } \\
\text { Meadow }\end{array}$ & & & $\mathrm{x}$ & Timms (2016) & $\begin{array}{l}\text { A Borrobol-type tephra has been identified at the Windermere Interstadial- } \\
\text { Loch Lomond Stadial transition supporting the presence of the CRUM1 } \\
597 \text { Tephra. Importantly no older sediments with earlier Windermere } \\
\text { Interstadial tephras are present at Spretta Meadow. }\end{array}$ \\
\hline $\begin{array}{l}\text { Crudale } \\
\text { Meadow }\end{array}$ & $x$ & $x$ & $x$ & Timms et al. (2018) & Site of first discovery for the CRUM1 597 Tephra \\
\hline $\begin{array}{l}\text { Lochan An } \\
\text { Druim }\end{array}$ & & $?$ & & Ranner et al. (2005) & $\begin{array}{l}\text { A Borrobol-type tephra (S30 Tephra) was identified within Windermere } \\
\text { Interstadial deposits and dated to } 13.6 \text { cal ka BP. It is uncertain as to } \\
\text { which, if any, of the Borrobol-type tephras the S30 correlates to. }\end{array}$ \\
\hline Borrobol & $x$ & $x$ & & $\begin{array}{l}\text { Turney et al. (1997); } \\
\text { Pyne-O'Donnell } \\
\text { (2007); Lind et al. } \\
(2016)\end{array}$ & Site of first discovery for the Borrobol Tephra \\
\hline Tanera Mòr 1 & $x$ & $\mathrm{x}$ & & $\begin{array}{l}\text { Roberts (1997); } \\
\text { Roberts et al. (1998); } \\
\text { Timms (2016) }\end{array}$ & \\
\hline Tanera Mòr 2 & $\mathrm{x}$ & $\mathrm{x}$ & $?$ & Weston (2012) & $\begin{array}{l}\text { A tephra with Borrobol-type morphological properties lies at the boundary } \\
\text { between the Windermere Interstadial and the Loch Lomond Stadial } \\
\text { indicating a possible correlation with the CRUM1 } 597 \text { Tephra. }\end{array}$ \\
\hline
\end{tabular}




\begin{tabular}{|c|c|c|c|c|c|}
\hline $\begin{array}{l}\text { Eilean Fada } \\
\text { Mòr }\end{array}$ & $?$ & $?$ & $?$ & Callicott, (2013) & $\begin{array}{l}\text { Three peaks in glass shard concentration were identified within what is } \\
\text { believed to be Windermere Interstadial sediments, although part of the } \\
\text { sequence may be Dimlington in age. Shards in these peaks are typically } \\
\text { Borrobol-type in morphology i.e. Blocky, cuspate and inclusion rich. No } \\
\text { chemical analyses have been obtained to date. }\end{array}$ \\
\hline Priest Island & $x$ & $\mathrm{x}$ & & Valentine (2015) & \\
\hline Druim Loch & & $\mathrm{x}$ & & $\begin{array}{l}\text { Pyne O'Donnell } \\
(2007)\end{array}$ & Site of first discovery for the Penifiler Tephra \\
\hline Loch Ashik & $x$ & $\mathrm{x}$ & & $\begin{array}{l}\text { Pyne O'Donnell } \\
\text { (2007); Pyne } \\
\text { O'Donnell et al. } \\
\text { (2008; Brooks et al. } \\
(2012)\end{array}$ & \\
\hline $\begin{array}{l}\text { Abernethy } \\
\text { Forest }\end{array}$ & $\mathrm{x}$ & $x$ & & $\begin{array}{l}\text { Matthews et al. } \\
(2011)\end{array}$ & \\
\hline Loch Etteridge & $x$ & & $?$ & $\begin{array}{l}\text { Albert (2007); } \\
\text { Hardiman (2007); } \\
\text { Lowe et al. (2008); } \\
\text { MacLeod et al. } \\
\text { (2015) }\end{array}$ & $\begin{array}{l}\text { Glass shards positioned in the mid-Windermere Interstadial have } \\
\text { previously been correlated to the Penifiler Tephra (Lowe et al., 2008), } \\
\text { however, the major element chemistry of these does not support this } \\
\text { correlation (see Supplementary Table S2). A tephra of low concentration } \\
\text { has been noted at the Windermere Interstadial-Loch Lomond Stadial } \\
\text { transition by Albert (2007) and Hardiman (2007). Crucially the shards } \\
\text { comprising this tephra have been described as 'blocky' - characteristic of } \\
\text { the Borrobol-type series. }\end{array}$ \\
\hline Pulpit Hill & $?$ & $\mathrm{x}$ & & Lincoln (2011) & $\begin{array}{l}\text { Stratigraphic evidence (a peak in glass shard concentrations) exists for the } \\
\text { Borrobol Tephra, however, this has yet to be confirmed with chemical } \\
\text { analyses. }\end{array}$ \\
\hline $\begin{array}{l}\text { Loch an } \\
\text { t'Suidhe }\end{array}$ & $\mathrm{x}$ & $\mathrm{x}$ & $?$ & $\begin{array}{l}\text { Davies (2003); Pyne } \\
\text { O'Donnell, (2007); } \\
\text { Pyne O'Donnell et al. } \\
\text { (2008) }\end{array}$ & $\begin{array}{l}\text { The LAS-1 tephra was identified within Loch Lomond Stadial sediments by } \\
\text { Davies (2003). Unfortunately, chemical analyses returned low analytical } \\
\text { totals and a wide scatter in the data set. Whilst these analyses cannot be } \\
\text { considered completely reliable, morphological analysis reveals some } \\
\text { shards of a blocky and microlitic composition - characteristics of the } \\
\text { Borrobol-type series. }\end{array}$ \\
\hline Tirinie & & $x$ & & Candy et al. (2016) & \\
\hline $\begin{array}{l}\text { Tynaspirit } \\
\text { West }\end{array}$ & $\mathrm{x}$ & $\mathrm{x}$ & & $\begin{array}{l}\text { Turney et al. (1997); } \\
\text { Pyne O'Donnell } \\
\text { (2007); Pyne } \\
\text { O'Donnell et al. } \\
\text { (2008) }\end{array}$ & \\
\hline
\end{tabular}




\begin{tabular}{|l|l|l|l|l|}
\hline $\begin{array}{l}\text { Muir Park } \\
\text { Reservior }\end{array}$ & $\mathrm{x}$ & $\mathrm{x}$ & $\begin{array}{l}\text { Roberts (1997); } \\
\text { Cooper (1999); Lowe } \\
\text { and Roberts (2003); } \\
\text { Brooks et al. (2016) }\end{array}$ & $\begin{array}{l}\text { Turney et al. (1997); } \\
\text { Pyne O'Donnell et al. } \\
\text { (2008) }\end{array}$ \\
\hline Whitrig Bog & $\mathrm{x}$ & $\mathrm{x}$ & Williams et al. (2007) & Borrobol Tephra correlated by stratigraphy. \\
\hline Traeth Mawr & $?$ & & $\begin{array}{l}\text { A single shard of a Borrobol-type composition have been identified } \\
\text { alongside shards of the Glacier Peak and Mount St Helens J eruptions. } \\
\text { Due to stratigraphic position it is likely this shard relates to the Penifiler } \\
\text { Tephra, although this is not certain. }\end{array}$ \\
\hline Finglas River & & $?$ & Turney (1998b) &
\end{tabular}

\section{Table 3}

Sites from which glass analyses have been obtained and used to claim the presence of the 'Abernethy Tephra'. In all cases except the Glen Turret Fan record, a mixed chemical assemblage has been revealed, implicating the possibility of reworking and amalgamation of older tephra deposits.

\begin{tabular}{|c|c|c|c|c|c|c|}
\hline Site & $\begin{array}{l}\text { n.o. of analyses } \\
\text { obtained }\end{array}$ & $\%$ Katla-type & $\%$ Borrobol-type & $\%$ Other & $\begin{array}{l}\text { Abernethy Tephra } \\
\text { declared present }\end{array}$ & Reference \\
\hline $\begin{array}{l}\text { Abernethy } \\
\text { Forest }\end{array}$ & 12 & 83 & 17 & 0 & Yes & Matthews et al. (2011) \\
\hline $\begin{array}{l}\text { Loch } \\
\text { Etteridge }\end{array}$ & 20 & 70 & 30 & 0 & Yes & MacLeod et al. (2015) \\
\hline $\begin{array}{l}\text { Glen Turret } \\
\text { Fan }\end{array}$ & 4 & 100 & 0 & 0 & Yes & MacLeod et al. (2015) \\
\hline Kingshouse 2 & 8 & 63 & 0 & 37 & Yes & Lowe et al. (in prep) \\
\hline $\begin{array}{l}\text { Crudale } \\
\text { Meadow }\end{array}$ & 12 & 42 & 50 & 8 & No & Timms et al. (2018) \\
\hline Tanera Mòr & 35 & 89 & 11 & 0 & No & Timms (2016) \\
\hline
\end{tabular}




\section{Table 4}

Summary of tephra isochrons included, and those not yet considered suitable for inclusion, within the British Isles tephrostratigraphic scheme (c. 16-8 ka BP). Also shown are reference records for each tephra; these are the sites in the British Isles which each tephra is currently best represented at. Categories $\mathrm{i}$, ii and iii are explained in the text.

\begin{tabular}{|c|c|c|c|c|c|c|}
\hline \multicolumn{7}{|c|}{ Tephras included within the British Isles tephrostratigraphic framework } \\
\hline Tephra & Category & Age estimate & $\begin{array}{l}\text { British Isles } \\
\text { reference site }\end{array}$ & $\begin{array}{l}\text { Reference } \\
\text { source } \\
\text { publication }\end{array}$ & Sites identified & $\begin{array}{l}\text { Identified } \\
\text { outside } \\
\text { the } \\
\text { British } \\
\text { Isles? }\end{array}$ \\
\hline Dimna Ash & $\mathrm{ii}$ & $\begin{array}{l}15,100 \pm 300 \\
\text { cal. } \mathrm{BP}\end{array}$ & Tanera Mòr 2 & Weston (2012) & Tanera Mòr 1, Tanera Mòr 2, Priest Island & yes \\
\hline $\begin{array}{l}\text { Tanera } \\
\text { Tephra }\end{array}$ & ii & unknown & Tanera Mòr 1 & Timms (2016) & Quoyloo Meadow, Tanera Mòr 1, Priest Island & uncertain \\
\hline $\begin{array}{l}\text { Borrobol } \\
\text { Tephra }\end{array}$ & i & $\begin{array}{l}14,098 \pm 94 \\
\text { cal. BP }\end{array}$ & $\begin{array}{l}\text { Abernethy } \\
\text { Forest }\end{array}$ & $\begin{array}{l}\text { Matthews et al. } \\
(2011)\end{array}$ & $\begin{array}{l}\text { Quoyloo Meadow, Crudale Meadow, Borrobol, Tanera } \\
\text { Mòr 1, Tanera Mòr 2, Priest Island, Loch Ashik, } \\
\text { Abernethy Forest, Loch Etteridge, Loch an t'Suidhe, } \\
\text { Tynaspirit West, Muir Park Reservior, Whitrig Bog }\end{array}$ & yes \\
\hline $\begin{array}{l}\text { Penifiler } \\
\text { Tephra }\end{array}$ & $\mathrm{ii}$ & $\begin{array}{l}13,939 \pm 132 \\
\text { cal. BP }\end{array}$ & Tirinie & $\begin{array}{l}\text { Candy et al. } \\
(2016)\end{array}$ & $\begin{array}{l}\text { Quoyloo Meadow, Crudale Meadow, Borrobol, Tanera } \\
\text { Mòr 1, Tanera Mòr 2, Priest Island, Druim Loch, Loch } \\
\text { Ashik, Abernethy Forest, Tirinie, Pulpit Hill, Loch an } \\
\text { t'Suidhe, Tynaspirit West, Muir Park Reservior, Whitrig } \\
\text { Bog }\end{array}$ & uncertain \\
\hline $\begin{array}{l}\text { Glacier Peak } \\
\text { G \& B }\end{array}$ & $\mathrm{ii}$ & $\begin{array}{l}13,710-13,410 \\
\text { cal. BP }\end{array}$ & Finglas River & this study & Finglas River, Loch Ashik & yes \\
\hline Vedde Ash & $\mathrm{i}$ & $\begin{array}{l}12,023 \pm 86 \\
\text { cal. BP }\end{array}$ & Loch Ashik & $\begin{array}{l}\text { Davies et al. } \\
\text { (2001); Pyne- } \\
\text { O'Donnell } \\
(2011)\end{array}$ & $\begin{array}{l}\text { The Loons, Quoyloo Meadow, Crudale Meadow, Spretta } \\
\text { Meadow, Lochan An Druim, Borrobol, Tanera Mòr 1, } \\
\text { Tanera Mòr 2, Priest Island, Loch Ashik, Kennethmont, } \\
\text { Abernethy Forest, Loch Etteridge, Mishnish, Tirinie, } \\
\text { Pulpit Hill, Loch an t'Suidhe, Tynaspirit West, Inches } \\
\text { (Lake of Menteith), Muir Park Reservior, Howburn Farm, } \\
\text { Whitrig Bog, Palaeolake Flixton }\end{array}$ & yes \\
\hline Abernethy & $\mathrm{ii}$ & $11,462 \pm 144$ & Abernethy & Matthews et al. & Abernethy Forest, Loch Etteridge, Glen Turret Fan, & yes \\
\hline
\end{tabular}




\begin{tabular}{|c|c|c|c|c|c|c|}
\hline Tephra & & cal. BP & Forest & $(2011)$ & Kingshouse 2 & \\
\hline $\begin{array}{l}\text { Hässeldalen } \\
\text { Tephra }\end{array}$ & i & $\begin{array}{l}11,316 \pm 124 \\
\text { cal. BP }\end{array}$ & $\begin{array}{l}\text { Crudale } \\
\text { Meadow }\end{array}$ & $\begin{array}{l}\text { Timms et al. } \\
(2018)\end{array}$ & Quoyloo Meadow, Crudale Meadow, Kingshouse 2 & yes \\
\hline $\begin{array}{l}\text { Askja-S } \\
\text { Tephra }\end{array}$ & i & $\begin{array}{l}10,830 \pm 114 \\
\text { cal. BP }\end{array}$ & $\begin{array}{l}\text { Crudale } \\
\text { Meadow }\end{array}$ & $\begin{array}{l}\text { Timms et al. } \\
(2018)\end{array}$ & $\begin{array}{l}\text { Quoyloo Meadow, Crudale Meadow, Tanera Mòr 1, } \\
\text { Loch Ashik, Glen Turret Bank, Inverlair, Kingshouse 2, } \\
\text { Pant-y-Llyn, Lough Nadourcan, Long Lough }\end{array}$ & yes \\
\hline Ashik Tephra & ii & $\begin{array}{l}10,716 \pm 230 \\
\text { cal. BP }\end{array}$ & Loch Ashik & $\begin{array}{l}\text { Pyne-O'Donnell } \\
\text { (2007) }\end{array}$ & Quoyloo Meadow, Druim Loch, Loch Ashik & no \\
\hline $\begin{array}{l}\text { Saksunarvat } \\
\text { n 10-ka } \\
\text { series (Havn- } \\
3 / 4 \text { ) }\end{array}$ & ii & $\begin{array}{l}\sim 10.37 \text { and } \\
\sim 10.3 \text { ka BP }\end{array}$ & Loch Ashik & $\begin{array}{l}\text { Pyne-O'Donnell } \\
(2007)\end{array}$ & Loch Ashik & yes \\
\hline $\begin{array}{l}\text { Saksunarvat } \\
\text { n 10-ka } \\
\text { series } \\
\text { (Saksunarvat } \\
\text { n Ash sensu } \\
\text { stricto) }\end{array}$ & ii & $\begin{array}{l}10,210 \pm 35 \\
\text { cal. BP }\end{array}$ & $\begin{array}{l}\text { Crudale } \\
\text { Meadow }\end{array}$ & $\begin{array}{l}\text { Timms et al. } \\
(2018)\end{array}$ & $\begin{array}{l}\text { Dallican Water, Loch of Benston, Quoyloo Meadow, } \\
\text { Crudale Meadow }\end{array}$ & yes \\
\hline $\begin{array}{l}\text { Fosen } \\
\text { Tephra }\end{array}$ & $\mathrm{i}$ & $\begin{array}{l}10,139 \pm 116 \\
\text { cal. BP }\end{array}$ & $\begin{array}{l}\text { Quoyloo } \\
\text { Meadow }\end{array}$ & $\begin{array}{l}\text { Timms et al. } \\
\text { (2017) }\end{array}$ & Quoyloo Meadow & yes \\
\hline $\begin{array}{l}\text { An Druim } \\
\text { Tephra }\end{array}$ & i & $\begin{array}{l}9648 \pm 158 \mathrm{cal} \\
. \mathrm{BP}\end{array}$ & $\begin{array}{l}\text { Lochan An } \\
\text { Druim }\end{array}$ & $\begin{array}{l}\text { Ranner et al. } \\
(2005)\end{array}$ & Quoyloo Meadow, Lochan An Druim, Inverlair & yes \\
\hline $\begin{array}{l}\text { Suduroy } \\
\text { Tephra }\end{array}$ & ii & $\begin{array}{l}8073 \pm 192 \\
\text { cal. BP }\end{array}$ & $\begin{array}{l}\text { Loch Laggan } \\
\text { East }\end{array}$ & MacLeod (2008) & Loch Laggan East, Rubha Port an t-Seilich & yes \\
\hline \multicolumn{7}{|c|}{ Tephras not yet included within the British Isles tephrostratigraphic framework } \\
\hline CRUM1 676 & iii & unknown & $\begin{array}{l}\text { Crudale } \\
\text { Meadow }\end{array}$ & $\begin{array}{l}\text { Timms et al. } \\
\text { (2018) }\end{array}$ & Crudale Meadow & no \\
\hline $\begin{array}{l}\text { Mount St } \\
\text { Helens J }\end{array}$ & iii & $\begin{array}{l}13.860-12.800 \\
\text { cal. BP }\end{array}$ & Finglas River & $\begin{array}{l}\text { Turney (1998b); } \\
\text { this study }\end{array}$ & Finglas River & yes \\
\hline $\begin{array}{l}\text { Roddans Port } \\
\text { A }\end{array}$ & iii & unknown & Roddans Port & $\begin{array}{l}\text { Turney et al. } \\
(2006)\end{array}$ & Roddans Port & no \\
\hline $\begin{array}{l}\text { Roddans Port } \\
\text { B }\end{array}$ & iii & unknown & Roddans Port & $\begin{array}{l}\text { Turney et al. } \\
\text { (2006) }\end{array}$ & Roddans Port & no \\
\hline CRUM1 597 & iii & $\begin{array}{l}12,457 \pm 896 \\
\text { cal. BP }\end{array}$ & $\begin{array}{l}\text { Crudale } \\
\text { Meadow }\end{array}$ & $\begin{array}{l}\text { Timms et al. } \\
(2018)\end{array}$ & Crudale Meadow, Spretta Meadow & no \\
\hline Crudale & iii & c. $12,111-$ & Crudale & Timms et al. & Crudale Meadow, Tynaspirit West & uncertain \\
\hline
\end{tabular}




\begin{tabular}{|l|l|l|l|l|l|}
\hline Tephra & & $\begin{array}{l}11,174 \text { cal. BP } \\
\text { Meadow }\end{array}$ & $(2018)$ & Crudale Meadow \\
\hline $\begin{array}{l}\text { CRUM1 510 } \\
\text { Tephra }\end{array}$ & iii & $\begin{array}{l}10,837 \pm 148 \\
\text { cal. BP }\end{array}$ & $\begin{array}{l}\text { Crudale } \\
\text { Meadow }\end{array}$ & $\begin{array}{l}\text { Timms et al. } \\
(2018)\end{array}$ & no \\
\hline $\begin{array}{l}\text { Hovsdalur } \\
\text { Tephra }\end{array}$ & iii & $\begin{array}{l}\text { Timms et al. BP } \\
(2017)\end{array}$ & $\begin{array}{l}\text { Quoyloo } \\
\text { Meadow }\end{array}$ & $\begin{array}{l}\text { Timms et al. } \\
(2018)\end{array}$ & yes \\
\hline $\begin{array}{l}\text { Saksunarvatn } \\
\text { 10-ka series } \\
\text { (CRUM1 444) }\end{array}$ & iii & $\begin{array}{l}10,476 \pm 254 \\
\text { cal. BP }\end{array}$ & $\begin{array}{l}\text { Crudale } \\
\text { Meadow }\end{array}$ & uncertain \\
\hline $\begin{array}{l}\text { Breakish } \\
\text { Tephra }\end{array}$ & iii & unknown & Loch Ashik & $\begin{array}{l}\text { Pyne-O'Donnell } \\
(2007)\end{array}$ & Loch Ashik \\
\hline $\begin{array}{l}\text { LAN1-325 } \\
\text { Breakish } \\
\text { Tephra }\end{array}$ & iii & $\begin{array}{l}8245-8041 \text { cal. } \\
\text { BP }\end{array}$ & $\begin{array}{l}\text { Loughanascadd } \\
\text { y crannog }\end{array}$ & Matthews (2008) & Loughanascaddy crannog \\
\hline
\end{tabular}




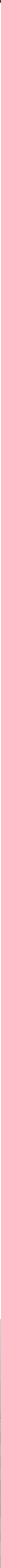

